PAULA NUNES MAMEDE ROSA

\title{
A FUNÇÃO RESSOCIALIZADORA DA PENA E O PODER JUDICIÁRIO: ENCARCERAMENTO EM MASSA E RESPONSABILIDADE ESTATAL
}

\author{
Dissertação de Mestrado \\ ORIENTADORA: PROFESSORA ASSOCIADA DOUTORA MARIÂNGELA \\ GAMA DE MAGALHÃES GOMES
}

UNIVERSIDADE DE SÃO PAULO

FACULDADE DE DIREITO

São Paulo-SP 

PAULA NUNES MAMEDE ROSA

\section{A FUNÇÃO RESSOCIALIZADORA DA PENA E O PODER JUDICIÁRIO: ENCARCERAMENTO EM MASSA E RESPONSABILIDADE ESTATAL}

Dissertação apresentada à Banca Examinadora do Programa de Pós-Graduação em Direito, da Faculdade de Direito da Universidade de São Paulo, como exigência parcial para obtenção do título de Mestre em Direito, na área de concentração Direito Penal, Medicina Forense e Criminologia, sob a orientação da Professora Associada Doutora Mariângela Gama de Magalhães Gomes.

\section{UNIVERSIDADE DE SÃO PAULO}

FACULDADE DE DIREITO

São Paulo-SP 
ROSA, Paula Nunes Mamede

A função ressocializadora da pena e o Poder Judiciário: encarceramento em massa e responsabilidade estatal / Paula Nunes Mamede ROSA ; orientadora Mariângela Gama de Magalhães GOMES -- São Paulo, 2017.

$327 \mathrm{f}$.

Dissertação (Mestrado - Programa de Pós-Graduação em Direito Penal, Medicina Forense e Criminologia) Faculdade de Direito, Universidade de São Paulo, 2017 .

1. pesquisa empírica em direito. 2. função ressocializadora. 3. Poder Judiciário. 4. jurisprudência. 5. encarceramento em massa. I. GOMES, Mariângela Gama de Magalhães, orient. II. Título. 
Nome: ROSA, Paula Nunes Mamede.

Título: A função ressocializadora da pena e o Poder Judiciário: encarceramento em massa e responsabilidade estatal

Dissertação apresentada à Banca Examinadora do Programa de Pós-Graduação em Direito, da Faculdade de Direito da Universidade de São Paulo, como exigência parcial para obtenção do título de Mestre em Direito, na área de concentração Direito Penal, Medicina Forense e Criminologia, sob a orientação da Professora Associada Doutora Mariângela Gama de Magalhães Gomes.

Aprovada em:

\author{
Banca Examinadora
}

Prof. Dr. Instituiçãa

Julgamento Assinatura

Prof. Dr. Instituição

Julgamento Assinatura

Prof. Dr. Instituição Assinatura 

Aos meus avós, Ilza Rosa, José Nunes e José Rosa, in memoriam, e Sara Mamede. 



\section{AGRADECIMENTOS}

Agradeço à Professora Mariângela, por ter me dado a oportunidade de realizar esse Mestrado sob sua supervisão, pela paciência e auxílio, pela orientação detalhada do trabalho, além dos ensinamentos adjacentes à dissertação, permitindo um contato constante com os outros aspectos da vida acadêmica.

À Professora Helena Regina Lobo da Costa e ao Professor Alamiro Velludo Salvador Netto, pelas sugestões e questionamentos na banca de qualificação, que foram decisivas para moldar o trabalho final.

Ao Professor Salomão Shecaira, pela amizade e pelo apoio, desde a criação de uma lista de livros "que todo criminalista deve ler", antes de ingressar na pós, até o final desse processo todo. E também ao Departamento de Direito Penal, tanto os funcionários - Dalva e Marcela -, que são parte indispensável de todo o trabalho realizado, quanto os Professores, responsáveis por um ambiente acolhedor e estimulante aos alunos.

Aos colegas e companheiros da pós, que tornaram essa jornada mais leve, pelas cervejas e happy hours, discussões em sala de aula (e fora delas), troca de materiais, revisões de textos, mensagens de boa sorte nas bancas, pelas angústias compartilhadas, enfim, pela amizade. Especialmente, devo citar o Ian Matozo Especiato, por tudo envolvido na nossa parceria esses 03 anos, a Marcela Diorio, desde os tempos de aluna especial, e José Paulo Naves.

Aos meus chefes à época do processo seletivo, que me apoiaram e estimularam, Rogério Taffarello e Pedro Andrade, sempre na torcida, e aos que vieram depois, pela compreensão e apoio, Fernanda Gomes, Amaro Thomé, Lucelene Cruz, Airton Vieira e Juliana Morais Bicudo.

Aos meus amigos de fora do ambiente acadêmico, por reclamarem da minha ausência, me obrigarem a relaxar de vez em quando e me receberem sempre de braços abertos.

Agradeço aos meus irmãos, Henrique e Fernanda, pelo lar que criamos juntos, pela paciência com a bagunça de textos, livros, computadores etc, pelo apoio nos momentos difíceis e por me aguentarem nos momentos de estresse, além de me forçarem a acordar nos dias de maior esgotamento.

Acima de tudo, aos meus pais, Adalberto e Maria Luiza, pelas oportunidades, pela insistência na importância dos estudos, pelo exemplo do que é fazer pesquisa de forma 
séria, além de me mostrarem diariamente um imensurável amor pela vida acadêmica. Vocês são a minha inspiração. 


\section{RESUMO}

ROSA, Paula Nunes Mamede. A função ressocializadora da pena e o Poder Judiciário: encarceramento em massa e responsabilidade estatal. 2017. 327 f. Dissertação (Mestrado em Direito Penal) - Faculdade de Direito da Universidade de São Paulo, São Paulo. 2017.

$\mathrm{O}$ presente trabalho visa a identificar quais as principais linhas argumentativas utilizadas pelo Tribunal de Justiça de São Paulo acerca da função ressocializadora da pena. Para tanto, foi realizada pesquisa empírica que consistiu no levantamento e na análise de 400 acórdãos da Corte Paulista no âmbito da execução penal. Para o embasamento da pesquisa qualitativa, foram expostas as principais críticas sobre a pena de prisão e essa sua finalidade declarada, bem como a sua utilização como fundamento para um discurso de humanização das prisões. Foi analisada, ainda, a importância da jurisprudência e da atividade jurisdicional para a conformação do Direito e para a concretização da função ressocializadora da pena. Buscando traçar uma concepção dessa finalidade à luz da Constituição Federal e da garantia dos direitos fundamentais, que envolvem os direitos individuais e sociais, chegou-se à conclusão de que tal concepção implica a responsabilidade estatal pelo fornecimento de condições materiais para a devida reintegração do sentenciado e a limitação de seu poder punitivo pelos direitos individuais, não se sustentando mais aquela concepção de ressocialização que justifica a intervenção na individualidade e intimidade das pessoas, mesmo quando condenadas pelo cometimento de um delito. O que se verificou da análise dos acórdãos, no entanto, foi a rara preocupação de fato com o fornecimento dessas condições materiais e a utilização discursiva da função ressocializadora somente como pretexto justificador da pena de prisão. Os direitos individuais e a preservação da autodeterminação dos sentenciados, por sua vez, foram observados em acórdãos que adotavam o princípio da legalidade. Por outro lado, constatou-se que ainda predominam, no âmbito da execução penal, ideias e concepções típicas do positivismo italiano e ao sentenciado não são observados os mesmos direitos fundamentais que ao resto da população, sendo o cumprimento de pena permeado de categorias como "personalidade do agente" e "periculosidade", prevalecendo uma função de neutralização do indivíduo e a atividade jurisdicional como garantidora da segurança pública.

Palavras-Chave: pesquisa empírica em direito; função ressocializadora; Poder Judiciário; jurisprudência; encarceramento em massa. 



\begin{abstract}
ROSA, Paula Nunes Mamede. The rehabilitative function of the penalty and the Judicial Power: mass incarceration and state responsibility. 2017. $327 \mathrm{f}$. Dissertation (Masters in Criminal Law) - Faculty of Law, University of São Paulo, São Paulo. 2017.

This study aims to identify the main argumentative lines adopted by the São Paulo State Court of Appeals on the rehabilitative function of the penalty. To this purpose, an empirical research was conducted to analyse 400 decisions by the mentioned Court, in the area of sentence execution. As a basis for the qualitative research, the main aspects of the criticism made to the prison penalty and its stated rehabilitative purpose, as well as the use of this function as basis for a discourse on prison reform, were exposed. The importance of case law and judicial activity to the conformation of the law and to the achievement of the rehabilitative function were also analyzed. On the attempt to draw a conception of that purpose according to the Constitution and the need to guarantee fundamental rights, which involves individual and social rights, the conclusion was that this conception implies state responsibility for providing material conditions for the proper reintegration of the convict, while the punitive power is limited by individual rights, and, therefore, it is not possible to sustain rehabilitation as a purpose that tries to intervene in people's individuality and intimacy, even if the person is convicted for a criminal offense. What we found from the analysis of the judicial decisions, however, was that few of them were concerned with actually supplying these material conditions, showing that the rehabilitative function remains existing only in the discourse that justifies imprisonment. Individual rights and the preservation of self-determination of convicts were observed in judgments that adopted the principle of legality. On the other hand, it was found that in the criminal execution are still predominant typical ideas and concepts of Italian positivism and the fundamental rights are not guaranteed to the same extenct as to the rest of the population, and the criminal execution is filled with categories such as "agent's personality" and "dangerousness", prevailing the purpose of neutralizing the individual and judicial activity as guarantor of public safety.
\end{abstract}

Keywords: empirical legal research; rehabilitative function; Judicial Power; judicial decisions; mass incarceration. 



\section{SUMÁRIO}

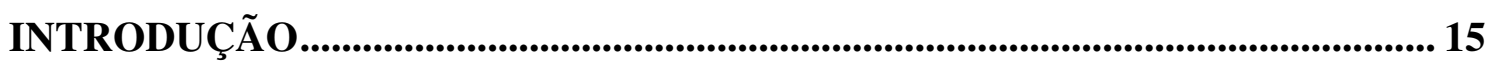

CAPÍTULO 01 - A FUNÇÃO RESSOCIALIZADORA DA PENA.......................... 23

1.1 Introdução: as teorias que buscam justificar a pena........................................... 23

1.2 As críticas à ressocialização na execução penal .................................................. 27

1.3 As tentativas ressocializadoras como esforços para a humanização da pena........ 37

1.3.1 Introdução ao pensamento ressocializador...................................................... 37

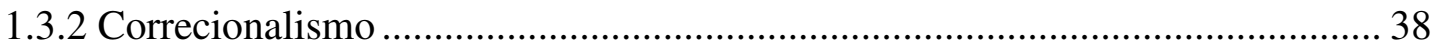

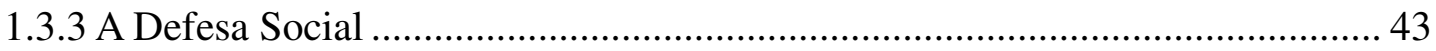

1.3.4 A Lei de Execução Penal............................................................................. 51

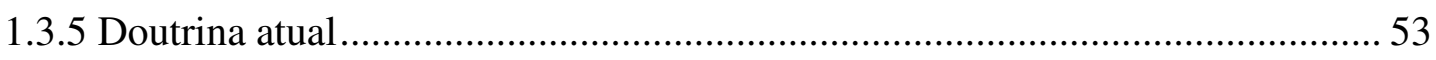

1.4 A função ressocializadora: conteúdo em debate................................................ 58

1.5 Institutos utilizados na Execução Penal para a ressocialização do preso............... 62

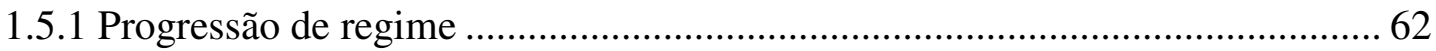

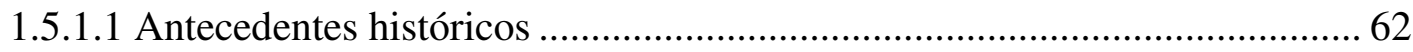

1.5.1.2 A progressão de regime na atual legislação brasileira ................................ 66

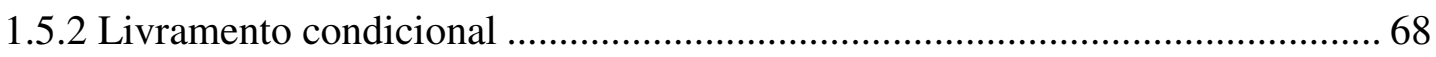

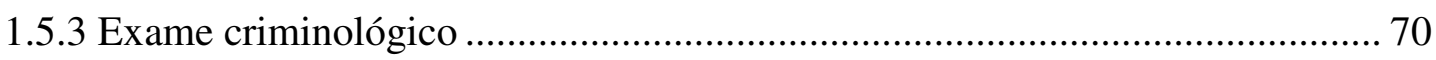

CAPÍTULO 02 - O PAPEL DO PODER JUDICIÁRIO NO ESTADO DE DIREITO

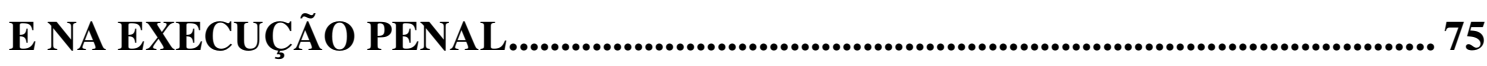

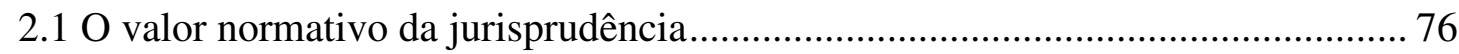

$2.2 \mathrm{O}$ crescimento do espaço de criatividade do juiz e as normas programáticas....... 82

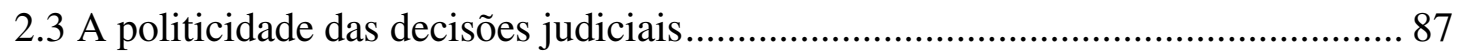

2.4 A decisão judicial na teoria de Pierre Bourdieu .................................................... 90

2.5 O Poder Judiciário na Execução Penal.................................................................. 96

2.5.1 A jurisdicionalização da Execução Penal ......................................................... 97

2.5.2 A Constituição Federal como guia para a atuação do juiz na execução penal.104

CAPÍtULO 03 - AS CARACTERÍSTICAS DA PESQUISA EMPÍRICA

REALIZADA .......................................................................................................................... 107

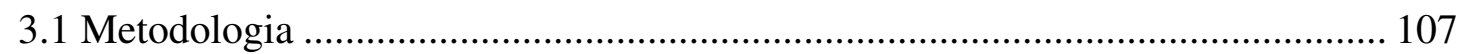

3.1.1 A opção pela pesquisa qualitativa ............................................................ 107 
3.1.2 Critérios de pesquisa e montagem da amostra ............................................ 110

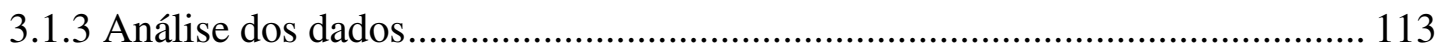

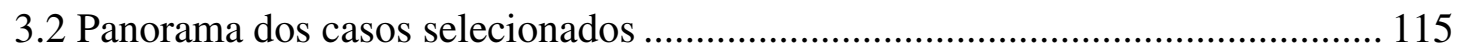

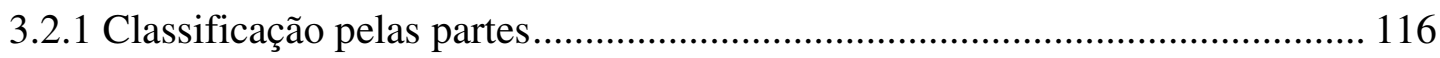

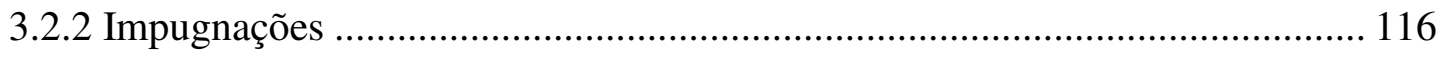

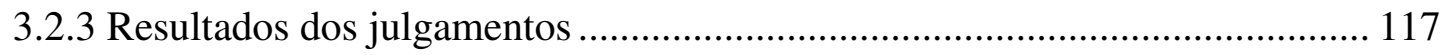

3.2.4 Argumentos ministeriais e defensivos ...................................................... 120

3.2.4.1 Argumentos do Ministério Público............................................................ 121

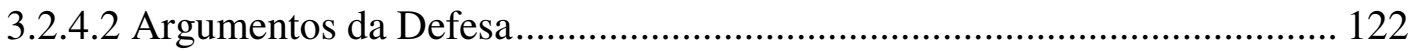

CAPÍTULO 04 - PESQUISA QUALITATIVA................................................. 125

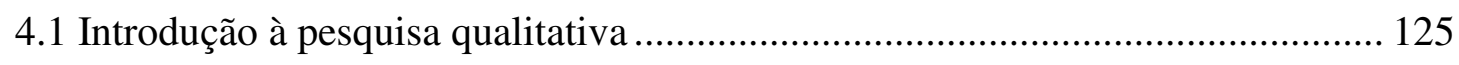

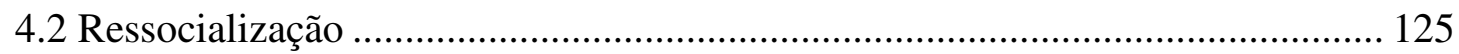

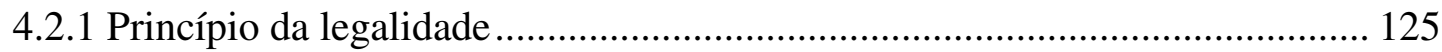

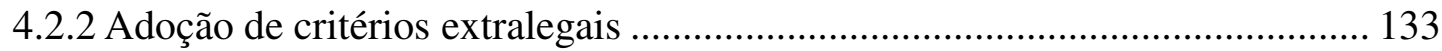

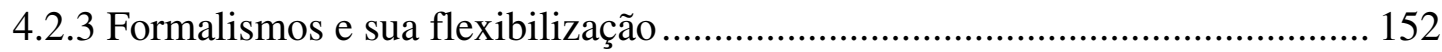

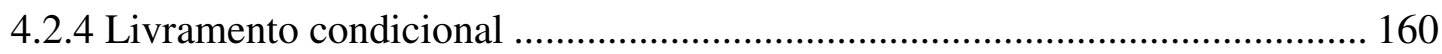

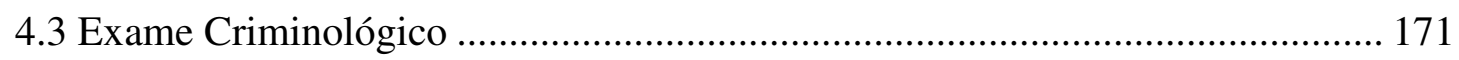

4.3.1 A realização do exame criminológico......................................................... 171

4.3.2 A utilização do exame criminológico e de seu conteúdo ................................ 189

4.3.3 Categorias utilizadas no exame criminológico ............................................. 204

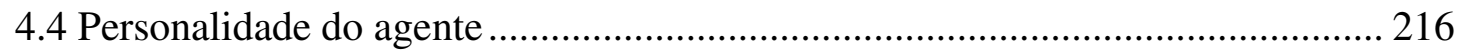

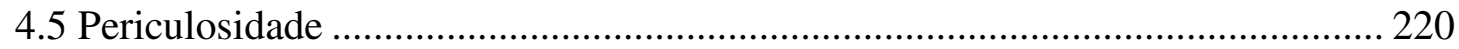

4.6 Gravidade do delito e pena a cumprir .............................................................. 229

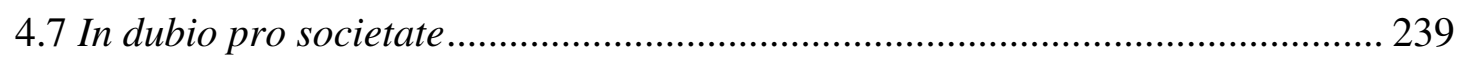

4.8 Argumentos relacionados à atividade jurisdicional.......................................... 250

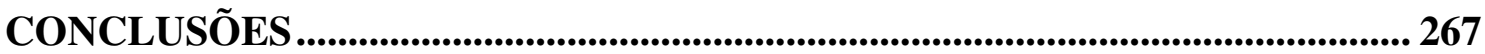

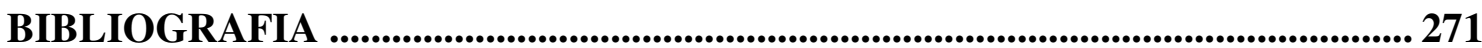

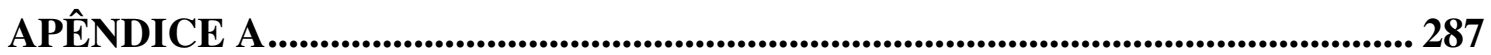

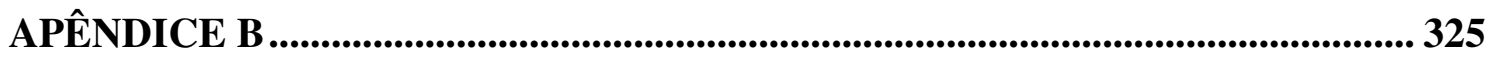




\section{INTRODUÇÃO}

O encarceramento em massa é uma das grandes violações de Direitos Humanos no Brasil, principalmente pela insuficiência de vagas e investimentos realizados nos estabelecimentos prisionais. De acordo com o Levantamento Nacional de Informações Penitenciárias de 2014, o Brasil contava, em junho de 2014, com 607.731 pessoas privadas de liberdade, em um espaço correspondente a 376.669 vagas, o que significa um déficit de 231.062 vagas e uma taxa de ocupação de $161 \%^{1}$. Além disso, verificou-se que a proporção de pessoas soropositivas dentre os presos é 60 vezes maior do que a proporção na população brasileira total, enquanto a taxa de tuberculose é 38 vezes menor na população livre ${ }^{2}$. A mortalidade dentro das unidades prisionais - considerando-se as mortes intencionais - é seis vezes maior do que a taxa de crimes letais intencionais verificada no Brasil $^{3}$.

Dessa forma, uma pessoa, quando é presa no Brasil, tem não apenas a sua liberdade privada - e todos os danos decorrentes dessa privação, como afastamento da família, do círculo social e da sua comunidade -, mas é submetida a um ambiente que viola a sua integridade física, emocional e até a sua vida. E tudo isso enquanto sob custódia do Estado, o mesmo que prevê a pena, aplica-a e a administra.

Em visita realizada ao Brasil em 2011, o Subcomitê para a Prevenção da Tortura da Organização das Nações Unidas, assinalou que várias recomendações que já haviam sido feitas por diversos mecanismos da Organização das Nações Unidas não haviam sido implementadas, sendo constatados diversos problemas que se mantinham desde visitas anteriores ${ }^{4}$. Atentaram-se para a falta de assistência médica nos estabelecimentos visitados,

${ }^{1}$ DEPARTAMENTO PENITENCIÁRIO NACIONAL - MINISTÉRIO DA JUSTIÇA. Levantamento Nacional de Informações Penitenciárias - Infopen - Junho de 2014. Brasília, DF, 2014, p. 11. Disponível em: http://www.justica.gov.br/noticias/mj-divulgara-novo-relatorio-do-infopen-nesta-terca-feira/relatoriodepen-versao-web.pdf. Acesso em: 02 out. 2016.

${ }^{2}$ DEPARTAMENTO PENITENCIÁRIO NACIONAL - MINISTÉRIO DA JUSTIÇA. Levantamento Nacional de Informações Penitenciárias - Infopen - Junho de 2014. Brasília, DF, 2014, p. 114. Disponível em: http://www.justica.gov.br/noticias/mj-divulgara-novo-relatorio-do-infopen-nesta-terca-feira/relatoriodepen-versao-web.pdf. Acesso em: 02 out. 2016.

3 DEPARTAMENTO PENITENCIÁRIO NACIONAL - MINISTÉRIO DA JUSTIÇA. Levantamento Nacional de Informações Penitenciárias - Infopen - Junho de 2014. Brasília, DF, 2014, p. 115. Disponível em: http://www.justica.gov.br/noticias/mj-divulgara-novo-relatorio-do-infopen-nesta-terca-feira/relatoriodepen-versao-web.pdf. Acesso em: 02 out. 2016.

${ }^{4}$ ORGANIZAÇÃO DAS NAÇÕES UNIDAS. Informe sobre la visita al Brasil del Subcomité para la Prevención de La Tortura y Otros Tratos o Penas Crueles, Inhumanos o Degradantes. Geneva, Suiça, 2012, 
havendo casos de reclusos com enfermidades crônicas graves, fraturas ou lesões que não recebiam tratamento, além de terem expressado reticência em solicitar assistência médica, pois havia experiências de castigos infligidos por agentes penitenciários ou maus tratos durante o traslado para o hospital ${ }^{5}$.

Além disso, apontaram a impunidade para os casos de tortura por funcionários públicos, bem como verificaram, com preocupação, diversas denúncias quanto a casos de corrupção no sistema prisional, como, por exemplo, casos em que os presos deveriam pagar propina para ter acesso a necessidades básicas garantidas por lei, como as saídas ao ar livre, visitas de familiares e proteção, e até casos em que pessoas detidas eram negligenciadas nas dependências policiais, tendo que subornar agentes estatais para que fossem levadas a estabelecimentos prisionais. ${ }^{6}$

Nesse mesmo relatório, fizeram recomendações quanto à garantia dos direitos quando do momento da detenção, como conhecer seus direitos e informar um terceiro sobre a detenção, ou mesmo observar a classificação e separação dos presos ${ }^{7}$. Também foram dirigidas críticas e sugestões à superlotação verificada, falta de condições materiais, como celas sujas e sem ventilação, sem saneamento ou com saneamento inadequado, sem roupas de cama ou insuficientes, bem como falta de alimentos, água ou acesso ao ar livre e exercício ${ }^{8}$.

Ao longo da fiscalização realizada, ainda, receberam denúncias de tortura e maus tratos no momento da detenção e durante a custódia policial, que envolviam espancamento, ameaças, privação de comida e água, obrigação de manter posições forçadas, afogamentos,

p. 4. Disponível em: http://acnudh.org/wp-content/uploads/2012/09/OPCAT-Brasil1.pdf. Acesso em: 16 set. 2016.

${ }^{5}$ ORGANIZAÇÃO DAS NAÇÕES UNIDAS. Informe sobre la visita al Brasil del Subcomité para la Prevención de La Tortura y Otros Tratos o Penas Crueles, Inhumanos o Degradantes. Geneva, Suiça, 2012, p. 8-9. Disponível em: http://acnudh.org/wp-content/uploads/2012/09/OPCAT-Brasil1.pdf. Acesso em: 16 set. 2016.

${ }^{6}$ ORGANIZAÇÃO DAS NAÇÕES UNIDAS. Informe sobre la visita al Brasil del Subcomité para la Prevención de La Tortura y Otros Tratos o Penas Crueles, Inhumanos o Degradantes. Geneva, Suiça, 2012, p. 10-11. Disponível em: http://acnudh.org/wp-content/uploads/2012/09/OPCAT-Brasil1.pdf. Acesso em: 16 set. 2016.

${ }^{7}$ ORGANIZAÇÃO DAS NAÇÕES UNIDAS. Informe sobre la visita al Brasil del Subcomité para la Prevención de La Tortura y Otros Tratos o Penas Crueles, Inhumanos o Degradantes. Geneva, Suiça, 2012, p. 12-13. Disponível em: http://acnudh.org/wp-content/uploads/2012/09/OPCAT-Brasill.pdf. Acesso em: 16 set. 2016.

${ }^{8}$ ORGANIZAÇÃO DAS NAÇÕES UNIDAS. Informe sobre la visita al Brasil del Subcomité para la Prevención de La Tortura y Otros Tratos o Penas Crueles, Inhumanos o Degradantes. Geneva, Suiça, 2012, p. 14. Disponível em: http://acnudh.org/wp-content/uploads/2012/09/OPCAT-Brasil1.pdf. Acesso em: 16 set. 2016. 
descargas elétricas, duchas geladas e até estupro 9 . O mesmo ocorria quando os detidos já estavam nos estabelecimentos prisionais, havendo denúncias de espancamentos, insultos, ameaças, sanções arbitrárias, humilhações e até uso de gás lacrimogêneo dentro das celas $^{10}$.

Foram verificadas, ainda, as más condições carcerárias, como a superlotação, falta de condições materiais como colchões, tempo para exercício físico, saídas ao ar livre, fiscalização extremadas dos presos (preocupando-se com as sequelas psicológicas que podem originar), casos de morte dentro dos estabelecimentos prisionais e a falta de registros sobre a causa de tais mortes, falta de água quente para os banhos, celas escuras, sujas e infestadas de insetos e baratas, deficiências quanto ao fornecimento de artigos de higiene como sabonetes e papel higiênico, falta de atividades educacionais e laborterápicas, acesso limitado a comunicações com o mundo exterior, revistas vexatórias e má qualidade dos alimentos ${ }^{11}$.

Nesse contexto de violações de direitos humanos - devido à superpopulação carcerária, violência entre detentos e entre estes e agentes penitenciários, tortura, maus tratos, abusos e desrespeito a condições mínimas de sobrevivência -, surgiram questionamentos acerca de como o Estado se posiciona diante desse problema e da sua responsabilidade por tais violações, emergindo, assim, uma proposta de pesquisa.

Pelos dados acima expostos, fica evidente a inércia do Poder Executivo no fornecimento de condições materiais para o devido cumprimento de pena.

No plano legislativo, se por um lado vislumbra-se algumas tentativas de se reduzir a utilização do Direito Penal e da prisão, como com a previsão de penas substitutivas da privação de liberdade (introduzidas pela Reforma da Parte Geral do Código Penal de 1984, mas ampliadas pela Lei n. 9.714/1998) ou mesmo a edição da Lei n. 9.099/1995 - que prevê novos modelos despenalizadores para conciliação de conflitos -, por outro observa-

\footnotetext{
${ }^{9}$ ORGANIZAÇÃO DAS NAÇÕES UNIDAS. Informe sobre la visita al Brasil del Subcomité para la Prevención de La Tortura y Otros Tratos o Penas Crueles, Inhumanos o Degradantes. Geneva, Suiça, 2012, p. 15. Disponível em: http://acnudh.org/wp-content/uploads/2012/09/OPCAT-Brasil1.pdf. Acesso em: 16 set. 2016.

${ }^{10}$ ORGANIZAÇÃO DAS NAÇÕES UNIDAS. Informe sobre la visita al Brasil del Subcomité para la Prevención de La Tortura y Otros Tratos o Penas Crueles, Inhumanos o Degradantes. Geneva, Suiça, 2012, p. 21. Disponível em: http://acnudh.org/wp-content/uploads/2012/09/OPCAT-Brasil1.pdf. Acesso em: 16 set. 2016.

${ }^{11}$ ORGANIZAÇÃO DAS NAÇÕES UNIDAS. Informe sobre la visita al Brasil del Subcomité para la Prevención de La Tortura y Otros Tratos o Penas Crueles, Inhumanos o Degradantes. Geneva, Suiça, 2012, p. 16-20. Disponível em: http://acnudh.org/wp-content/uploads/2012/09/OPCAT-Brasill.pdf. Acesso em: 16 set. 2016.
} 
se um sem número de iniciativas no sentido contrário, como com a edição da Lei $n$. 8.072/90 (Lei de Crimes Hediondos) - que prevê normas processuais e penais mais severas para os crimes arrolados como hediondos -, ou mesmo uma atividade mais intensa no sentido de se criar novos tipos penais ou expandir os já existentes.

De fato, com relação à conduta do Poder Legislativo face ao problema do encarceramento em massa, em pesquisa desenvolvida pela Escola de Direito da Fundação Getúlio Vargas (FGV), verificou-se que quase todos os projetos de lei concernentes à matéria penal apresentados entre os anos de 1984 e 2006, visavam à expansão ou criação de tipos penais (em contraposição à descriminalização de condutas ou restrição de seu alcance) ou ao aumento de penas. No universo de 100 projetos de leis estudados, constataram que, de 579 normas de comportamento, 531 correspondiam à criação de norma de comportamento e 41 à modificação de norma de comportamento (39 diziam respeito à expansão e apenas 02 à redução). De 891 normas de sanção, 837 se referiam à criação e 54 à modificação (das quais 47 correspondiam ao aumento da penalização e 07 à diminuição) $)^{12}$. Isso demonstra a incongruência das iniciativas legislativas face ao contexto de encarceramento em massa e aos investimentos do Poder Executivo no sistema prisional.

No entanto, o foco do presente trabalho é o Poder Judiciário e como ele lida com o quadro de encarceramento em massa, com base nas decisões judiciais resultantes dos conflitos levados a ele. Essa opção foi realizada com base no pressuposto de que a atual situação carcerária é de responsabilidade do Estado, compreendido em seus três Poderes, havendo intensa fiscalização e debate quanto aos Poderes Executivo e Legislativo, com menor incidência quanto ao Poder Judiciário.

Para tanto, propôs-se uma pesquisa de análise jurisprudencial, especificamente sobre a função ressocializadora da pena no âmbito da execução penal, uma vez que a tentativa de efetivação desta função implica invariavelmente considerar a realidade prisional, o posicionamento do recluso nas suas relações com o Estado, a responsabilidade do Estado com relação ao seu discurso oficial e a sua atividade nos casos concretos.

No momento de edição de uma lei, de imposição de sanções de caráter penal a determinados comportamentos, ou mesmo no momento de aplicação prática da pena no processo de conhecimento, a função ressocializadora pode ser evocada de forma

\footnotetext{
${ }^{12}$ Cf. MACHADO, M. et al. Atividade legislativa e obstáculos à inovação em matéria penal no Brasil. Série Pensando o Direito, n. 32, 2010. Disponível em: http://portal.mj.gov.br. Acesso em: 25 maio 2015.
} 
meramente teórica. No entanto, na execução penal, a sua eficácia deve ser aferida no caso concreto, sendo também consideradas as suas deficiências.

Em outras palavras:

Podem ser distinguidos dois conceitos de pena: a pena ficta, isto é, um valor numérico que representa, primariamente, a criminalização abstrata decorrente da avaliação discricionária do Poder Legislativo e, secundariamente, a medida de individualização da conduta realizada; e a pena real, qual seja, uma assimilação realista das (precárias) condições locais de cumprimento da privação de liberdade. ${ }^{13}$

A Lei de Execução Penal (Lei n. 7.210, de 11 de julho de 1984 - LEP), então, estabelece como seu princípio norteador a finalidade de reintegração social e oferece os instrumentos para a sua realização, cabendo ao Poder Executivo implementar nas unidades prisionais as condições materiais para a sua efetivação, e ao Poder Judiciário a concretização dos dispositivos legais. ${ }^{14}$

As cortes, por meio de suas decisões, têm papel relevante na definição de políticas criminais e na sua efetividade. O Poder Judiciário, como intérprete e aplicador da lei, possui o poder de tornar inócua qualquer iniciativa do Poder Legislativo ou Executivo, se não aplicar a orientação por trás daquela iniciativa e efetivá-la em seu processo decisório.

Em decorrência da sua atividade no caso concreto, lidando com indivíduos concretos, o Poder Judiciário pode (e deve) verificar a efetivação dos ideais do Estado e, no caso específico do presente trabalho, os objetivos de reintegração social do sentenciado, devendo, para tanto, considerar os dados empíricos acerca do cumprimento de pena no

\footnotetext{
${ }^{13}$ TAVARES, Juarez. Parecer acerca da relação entre as condições concretas de funcionamento do sistema prisional e o alcance dos objetivos manifestos da pena, bem como sobre a viabilidade de o Poder Judiciário levar em conta tais condições nos momentos da fixação e execução das penas privativas de liberdade e medidas cautelares de prisão. Brasília, 07 abr. 2015. Disponível em: http://emporiododireito.com.br/juareztavares-diz-que-nao-se-pode-prender-no-brasil-falta-responsabilidade-do-estado-e-de-seus-magistrados/. Acesso em: 16 set. 2016.

${ }^{14}$ SCAPINI, inclusive, chama a atenção para o disposto no artigo 66, VI, VII e VIII, da Lei de Execução Penal (Art. 66. Compete ao Juiz da execução: [...] VI - zelar pelo correto cumprimento da pena e da medida de segurança; VII - inspecionar, mensalmente, os estabelecimentos penais, tomando providências para o adequado funcionamento e promovendo, quando for o caso, a apuração de responsabilidade; VIII - interditar, no todo ou em parte, estabelecimento penal que estiver funcionando em condições inadequadas ou com infringência aos dispositivos desta Lei;), que atribui ao magistrado o poder de efetivar as previsões da LEP e combater as violações perpetradas pelo sistema carcerário, sem que seja necessária sua provocação, ou seja, podendo atuar de ofício. In: SCAPINI, Marco Antonio Bandeira. Execução Penal: Controle da Legalidade. In: CARVALHO, Salo de (coord.). Crítica à Execução Penal. 2. ed. rev. ampl. e atual. Rio de Janeiro: Lumen Juris, 2007, p. 310.
} 
Brasil. É sua função garantir os direitos dos sentenciados e fiscalizar o andamento da finalidade de ressocialização, sendo esta compreendida como o fornecimento das condições materiais para a reintegração social daqueles privados de liberdade. Há, portanto, a latente necessidade de, compreendendo o papel desempenhado pelo Poder Judiciário no contexto democrático, verificar o processo de tomada de decisão dos tribunais e os efeitos práticos e políticos da atuação das cortes.

O presente trabalho, então, é dividido em quatro capítulos, sendo dois teóricos, um metodológico e um dedicado à análise dos acórdãos selecionados e que compõe o ponto central da pesquisa.

No primeiro capítulo, teórico, o foco será demonstrar como a função ressocializadora é um conceito polissêmico e em disputa no campo jurídico, que serviu para compor diversos discursos diferentes ao longo de sua história. Dessa forma, serão apontadas as críticas dirigidas a essa finalidade e à experiência carcerária, a partir de trabalhos teóricos e constatações práticas, como os estudos de GOFFMAN e MARTINSON. Além disso, serão retomadas diversas ideias que a utilizaram como fundamento para a humanização das penas e para as reformas penitenciárias, desde os correcionalistas espanhóis até formulações mais recentes, como os trabalhos de RODRIGUES e ROXIN, passando pelas ideias dos defensores da Nova Defesa Social. Em seguida, buscar-se-á identificar as feições que essa finalidade deve assumir na atualidade, de acordo com os avanços teóricos e, principalmente, à luz da Constituição Federal de 1988.

Ainda no primeiro capítulo, será feita uma exposição teórica dos institutos da progressão de regime e do livramento condicional, uma vez que são dois instrumentos previstos para se atingir a ressocialização e foram utilizados para a presente pesquisa.

No segundo capítulo, também teórico, será feita uma análise acerca da função do Poder Judiciário, mostrando a sua importância como produtor de direito, mas também delimitando a sua responsabilidade em um Estado dirigente, como é o caso do Brasil após a promulgação da Constituição Federal de 1988, com suas finalidades sociais e o amplo espectro de direitos fundamentais que visa a efetivar. Com esse capítulo, ainda, buscar-se-á delimitar como deveria ser a atuação do Poder Judiciário na execução penal, tendo em vista a função ressocializadora da pena. 
Em seguida, será elaborado um capítulo metodológico, expondo as diversas opções que foram realizadas ao longo da presente pesquisa, acerca dos recortes temporais, espaciais e de tema. Cada uma dessas opções e os seus fundamentos serão explicitados nesse capítulo, bem como será feita uma breve exposição dos acórdãos encontrados, recorrendo-se aos aspectos quantitativos das decisões, embora não seja o objeto principal do trabalho. Também com o intuito de situar o leitor na pesquisa, será feita breve descrição sobre os principais argumentos utilizados por recorrentes e recorridos nos acórdãos selecionados, por serem estes os atores processuais que também disputam o dizer o direito que culmina nas decisões judiciais.

Por fim, no quarto e último capítulo da dissertação, far-se-á o exame das linhas argumentativas encontradas nos acórdãos. Como são muitas as informações disponíveis, optou-se por selecionar os principais argumentos utilizados, bem como as categorias mais recorrentes nos acórdãos, de forma a permitir explicitar como se deram os processos de tomada de decisão, as opções políticas feitas pelos magistrados e a ideologia que permeia a execução penal brasileira, que passa pelo uso da progressão de regime e do livramento condicional, a forma como o magistrado enxerga o sentenciado e a si mesmo, na sua atividade jurisdicional, e, principalmente, para permitir analisar como a função ressocializadora tem sido utilizada e quais conteúdos ela justifica.

Assim, primeiramente serão traçados os principais argumentos com relação à função ressocializadora da pena de uma forma mais ampla, para depois passar à análise de categorias mais específicas, como a utilização do exame criminológico, a personalidade do agente, a periculosidade, a gravidade do delito e a pena a cumprir e, por fim, o princípio do in dubio pro societate. Serão analisados, ainda, os argumentos relacionados à atividade jurisdicional, pelos princípios do livre convencimento e da individualização da pena, e também no sentido de como o magistrado enxerga o seu papel como juiz. 


\section{CONCLUSÕES}

A função ressocializadora, assim, deve ser interpretada de acordo com a sua construção histórica, ao fundamentar movimentos de reforma penitenciária e de humanização da prisão, bem como deve ser interpretada à luz da Constituição Federal, além dos avanços das doutrinas e das elaborações teóricas, e os compromissos internacionais assumidos pelo Brasil, como no Pacto de São José da Costa Rica. Com essa abordagem, verifica-se que não poderia ser utilizada para a ingerência estatal na individualidade e intimidade do sentenciado, mas como compromisso com a implementação de condições materiais para que a reintegração social seja possível, ou ao menos a não dessocialização completa dos apenados. Somente por meio do fornecimento de condições dignas de cumprimento de pena poderia se cogitar a legitimidade da aplicação da penalidade da privação de liberdade por um Estado Democrático de Direito.

Nos acórdãos analisados, no entanto, o que se notou foi que é outra a ideia de função ressocializadora que prevalece nas decisões dos magistrados, ou seja, é outra a noção de ressocialização que tem efetiva aplicação nas vidas dos encarcerados.

Primeiramente, deve-se apontar que raramente houve preocupação com o fornecimento de condições materiais para a reintegração social na execução penal. Os magistrados que mais deferiram benefícios adotaram o princípio da legalidade e a realidade do sistema prisional foi utilizada como reforço para privilegiarem a liberdade dos sentenciados, na tentativa de não deixarem estes por mais tempo submetidos ao seu ambiente criminógeno. Em alguns casos, foram mantidos benefícios "prematuramente" deferidos em primeira instância, com base no comportamento carcerário do sentenciado no novo regime ou no livramento condicional.

Tais decisões se limitam ao quanto previsto em lei, não exercendo nem mais e nem menos o poder punitivo do qual possuem monopólio. A responsabilidade do magistrado, nesses casos, é assumida por meio da garantia dos direitos individuais dos apenados, não permitindo a permanência do indivíduo por mais tempo no cárcere do que seria autorizado em lei. Pode-se concluir, por um raciocínio meramente matemático, que a soltura dos sentenciados que possuem esse direito auxilia o combate ao encarceramento em massa, uma vez que ao menos se está abrindo mais espaço para os demais sentenciados naqueles estabelecimentos penais. 
No entanto, o que prevaleceu foi a adoção de critérios extralegais, como a personalidade do agente, a periculosidade, a gravidade do delito e a pena a cumprir, a reincidência, entre outros. Sem uma interferência do Poder Judiciário no sentido de verificar quais eram as condições carcerárias ou o que era oferecido para a ressocialização, os sentenciados foram mantidos presos com fundamento nessa finalidade, constatando-se uma concepção de ressocialização que mais se aproxima da escola criminológica do positivismo italiano, com elaborações sobre as subjetividades dos sentenciados. Nesses casos, a ressocialização se torna mais um instrumento de repressão, não havendo sequer a assunção de responsabilidade pelos direitos individuais do preso, sendo mais comum a assunção de responsabilidade com relação à sociedade e à coletividade, como se o juiz fosse um garantidor da segurança pública.

Não são levadas em consideração as condições reais de cumprimento de pena e a sua dimensão aflitiva ou, quando são, é para justificar a realização do exame criminológico ou para denegar benefícios, com base no discurso sobre a prisionização.

A partir do momento em que o compromisso do magistrado é com a coletividade, predomina a função de neutralização do indivíduo encarcerado, mesmo que o discurso seja com relação à função ressocializadora. Quando isso ocorre, não há maiores preocupações com o fato de que as prisões brasileiras se tornaram mais um depósito de pessoas indesejadas, que não apenas estão sujeitas à sua privação de liberdade, mas tem outros direitos violados, como a integridade física, moral e psíquica, a sua saúde, e até mesmo a vida.

Mesmo quando os acórdãos não são nesse sentido, verificou-se que a execução penal é uma área na qual os limites do poder punitivo não são exercidos, como se fosse impermeável aos avanços teóricos e doutrinários e aos princípios constitucionais como a legalidade, culpabilidade, humanidade, lesividade, subsidiariedade etc.

Com efeito, os diversos critérios extralegais podem ser utilizados em conjunto, separadamente ou em diversas combinações, a depender dos dados que são levados para os autos e dos julgamentos morais que o magistrado faz do sentenciado. Eles servem para deferir ou denegar benefícios ou, ainda, determinar a realização do exame criminológico. Uma vez que este é realizado, novamente trazendo para a execução conceitos e julgamentos subjetivos, pode ser favorável, desfavorável ou com pareceres conflitantes. $\mathrm{O}$ magistrado, então, pode se vincular ao resultado, escolher trechos, afastar o exame criminológico ou, ainda, determinar a realização de perícia psiquiátrica. E, novamente, 
poderá utilizar quaisquer dos critérios já elencados ou escolher os elementos do exame criminológico, tudo em prol da individualização da pena e apoiado em seu livre convencimento.

As provas são livres, os julgamentos são livres e os princípios e garantias processuais não são levados em consideração. Não há o mínimo de segurança jurídica quanto ao resultado das decisões dos magistrados e a execução penal se torna uma seara na qual o espaço de discricionariedade é tamanho que acaba configurando arbitrariedade judicial.

De fato, não há como o sentenciado conhecer os julgamentos que serão feitos a seu respeito ou quais as condutas que deve ter para ver concedido o seu benefício, dependendo menos do seu comportamento e mais dos peritos que realizarão seu exame e, principalmente, do magistrado que decidirá o seu caso.

Esse amplo espaço para o exercício das subjetividades do magistrado, sua concepções sobre o sentenciado, sobre o crime cometido, sobre o que deve ser a execução penal e como deve ser aplicada a função ressocializadora da pena, ainda, acaba implicando a prevalência das penas indeterminadas na execução penal. Com efeito, a pena não é apenas a quantidade de anos, meses ou dias de privação de liberdade impostos, mas também a forma com que é cumprida, podendo ser mais ou menos pena, a depender do estabelecimento prisional e do regime fixado.

A imprevisibilidade que cerca a concessão de benefícios faz com que seja desconhecida exatamente qual a dimensão da pena que está sendo cumprida, violando princípios constitucionais como o da legalidade, da individualização da pena, da pena certa ou a vedação a penas cruéis.

Ademais, não se sabe exatamente qual o efeito de tais incertezas e arbitrariedades para o sentenciado, mas não seria exagerado afirmar que viola a sua integridade psíquica, prejudicando seu engajamento em qualquer processo ressocializador (no sentido de orientar a sua conduta para as regras impostas) ou mesmo a credibilidade do Poder Judiciário.

A presente pesquisa demonstrou a incerteza que predomina na execução penal e o atraso das doutrinas que permeiam o cumprimento de pena e a atividade jurisdicional, com a utilização de conceitos ultrapassados e que acabam por privilegiar a expansão do poder punitivo, tendo em vista os critérios objetivos previstos na Lei de Execução Penal. 
Fica evidente, por meio dos resultados expostos, que o Poder Judiciário não apenas não se responsabiliza pela efetivação da função ressocializadora da pena, mas também tende a não decidir de acordo com a realidade prisional brasileira, sendo conivente e fomentador do encarceramento em massa.

Com efeito, os discursos legitimadores da prisão no Brasil e da manutenção do sentenciado no cárcere por mais tempo do que aquele permitido por lei, além da utilização de mecanismos que não funcionam quando comparados com a realidade carcerária brasileira, tais como exame criminológico para a individualização da pena e crença na "terapêutica prisional", demonstram que os magistrados que seguem essa linha de entendimento não apenas ignoram a realidade prisional como utilizam tais discursos de maneira meramente formal, sem de fato se preocuparem com a sua concretização. Contribuem, assim, para o agravamento da situação carcerária, com a sua superlotação e a escassez de recursos para atender a toda a população prisional. 


\section{BIBLIOGRAFIA}

ANCEL, Marc. A Nova Defesa Social: Um Movimento de Política Criminal Humanista. Tradução de Osvaldo Melo. 2. ed. Rio de Janeiro, Forense, 1971.

ANDRADE, Vera Regina Pereira de. Minimalismos, abolucionismos e eficienticismo: a crise do sistema penal entre a deslegitimação e a expansão. Revista Sequência, n. 52, p. 163-182, jul. 2006.

ANDREUCCI, Ricardo Nunes. Direito Penal e Criação Judicial. São Paulo: Revista dos Tribunais, 1989.

ANITUA, Gabriel Ignacio. Histórias dos pensamentos criminológicos. Tradução de Sérgio Lamarão. Rio de Janeiro: Revan: Instituto Carioca de Criminologia, 2008.

ANTÓN ONECA, José. La Utopia Penal de Dorado Montero. In: Obras Tomo II. Santa Fe/Argentina: Rubinzal Culzoni Editores, 2002, p. 99-191.

ANTÓN ONECA, José. Obras Tomo III. Santa Fe/Argentina: Rubinzal Culzoni Editores, 2003.

ARAÚJO JR., João Marcello de. Os grandes movimentos da política criminal de nosso tempo: aspectos. In: (Org.). Sistema penal para o terceiro milênio: atos do colóquio Marc Ancel. Rio de Janeiro: Revan, 1991, p. 65-79.

ARAÚJO, Maria Juliana Moraes de. A Execução Penal como Extensão da Atividade Jurisdicional. In: ARAÚJO JR., João Marcello de (coord.). Privatização das Prisões. São Paulo: Revista dos Tribunais, 1995, p. 49-60.

ARENAL, Concepción. Estudios penitenciarios. v. 1. Madri, Espanha: Librería de Victoriano Suarez, 1895.

ARENAL, Concepción. Estudios penitenciarios. v. 2. Madri, Espanha: Librería de Victoriano Suarez, 1895.

ASSOCIAÇÃO INTERNACIONAL DE DEFESA SOCIAL E POLÍTICA CRIMINAL HUMANA. By-Laws of the International Society of Social Defence and Humane Criminal Policy - ISSD. Milão, Itália, 1954. Disponível em: http://www.defensesociale.org/ingles/estatutos_i.pdf. Acesso em: 11 fev. 2016. 
BACILA, Carlos Roberto. Estigmas: um estudo sobre os preconceitos. Rio de Janeiro: Lumen Juris, 2005.

BARATTA, Alessandro. Criminologia crítica e crítica do direito penal. Tradução de Juarez Cirino dos Santos. 6. ed. Rio de Janeiro: Revan/ICC, 2011.

BARATTA, Alessandro. Resocialización o control social: por un concepto crítico de "reintegración social" del condenado. In: ARAÚJO JR., João Marcello de. (Org.). Sistema penal para o terceiro milênio: atos do colóquio Marc Ancel. Rio de Janeiro: Revan, 1991, p. 251-265.

BARROS, Carmen Silvia de Moraes. As modificações introduzidas nos arts. $6^{\circ}$ e 112 da LEP pela Lei 10.792/2003. Revista Brasileira de Ciências Criminais, São Paulo, v. 12, n. 48, p. 179-193, mai./jun. 2004.

BATISTA, Vera Malaguti de Souza Weglinski. O proclamado e o escondido: a violência da neutralidade técnica. Discursos Sediciosos: crime, direito e sociedade, Rio de Janeiro, v. 2, n. 3, p. 77-86, 1997.

BECCARIA, Cesare. Dos Delitos e Das Penas. Tradução de Paulo M. Oliveira. 2. ed. 2 tiragem. Bauru: EDIPRO, 2011.

BITENCOURT, Cezar Roberto. Falência da pena de prisão: causas e alternativas. 2. ed. São Paulo: Saraiva, 2001.

BITENCOURT, Cezar Roberto. Tratado de Direito Penal. 16. ed. São Paulo: Saraiva, 2011.

BITTENCOURT, Ila Barbosa. A instituição do livramento condicional. In: SILVA, Marco Antonio Marques da. Processo penal e garantias constitucionais. São Paulo: Quartier Latin, 2006, p. 317-340.

BOOTH, Wayne C.; COLOMB, Gregory G.; WILLIAMS, Joseph M. A arte da pesquisa. Tradução Henrique A. Rego Monteiro. 2. ed. São Paulo: Martins Fontes, 2005.

BOSCHI, Jose Antonio Paganella. Individualização da Pena. In: CARVALHO, Salo de (coord.) Crítica à Execução Penal. 2. ed. rev. ampl. e atual. Rio de Janeiro: Lumen Juris, 2007, p. 119-138. 
BOURDIEU, Pierre. O poder simbólico. Tradução de Fernando Tomaz. 16. ed. Rio de Janeiro: Bertrand Brasil, 2012.

BOURDIEU, Pierre. Poder, Derecho y Clases Sociales. 2. ed. Tradutores diversos. Bilbao, Espanha: Desclée de Brouwer, 2001.

BRAGA, Ana Gabriela Mendes. A identidade do preso e as leis do cárcere. 2008. $205 f$. Dissertação (Mestrado em Criminologia). Faculdade de Direito, Universidade de São Paulo, São Paulo. 2008.

BRASIL. Constituição (1988). Constituição da República Federativa do Brasil. Brasília, DF: $\quad$ Senado, $1988 . \quad$ Disponível em: http://www.planalto.gov.br/ccivil_03/constituicao/constituicaocompilado.htm.

BRASIL. Decreto-Lei n. 2.848, de 07 de dezembro de 1940. Código Penal. Diário Oficial da União, Brasília, DF, 31 dez. 1940. Seção 1. Disponível em: http://www.planalto.gov.br/ccivil_03/decreto-lei/del2848compilado.htm.

BRASIL. Lei n. 10.792, de $1^{\circ}$ de dezembro de 2003. Altera a Lei n. 7.210, de 11 de junho de 1984 - Lei de Execução Penal e o Decreto-Lei n. 3.689, de 3 de outubro de 1941 Código de Processo Penal e dá outras providências. Diário Oficial da União, Brasília, DF, 2 dez. 2003. Seção 1.2 Disponível em: https://www.planalto.gov.br/ccivil_03/leis/2003/L10.792.htm.

BRASIL. Lei n. 7.210, de 11 de julho de 1984. Institui a Lei de Execução Penal. Diário Oficial da União, Brasília, DF, 13 jul. 1984. Seção 1. Disponível em: http://www.planalto.gov.br/ccivil_03/leis/L7210compilado.htm.

BRASIL. Mensagem n. 242, de 29 de junho de 1983 (Do Poder Executivo). Submete à deliberação do Congresso Nacional o Projeto de Lei de Execução Penal, acompanhado da Exposição de Motivos. Diário do Congresso Nacional, Poder Legislativo, Brasília, DF, 09 mar. 1984. Seção I, p. 84-97. Disponível em: http://imagem.camara.gov.br/Imagem/d/pdf/DCD09MAR1984.pdf\#page=34. Acesso em: 02 jul. 2015.

BRASIL. Supremo Tribunal Federal. Habeas Corpus n. 106.678, do Tribunal de Justiça do Estado do Espírito Santo, Brasília, DF, 28 de fevereiro de 2012. Disponível em: www.stf.jus.br. Acesso em: 10 abr. 2015. 
BRUM, Nilo Bairros de. Requisitos retóricos da sentença penal. São Paulo: Revista dos Tribunais, 1980.

CAMARGO, Antônio Luís Chaves. Direitos humanos e direito penal: limites da intervenção estatal no estado democrático de direito. In: SHECAIRA, Sérgio Salomão (org.). Estudos criminais em homenagem a Evandro Lins e Silva: criminalista do século. São Paulo: Método, 2001, p. 73-80.

CAMARGO, Antônio Luís Chaves. Tipo penal e linguagem. Rio de Janeiro: Forense, 1982.

CAMPILONGO, Celso Fernandes. O Judiciário e a democracia no Brasil. Revista USP, São Paulo, n. 21, p. 116-125, 1994. Disponível em: http://www.revistas.usp.br/revusp/article/view/26940. Acesso em: 25 mar. 2016.

CAPPELlETTI, Mauro. Juízes legisladores? Tradução de Carlos Alberto Alvaro de Oliveira. Porto Alegre: Sergio Antonio Fabris, 1999.

CAPPELlETTI, Mauro. Processo, ideologias e sociedade. Tradução de Elício de Cresci Sobrinho. Porto Alegre: Sergio Antonio Fabris, 2008.

CARLOMAGNO, Márcio Cunha. Constituindo realidades: sobre A força do direito de Pierre Bourdieu. Sociologia, Revista da Faculdade de Letras da Universidade do Porto, v. 22, p. 245-249, 2011.

CARVALHO, Salo de. Antimanual de Criminologia. Rio de Janeiro: Lumen Juris, 2008.

CARVALHO, Salo de. Como não se faz um trabalho de conclusão. 2. ed. 2. tiragem. São Paulo: Saraiva, 2013.

CARVALHO, Salo de. Da Necessidade de Efetivação do Sistema Acusatório no Processo de Execução Penal. In: CARVALHO, Salo de (coord.). Crítica à Execução Penal. 2. ed. rev. ampl. e atual. Rio de Janeiro: Lumen Juris, 2007, p. 417-427.

CARVALHO, Salo de. Memória e esquecimento nas práticas punitivas. In: Criminologia e sistemas jurídicos-penais contemporâneos. Porto Alegre: EDI-PUCRS, 2008, p. 57-92.

CARVAlHO, Salo de. O (Novo) Papel dos "Criminólogos" na Execução Penal: As Alterações Estabelecidas pela Lei 10.792/03. In: CARVALHO, Salo de (coord.). Crítica à 
Execução Penal. 2a ed. rev. ampl. e atual. Rio de Janeiro: Lumen Juris, 2007, p. 159-173.

CARVALHO, Salo de. Penas e Garantias. 2. ed. rev. e atual. Rio de Janeiro: Lumen Juris, 2003.

CARVALHO, Salo de. Penas e medidas de segurança no direito penal brasileiro. 2. ed. São Paulo: Saraiva, 2015.

CARVAlHO, Salo de. Teoria Agnóstica da Pena: Entre os Supérfluos Fins e a Limitação do Poder Punitivo. In: Crítica à Execução Penal. 2a ed. rev., ampl. e atual. Rio de Janeiro: Lumen Juris, 2007, p. 3-28.

CHIES, Luiz Antônio Bogo. Prisão: Tempo, Trabalho e Remição. Reflexões Motivadas pela Inconstitucionalidade do Artigo 127 da LEP e outros Tópicos Revisitados. In: CARVALHO, Salo de (coord.). Crítica à Execução Penal. 2a ed. rev. ampl. e atual. Rio de Janeiro: Lumen Juris, 2007, p. 529-562.

CINTRA JR., Dyrceu A. Dias. Execução penal e dignidade humana. Revista do Advogado, São Paulo, v. 22, n. 67, p. 65-70, ago. 2002.

CONSELHO FEDERAL DE PSICOLOGIA. Resolução CPF n. 09, de 29 de junho de 2010. Regulamenta a atuação do psicólogo no sistema prisional. Brasília, DF, 2010. Disponível em: http://site.cfp.org.br/wp-content/uploads/2010/07/resolucao2010_009.pdf. Acesso em: 10 out. 2016.

CORCIOLI FILHO, Roberto Luiz. A Corrupção do Judiciário. Revista de Estudos Jurídicos UNESP, v. 17, n. 25, p. 433-474, 2013. Disponível em: http://seer.franca.unesp.br/index.php/estudosjuridicosunesp/article/view/719. Acesso em: 10 mai. 2015.

CORRÊA JR., Alceu; SHECAIRA, Sérgio Salomão; Teoria da pena: finalidades, direito positivo, jurisprudência e outros estudos de ciência criminal. São Paulo: Revista dos Tribunais, 2002.

DALFOVO, Michael Samir; LANA, Rogério Adilson; SILVEIRA, Amélia. Métodos quantitativos e qualitativos: um resgate teórico. Revista Interdisciplinar Científica Aplicada, Blumenau, v. 2, n. 4, p. 01-13, Sem II. 2008.

DALLARI, Dalmo de Abreu. O poder dos juízes. São Paulo: Saraiva, 1996. 
DALLARI, Dalmo de Abreu. O poder político dos juízes. Justiça e Democracia. n. 1, p. 93-100, 1996.

DEPARTAMENTO PENITENCIÁRIO NACIONAL - MINISTÉRIO DA JUSTIÇA. Levantamento Nacional de Informações Penitenciárias - Infopen - Junho de 2014. Brasília, DF, 2014. Disponível em: http://www.justica.gov.br/noticias/mj-divulgara-novorelatorio-do-infopen-nesta-terca-feira/relatorio-depen-versao-web.pdf. Acesso em: 02 out. 2016.

DONADONE, Julio César; GRÜN, Roberto. Participar é preciso! Mas de que maneira? Revista Brasileira de Ciências Sociais, São Paulo, v. 16, n. 47, p. 111-125, out. 2001. Disponível em http://www.scielo.br/pdf/rbcsoc/v16n47/7723.pdf. Acesso em: 02 jul. 2015.

DOTTI, René Ariel. Bases e alternativas para o sistema de penas. 2. ed. São Paulo: Revista dos Tribunais, 1998.

DOTTI, René Ariel. Curso de Direito Penal: Parte Geral. 4. ed. rev. atual. e ampl. São Paulo: Revista dos Tribunais, 2012.

DOTTI, Rene Ariel. Jurisprudência Penal e Ciência do Direito Penal. São Paulo: Instituto Brasileiro de Ciências Criminais (IBCCrim), 2005. DVD.

DOTTI, René Ariel. Os limites democráticos do novo sistema de penas. Estudo de contribuição para a X Conferencia Nacional da Ordem dos Advogados do Brasil. Recife/Olinda: Livrarias Ghignone, 1984.

ECO, Umberto. Como se faz uma tese. Tradução de Gilson Cesar Cardoso de Souza. São Paulo: Perspectiva, 2007.

FARIA, Jose Eduardo. Os desafios do Judiciário. Revista USP, São Paulo, n. 21, p. 46-57, 1994. Disponível em: http://www.revistas.usp.br/revusp/article/view/26935. Acesso em: 27 mar. 2016.

FERNANDES, Antônio Scarance. Execução penal: aspectos jurídicos. Revista do Centro de Estudos Judiciários do Conselho de Justiça Federal, Brasília, v. 3, n. 7, p. 68-83, abr. 1999. Disponível em http://daleth.cjf.jus.br/revista/numero7/artigo8.htm. Acesso em: 15 mai. 2015. [n.p.]

FERRAJOLI, Luigi. Direito e razão: Teoria do Garantismo Penal. Tradução de Ana Paula 
Zomer Sica, Fauzi Hassan Choukr, Juarez Tavares e Luiz Flávio Gomes. 3. ed. São Paulo: Revista dos Tribunais, 2010.

FERRAZ JR., Tercio Sampaio. Introdução ao Estudo do Direito: Técnica, Decisão, Dominação. 4. ed. rev. e ampl. São Paulo: Atlas S.A., 2003.

FERRAZ JR., Tércio Sampaio. O Judiciário frente à divisão dos poderes: um princípio em decadência? Revista USP, São Paulo, n. 21, p. 12-21, 1994. Disponível em: http://www.revistas.usp.br/revusp/article/view/26931. Acesso em: 25 mar. 2016.

FOUCAULT, Michel. A ordem do discurso. Tradução de Laura Fraga de Almeida Sampaio. 3. ed. São Paulo: Edições Loyola, 1996.

FOUCAULT, Michel. A verdade e as formas jurídicas. Tradução de Roberto Cabral de Melo Machado e Eduardo Jardim Morais, supervisão final do texto Léa Porto de Abreu Novaes et al. 3. ed. Rio de Janeiro: NAU, 2009.

FOUCAULT, Michel. Microfísica do poder. 28. ed. Organização, introdução e revisão técnica de Roberto Machado. Rio de Janeiro: Paz e Terra, 2014.

FOUCAULT, Michel. Vigiar e Punir: Nascimento da prisão. Tradução de Raquel Ramalhete. Petrópolis: Vozes, 2009.

FRANÇA, Rubens Limongi. Hermenêutica Jurídica. 2. ed. rev e ampl. São Paulo: Saraiva, 1988.

FRANÇA, Rubens Limongi. O direito, a lei a e jurisprudência. São Paulo: Revista dos Tribunais, 1974.

FREITAS FILHO, Roberto. Decisões jurídicas e teoria linguística: O prescritivismo universal de Richard Hare. Revista de Informação Legislativa, Brasília, v. 45, n. 178, p. 1943, abr./jun. 2008.

GARCÍA INDA, Andrés. Introducción: la razón del derecho: entre habitus y campo. In: BOURDIEU, Pierre. Poder, derecho y clases sociales. Tradutores diversos. Bilbao, Espanha: Desclée de Brouwer, 2001, p. 9-57.

GOFFMAN, Erving. Manicômios, prisões e conventos. Tradução de Dante Moreira Leite. São Paulo: Perspectiva, 2013. 
GOMES FILHO, Antônio Magalhães. A motivação das decisões penais. São Paulo: Revista dos Tribunais, 2001.

GOMES, Mariângela Gama de Magalhães. Direito penal e interpretação jurisprudencial: do princípio da legalidade às súmulas vinculantes. São Paulo: Atlas, 2008.

GOMES, Mariângela Gama de Magalhães. O valor normativo da jurisprudência penal. 2007. 231f. Tese (Doutorado em Direito Penal). Faculdade de Direito, Universidade de São Paulo, São Paulo. 2007.

GOMES, Mariângela Gama de Magalhães. Periculosidade no Direito Penal contemporâneo. In: MENDES, Gilmar Ferreira; BOTTINI, Pierpaolo Cruz; PACELLI, Eugênio (coord.). Direito Penal Contemporâneo: Questões Controvertidas. São Paulo: Saraiva, 2011, p. 237-253.

GUINDANI, Miriam Krezinger A. Tratamento Penal: A Dialética do Instituído e do Instituinte. In: CARVALHO, Salo de (coord.) Crítica à Execução Penal. 2. ed. rev. ampl. e atual. Rio de Janeiro: Lumen Juris, 2007, p. 175-188.

GÜNTHER, Klaus. Crítica da pena I (2004). Tradução de Flavia Portella Püschel. Revista Direito GV, v. 2, n. 2, p. 187-203, jul./dez. 2006.

GÜNTHER, Klaus. Crítica da pena II. Tradução de Flavia Portella Püschel. Revista Direito $G V$, v. 3, n. 1, p. 137-149, jan./jun. 2007.

HASSEMER, Winfried. Direito penal: fundamentos, estrutura, política. VASCONCELOS, Carlos Eduardo de Oliveira (org.). Tradução de Adriana Beckman Meirelles, Carlos Eduardo de Oliveira Vasconcelos, Felipe Rhenius Nitzke, Mariana Ribeiro de Souza e Odim Brandão Ferreira. Porto Alegre: Sergio Antonio Fabris, 2008.

HEGEL, Georg Wilíelm Friedrich. Princípios da filosofia do direito. Tradução de Orlando Vitorino. São Paulo: Martins Fontes, 1997.

HOENISCH, Julio Cesar Diniz. A Psicologia entre Nuvens e Granito: Problematizando as Perícias Criminais. In: CARVALHO, Salo de (coord.) Crítica à Execução Penal. 2. ed. rev. ampl. e atual. Rio de Janeiro: Lumen Juris, 2007, p. 189-195.

JUNQUEIRA, Gustavo Octaviano Diniz. Jurisdicionalização da Execução Penal. In: 
BRITO, Alexis Augusto Couto de; VANZOLINI, Maria Patrícia (coord.). Direito Penal: aspectos jurídicos controvertidos. São Paulo: Quartier Latin, 2006, p. 368-384.

KANT, Immanuel. Metafísica dos costumes: primeira parte. Tradução de Célia Aparecida Martins. Petrópolis: Vozes; Bragança Paulista: Universitária São Francisco, 2013.

KARAM, Maria Lúcia. Aplicação da pena: por uma nova atuação da justiça criminal. Revista Brasileira de Ciências Criminais, v. 2, n. 6, p. 117-132, abr./jun. 1994.

KARAM, Maria Lúcia. Disciplina do livramento condicional no ordenamento jurídicopenal brasileiro e violações a direitos fundamentais. In: MARCHI JR., Antônio de Padova; PINTO, Felipe Martins (coord.). Execução Penal: constatações, críticas, alternativas e utopias. Curitiba: Juruá, 2008, p. 149-182.

KARAM, Maria Lúcia. Pelo rompimento com as fantasias em torno de delitos e de penas. Revista Brasileira de Ciências Criminais, v. 8, n. 29, p. 331-350, jan./mar. 2000.

LOPES JR., Aury. Revisitando o Processo de Execução Penal a Partir da Instrumentalidade Garantista. In: CARVALHO, Salo de (coord.) Crítica à Execução Penal. 2. ed. rev. ampl. e atual. Rio de Janeiro: Lumen Juris, 2007, p. 371-406.

LOPES, José Reinaldo de Lima. Hermenêutica e completude do ordenamento. Revista de informação legislativa, Brasília, v. 26, n. 104, p. 237-246, out./dez. 1989. Disponível em: http://www2.senado.leg.br/bdsf/item/id/181976. Acesso em: 13 set. 2015.

MACHADO, M. et al. Atividade legislativa e obstáculos à inovação em matéria penal no Brasil. Série Pensando o Direito, n. 32, 2010. Disponível em: http://portal.mj.gov.br. Acesso em: 25 maio 2015.

MACHONOCHIE, Alexander. Australiana; thoughts on convict management and other subjects connected with the Australian penal colonies. Memphis: General Books LLC, 2012.

MACONOCHIE, Alexander. The principles of punishment: on which the mark system of prison discipline is advocated. London: J. Ollivier, Pall Mall, 1850.

MARRONE, José Marcos. Há jurisdição na execução penal. Justitia, São Paulo, n. 44, p. 82-97, jan./mar. 1982. 
MARTINSON, Robert. What works? Questions and answers about prison reform. The Public Interest, n. 35, p. 22-53, primavera 1974. Disponível em http://www.nationalaffairs.com/public_interest/detail/what-works-questions-and-answersabout-prison-reform. Acesso em: 24 abr. 2015.

MAXIMILIANO, Carlos. Hermenêutica e aplicação do direito. 3. ed. ampl. Rio de Janeiro: Freitas Bastos, 1941.

MELlo, Celso Antônio Bandeira de. Curso de Direito Administrativo. 32. ed. São Paulo: Malheiros, 2015.

MELOSSI, Dario; PAVARINI, Massimo. Cárcere e fábrica: As origens do sistema penitenciário (séculos XVI - XIX). Tradução de Sério Lamarão. 2. ed. Rio de Janeiro: Revan/ICC, 2010. [Pensamento criminológico, v. 11].

NETTO, Alexandre Orsi. A falácia do in dubio pro societate como princípio no processo de execução criminal. Boletim IBCCRIM, São Paulo, v. 17, n. 204, p. 14-15, nov. 2009.

OLIVEIRA, Rômulo Rafael de. Normas constitucionais programáticas. MPMG Jurídico: Revista do Ministério Público do Estado de Minas Gerais, Belo Horizonte, v. 2, n. 10, p. 26-28, jul./ago. 2007.

ORGANIZAÇÃO DAS NAÇÕES UNIDAS. Informe sobre la visita al Brasil del Subcomité para la Prevención de La Tortura y Otros Tratos o Penas Crueles, Inhumanos o Degradantes. Geneva, Suiça, 2012. 31 p. Disponível em: http://acnudh.org/wpcontent/uploads/2012/09/OPCAT-Brasil1.pdf. Acesso em: 16 set. 2016.

ORGANIZAÇÃO DOS ESTADOS AMERICANOS. Convenção Americana de Direitos Humanos ("Pacto de San Jose da Costa Rica"). San Jose, Costa Rica, 1969. Disponível em: https://www.cidh.oas.org/basicos/portugues/c.convencao_americana.htm. Acesso em: 09 out. 2016.

PALMA, J. B. D.; FEFERBAUM, M.; PINHEIRO, V. M. Meu trabalho precisa de jurisprudência? Como posso utilizá-la? In: QUEIROZ, R. M. R. FEFERBAUM, M. (coord.). Metodologia jurídica: um roteiro prático para trabalhos de conclusão de curso. São Paulo: Saraiva, 2012, p. 137-173.

PALMA, J. B. D.; FEFERBAUM; M., PINHEIRO, V. M. Como organizo informações da jurisprudência que leio? In: QUEIROZ, R. M. R. FEFERBAUM, M. (coord.). Metodologia jurídica: um roteiro prático para trabalhos de conclusão de curso. São Paulo: Saraiva, 2012, p. 295-312. 
PAVARINI, Massimo; GIAMBERARDINO, André. Teoria da pena e execução penal: uma introdução crítica. 2. ed. Rio de Janeiro: Lumen Juris, 2012.

PIMENTEL, Manoel Pedro. Sistemas Penitenciários. Revista dos Tribunais, São Paulo, v. 639, p. 265-277, jan. 1989.

PIMENTEL, Silvia; SCHRITZMEYER, Ana Lúcia Pastore; PANDJIARJIAN, Valéria. Estupro: Crime ou "Cortesia"? Abordagem sociojurídica de gênero. Porto Alegre: Sergio Antonio Fabris, 1998.

PIOVESAN, Flávia. Desenvolvimento histórico dos direitos humanos e a Constituição brasileira de 1988. In: AGRA, Walber de Moura (coord.). Retrospectiva dos 20 anos da Constituição Federal. São Paulo: Saraiva, 2009, p. 17-33.

PIRES, Alvaro. Amostragem e pesquisa qualitativa: ensaios teóricos e metodológicos. In: POUPART, Jean et al (orgs.). A pesquisa qualitativa: enfoques epistemológicos e metodológicos. Tradução de Ana Cristina Nasser. Petrópolis: Vozes, 2008, p. 154-211.

PITOMBO, Sérgio Marcos de Moraes. Pronúncia in dubio pro societate. Revista da Escola Paulista da Magistratura, São Paulo, v. 1, n. 1, p. 9-23, jan./jun. 2003.

PRADO, Geraldo. A Execução Penal e o Sistema Acusatório. In: CARVALHO, Salo de (coord.) Crítica à Execução Penal. 2. ed. rev. ampl. e atual. Rio de Janeiro: Lumen Juris, 2007, p. 407-415.

QUEIROZ, Paulo. Funções do Direito Penal: Legitimação versus Deslegitimação do Direito Penal. 3. ed. São Paulo: Revista dos Tribunais, 2008.

QUEIROZ, R. M. R. Como encontrar um bom tema dentro de minha área de interesse? In: QUEIROZ, R. M. R. FEFERBAUM, M. (coord.). Metodologia jurídica: um roteiro prático para trabalhos de conclusão de curso. São Paulo: Saraiva, 2012, p. 53-79.

REALE JR., Miguel. Aspectos do projeto modificativo da Lei de Execução Penal. In: Revista do Advogado, a. XXIV, n. 78, p. 75-78, set. 2004.

REALE JR., Miguel. Instituições de direito penal: parte geral. 3. ed. Rio de Janeiro: Forense, 2009. 
REALE JR., Miguel. O juiz das garantias. Revista de Estudos Criminais, Porto Alegre, v. 10, n. 43, p. 99-115, out./dez. 2011.

REALE JR., Miguel. Razão e subjetividade no direito penal. Ciências Penais: Revista da Associação Brasileira de Professores de Ciências Penais, São Paulo, v. 1, n. 0, p. 226-249, jan./jun. 2004.

REALE, Miguel. Lições Preliminares de Direito. 24. ed. 3. tiragem. São Paulo: Saraiva, 1999.

RODRIGUES, Anabela Miranda. Novo olhar sobre a questão penitenciária: estatuto jurídico do recluso e socialização, jurisdicionalização, consensualismo e prisão. São Paulo: Revista dos Tribunais, 2001.

RODRIGUEZ, José Rodrigo. Como decidem as cortes? Para uma crítica do direito (brasileiro). Rio de Janeiro: FGV, 2013.

ROIG, Rodrigo Duque Estrada. Execução Penal: teoria crítica. São Paulo: Saraiva, 2014.

ROLIM, Marcos. Prisão e Ideologia: Limites e Possibilidades para a Reforma Prisional no Brasil. In: CARVALHO, Salo de (coord.) Crítica à Execução Penal. 2. ed. rev. ampl. e atual. Rio de Janeiro: Lumen Juris, 2007, p. 77-115.

ROSA, Alexandre Morais da. O papel do Juiz Garantista e a Execução Penal em tempos Neoliberais: Eichmann e Big Brother. In: CARVALHO, Salo de (coord.) Crítica à Execução Penal. 2. ed. rev. ampl. e atual. Rio de Janeiro: Lumen Juris, 2007, p. 319-348.

ROXIN, Claus. Sentidos e Limites da Pena Estatal. In: Problemas Fundamentais de Direito Penal. Tradução de Ana Paula dos Santos Luís Natscheradetz. Lisboa: Coleção Vega Universidade, 1998, p. 13-47.

SÁ, Alvino Augusto de. Criminologia Clínica e Execução Penal: proposta de um modelo de terceira geração. São Paulo: Revista dos Tribunais, 2011.

SÁ, Alvino Augusto de. Criminologia Clínica e Psicologia Criminal, 2. ed. São Paulo: Revista dos Tribunais, 2010.

SÁ, Alvino Augusto de; SHECAIRA, Sérgio Salomão. Criminologia e os Problemas da 
Atualidade. São Paulo: Atlas, 2008.

SALVADOR NETTO, Alamiro Velludo. Finalidades da Pena: conceito material de delito e sistema penal integral. São Paulo: Quartier Latin, 2009.

SÃO PAULO (Estado). Resolução SAP n. 144, de 29 de junho de 2010. Institui o Regimento Interno Padrão das Unidades Prisionais do Estado de São Paulo. Diário Oficial, Poder Executivo, São Paulo, SP, 30 jun. 2010. Seção I, p. 18-21. Disponível em: http://www.sifuspesp.org.br/files/u1/ovo_Regimento_interno_nas_unidades_prisonais.pdf. Acesso em: 08 out. 2016.

SCAPINI, Marco Antonio Bandeira. Execução Penal: Controle da Legalidade. In: CARVALHO, Salo de (coord.). Crítica à Execução Penal. 2. ed. rev. ampl. e atual. Rio de Janeiro: Lumen Juris, 2007, p. 307-318.

SCHMIDT, Andrei Zenkner. A Crise de Legalidade na Execução Penal. In: CARVALHO, Salo de (coord.). Crítica à Execução Penal. 2. ed. rev. ampl. e atual. Rio de Janeiro: Lumen Juris, 2007, p. 29-76.

SCHMIDT, Andrei Zenkner. Direitos, Deveres e Disciplina na Execução Penal. In: CARVALHO, Salo de (coord.). Crítica à Execução Penal. 2. ed. rev. ampl. e atual. Rio de Janeiro: Lumen Juris, 2007, p. 207-267.

SCHROEDER, Simone. Regressão de Regime: Uma Releitura Frente aos Princípios Constitucionais. Abordagem Crítica. In: CARVALHO, Salo de (coord.). Crítica à Execução Penal. 2. ed. rev. ampl. e atual. Rio de Janeiro: Lumen Juris, 2007, p. 473-503.

SHECAIRA, Sérgio Salomão. Criminologia. 4. ed. São Paulo: Revista dos Tribunais, 2012.

SHECAIRA, Sérgio Salomão. Pena e Política Criminal. A experiência Brasileira. In: Criminologia e os Problemas da Atualidade. São Paulo: Atlas, 2008, p. 321-334.

SILVA, Evandro Lins e. De Beccaria a Filippo Gramatica. In: ARAÚJO JUNIOR, João Marcello de (Org.). Sistema penal para o terceiro milênio: atos do colóquio Marc Ancel. Rio de Janeiro: Revan, 1991, p. 17-43.

SILVA, José Afonso da. Aplicabilidade das normas constitucionais programáticas. RPGE, Fortaleza, a. 9, n. 11, p. 43-60, 1992. 
STRECK, Lênio Luiz. A filosofia traída pela dogmática jurídica: uma crítica à noção de verdade e ao livre convencimento no processo penal. In: MALAN, Diogo; MIRZA, Flávio (coord.). Setenta anos do código de processo penal brasileiro: balanço e perspectivas de reforma. Rio de Janeiro: Lumen Juris, 2011, p. 215-248.

STRECK, Lênio Luiz. O livre convencimento e sua incompatibilidade com o dever de accountability hermenêutica: o sistema acusatório e a proteção dos direitos fundamentais no processo penal. In: MALAN, Diogo; PRADO, Geraldo (coord.). Processo penal e direitos humanos. Rio de Janeiro: Lumen Juris, 2014, p. 156-187.

STRECK, Lênio. Nos vinte anos de Constituição, entre verdade e consenso, o dilema contemporâneo: há respostas corretas em direito? In: AGRA, Walber de Moura (coord.). Retrospectiva dos 20 anos da Constituição Federal. São Paulo: Saraiva, 2009, p. 315-340.

TAVARES, Juarez. Parecer acerca da relação entre as condições concretas de funcionamento do sistema prisional e o alcance dos objetivos manifestos da pena, bem como sobre a viabilidade de o Poder Judiciário levar em conta tais condições nos momentos da fixação e execução das penas privativas de liberdade e medidas cautelares de prisão. Brasília, 07 abr. 2015. Disponível em: http://emporiododireito.com.br/juareztavares-diz-que-nao-se-pode-prender-no-brasil-falta-responsabilidade-do-estado-e-de-seusmagistrados/. Acesso em: 16 set. 2016.

THIRTY-CHERQUES, Hermano Roberto. Pierre Bourdieu: a teoria na prática. Revista de Admnistração Pública, Rio de Janeiro, v. 40, n. 1, p. 27-53, fev. 2006. Disponível em: http://www.scielo.br/scielo.php?pid=S0034-76122006000100003\&script=sci_arttext.

Acesso em: 10 abr. 2015.

TORRES, Andrea Almeida. A Lei de Execução Penal e as Atribuições do Serviço Social no Sistema Penitenciário: Conservadorismo pela via da "Dessasistência" Social. In: CARVALHO, Salo de (coord.) Crítica à Execução Penal. 2. ed. rev. ampl. e atual. Rio de Janeiro: Lumen Juris, 2007, p. 197-204.

VALOIS, Luís Carlos. Conflito entre ressocialização e o princípio da legalidade na execução penal. Rio de Janeiro: Lumen Júris, 2013.

VASCONCELLOS, Silvio José L.; KRUG, Jefferson Silva; SILVA, Roberta Salvador. A avaliação psicológica na esfera do Direito Penal: para que serve e a quem serve? In: FAYET JR., Ney; MAYA, André Machado (org.). Ciências penais e sociedade complexa II. Porto Alegre: Nuria Fabris, 2009, p. 393-407.

WACQUANT, Loïc. As prisões da miséria. Tradução de André Telles. Rio de Janeiro: 
Jorge Zahar, 2001.

ZAFFARONI, Eugenio Raul. Dimension política de un poder judicial democratico, Revista Brasileira de Ciências Criminais, São Paulo, v. 1, n. 4, p. 19-46, out./dez. 1993.

ZAFFARONI, Eugenio Raúl. Em busca das penas perdidas: a perda de legitimidade do sistema penal. Tradução de Vânia Romano Pedrosa e Amir Lopes da Conceição. 5. ed. 2. reimpressão. Rio de Janeiro: Revan, 2012.

ZAFFARONI, Eugenio Raúl. O Inimigo no Direito Penal. Tradução de Sérgio Lamarão. 3. ed. Rio de Janeiro: Revan, 2011.

ZAFFARONI, Eugenio Raul; BATISTA, Nilo; ALAGIA, Alejandro; SLOKAR, Alejandro. Direito Penal Brasileiro: primeiro volume - Teoria Geral do Direito Penal. Rio de Janeiro: Revan, 2003.

ZAFFARONI, Eugenio Raúl; PIERANGELI, Jose Henrique. Manual de Direito Penal Brasileiro, v. 1, parte geral, 8. ed. São Paulo: Revista dos Tribunais, 2009.

ZVEIBIL, Daniel Guimarães. O arbítrio palavreado no processo penal: breve ensaio sobre a pronúncia e o in dubio pro societate. Revista Brasileira de Ciências Criminais, São Paulo, v. 16, n. 74, p. 281-298, set./out. 2008. 


\section{APÊNDICE A}

\section{TABELA DE ACÓRDÃOS PESQUISADOS E REFERÊNCIAS}

\begin{tabular}{|c|c|c|c|c|c|}
\hline Ref. & Recurso & $\mathbf{N}^{\circ}$ Processo & $\begin{array}{c}\text { Desembargador } \\
\text { Relator }\end{array}$ & Câmara & $\begin{array}{c}\text { Data do } \\
\text { julgamento }\end{array}$ \\
\hline A1 & $\begin{array}{l}\text { Agravo em } \\
\text { Execução }\end{array}$ & $990.10 .146099-8$ & Péricles Piza & $\begin{array}{c}1^{\mathrm{a}} \\
\text { Câmara } \\
\text { Criminal }\end{array}$ & $16 / 08 / 2010$ \\
\hline $\mathrm{A} 2$ & $\begin{array}{l}\text { Agravo em } \\
\text { Execução }\end{array}$ & $990.10 .341370-9$ & Márcio Bartoli & $\begin{array}{c}1^{\mathrm{a}} \\
\text { Câmara } \\
\text { Criminal }\end{array}$ & $13 / 12 / 2010$ \\
\hline A3 & $\begin{array}{l}\text { Agravo em } \\
\text { Execução }\end{array}$ & $990.10 .345780-3$ & Marco Nahum & $\begin{array}{c}1^{\mathrm{a}} \\
\text { Câmara } \\
\text { Criminal }\end{array}$ & $27 / 09 / 2010$ \\
\hline A4 & $\begin{array}{l}\text { Agravo em } \\
\text { Execução }\end{array}$ & $990.09 .317153-8$ & $\begin{array}{c}\text { Mário Devienne } \\
\text { Ferraz }\end{array}$ & $\begin{array}{c}1^{\mathrm{a}} \\
\text { Câmara } \\
\text { Criminal }\end{array}$ & $22 / 02 / 2010$ \\
\hline A5 & $\begin{array}{l}\text { Agravo em } \\
\text { Execução }\end{array}$ & $990.09 .323686-9$ & Péricles Piza & $\begin{array}{c}1^{\mathrm{a}} \\
\text { Câmara } \\
\text { Criminal }\end{array}$ & $22 / 02 / 2010$ \\
\hline A6 & $\begin{array}{l}\text { Agravo em } \\
\text { Execução }\end{array}$ & $\begin{array}{c}0258314- \\
72.2011 .8 .26 .0000\end{array}$ & Márcio Bartoli & $\begin{array}{c}1^{\mathrm{a}} \\
\text { Câmara } \\
\text { Criminal }\end{array}$ & $19 / 12 / 2011$ \\
\hline A7 & $\begin{array}{l}\text { Agravo em } \\
\text { Execução }\end{array}$ & $\begin{array}{c}0216232- \\
26.2011 .8 .26 .0000\end{array}$ & $\begin{array}{c}\text { Mário Devienne } \\
\text { Ferraz }\end{array}$ & $\begin{array}{c}1^{\mathrm{a}} \\
\text { Câmara } \\
\text { Criminal }\end{array}$ & $05 / 12 / 2011$ \\
\hline A8 & $\begin{array}{l}\text { Agravo em } \\
\text { Execução }\end{array}$ & $\begin{array}{c}\text { 0102529- } \\
20.2011 .8 .26 .0000\end{array}$ & $\begin{array}{l}\text { Figueiredo } \\
\text { Gonçalves }\end{array}$ & $\begin{array}{c}1^{\mathrm{a}} \\
\text { Câmara } \\
\text { Criminal }\end{array}$ & $19 / 09 / 2011$ \\
\hline A9 & $\begin{array}{l}\text { Agravo em } \\
\text { Execução }\end{array}$ & $\begin{array}{c}\text { 0066370- } \\
\text { 78.2011.8.26.0000 }\end{array}$ & Péricles Piza & $\begin{array}{c}1^{\mathrm{a}} \\
\text { Câmara } \\
\text { Criminal }\end{array}$ & 08/08/2011 \\
\hline A10 & Agravo em & 0056279- & Péricles Piza & $1^{\mathrm{a}}$ & $11 / 07 / 2011$ \\
\hline
\end{tabular}




\begin{tabular}{|c|c|c|c|c|c|}
\hline & Execução & 26.2011.8.26.0000 & & $\begin{array}{l}\text { Câmara } \\
\text { Criminal }\end{array}$ & \\
\hline A11 & $\begin{array}{l}\text { Agravo em } \\
\text { Execução }\end{array}$ & $\begin{array}{c}\text { 0206564- } \\
94.2012 .8 .26 .0000\end{array}$ & Márcio Bartoli & $\begin{array}{c}1^{\mathrm{a}} \\
\text { Câmara } \\
\text { Criminal }\end{array}$ & $10 / 12 / 2012$ \\
\hline A12 & $\begin{array}{l}\text { Agravo em } \\
\text { Execução }\end{array}$ & $\begin{array}{c}0191103- \\
82.2012 .8 .26 .0000\end{array}$ & $\begin{array}{c}\text { Mário Devienne } \\
\text { Ferraz }\end{array}$ & $\begin{array}{c}1^{\mathrm{a}} \\
\text { Câmara } \\
\text { Criminal }\end{array}$ & $03 / 12 / 2012$ \\
\hline A13 & $\begin{array}{l}\text { Agravo em } \\
\text { Execução }\end{array}$ & $\begin{array}{c}0116333- \\
21.2012 .8 .26 .0000\end{array}$ & $\begin{array}{l}\text { Figueiredo } \\
\text { Gonçalves }\end{array}$ & $\begin{array}{c}1^{\mathrm{a}} \\
\text { Câmara } \\
\text { Criminal }\end{array}$ & 03/09/2012 \\
\hline A14 & $\begin{array}{l}\text { Agravo em } \\
\text { Execução }\end{array}$ & $\begin{array}{c}\text { 0305710- } \\
\text { 45.2011.8.26.0000 }\end{array}$ & Marco Nahum & $\begin{array}{c}1^{\mathrm{a}} \\
\text { Câmara } \\
\text { Criminal }\end{array}$ & $14 / 05 / 2012$ \\
\hline A15 & $\begin{array}{l}\text { Agravo em } \\
\text { Execução }\end{array}$ & $\begin{array}{c}\text { 0228764- } \\
32.2011 .8 .26 .0000\end{array}$ & Péricles Piza & $\begin{array}{c}1^{\mathrm{a}} \\
\text { Câmara } \\
\text { Criminal }\end{array}$ & $13 / 02 / 2012$ \\
\hline A16 & $\begin{array}{l}\text { Agravo em } \\
\text { Execução }\end{array}$ & $\begin{array}{c}0183537- \\
48.2013 .8 .26 .0000\end{array}$ & Márcio Bartoli & $\begin{array}{c}1^{\mathrm{a}} \\
\text { Câmara } \\
\text { Criminal }\end{array}$ & $16 / 12 / 2013$ \\
\hline A17 & $\begin{array}{l}\text { Agravo em } \\
\text { Execução }\end{array}$ & $\begin{array}{c}0175621- \\
60.2013 .8 .26 .0000\end{array}$ & $\begin{array}{c}\text { Mário Devienne } \\
\text { Ferraz }\end{array}$ & $\begin{array}{c}1^{\mathrm{a}} \\
\text { Câmara } \\
\text { Criminal }\end{array}$ & $25 / 11 / 2013$ \\
\hline A18 & $\begin{array}{l}\text { Agravo em } \\
\text { Execução }\end{array}$ & $\begin{array}{c}7006122- \\
65.2013 .8 .26 .0482\end{array}$ & $\begin{array}{l}\text { Figueiredo } \\
\text { Gonçalves }\end{array}$ & $\begin{array}{c}1^{\mathrm{a}} \\
\text { Câmara } \\
\text { Criminal }\end{array}$ & $04 / 11 / 2013$ \\
\hline A19 & $\begin{array}{l}\text { Agravo em } \\
\text { Execução }\end{array}$ & $\begin{array}{c}\text { 0097606- } \\
77.2013 .8 .26 .0000\end{array}$ & $\begin{array}{l}\text { Figueiredo } \\
\text { Gonçalves }\end{array}$ & $\begin{array}{c}1^{\mathrm{a}} \\
\text { Câmara } \\
\text { Criminal }\end{array}$ & $19 / 08 / 2013$ \\
\hline A20 & $\begin{array}{l}\text { Agravo em } \\
\text { Execução }\end{array}$ & $\begin{array}{c}0124031- \\
44.2013 .8 .26 .0000\end{array}$ & Márcio Bartoli & $\begin{array}{c}1^{\mathrm{a}} \\
\text { Câmara } \\
\text { Criminal }\end{array}$ & $07 / 10 / 2013$ \\
\hline A21 & Agravo em & 0063017- & Ivo de Almeida & $1^{\mathrm{a}}$ & $01 / 12 / 2014$ \\
\hline
\end{tabular}




\begin{tabular}{|c|c|c|c|c|c|}
\hline & Execução & 25.2014 .8 .26 .0000 & & $\begin{array}{l}\text { Câmara } \\
\text { Criminal }\end{array}$ & \\
\hline A22 & $\begin{array}{l}\text { Agravo em } \\
\text { Execução }\end{array}$ & $\begin{array}{c}\text { 0061930- } \\
34.2014 .8 .26 .0000\end{array}$ & Péricles Piza & $\begin{array}{c}1^{\mathrm{a}} \\
\text { Câmara } \\
\text { Criminal }\end{array}$ & $17 / 11 / 2014$ \\
\hline A23 & $\begin{array}{l}\text { Agravo em } \\
\text { Execução }\end{array}$ & $\begin{array}{c}0043014- \\
49.2014 .8 .26 .0000\end{array}$ & Márcio Bartoli & $\begin{array}{c}1^{\mathrm{a}} \\
\text { Câmara } \\
\text { Criminal }\end{array}$ & $10 / 11 / 2014$ \\
\hline A24 & $\begin{array}{l}\text { Agravo em } \\
\text { Execução }\end{array}$ & $\begin{array}{c}\text { 7003517- } \\
\text { 41.2014.8.26.0344 }\end{array}$ & $\begin{array}{l}\text { Figueiredo } \\
\text { Gonçalves }\end{array}$ & $\begin{array}{c}1^{\mathrm{a}} \\
\text { Câmara } \\
\text { Criminal }\end{array}$ & $08 / 09 / 2014$ \\
\hline A 25 & $\begin{array}{l}\text { Agravo em } \\
\text { Execução }\end{array}$ & $\begin{array}{c}0008213- \\
10.2014 .8 .26 .0000\end{array}$ & $\begin{array}{c}\text { Mário Devienne } \\
\text { Ferraz }\end{array}$ & $\begin{array}{c}1^{\mathrm{a}} \\
\text { Câmara } \\
\text { Criminal }\end{array}$ & $26 / 05 / 2014$ \\
\hline A26 & $\begin{array}{l}\text { Agravo em } \\
\text { Execução }\end{array}$ & $990.10 .419863-1$ & $\begin{array}{l}\text { Teodomiro } \\
\text { Mendez }\end{array}$ & $\begin{array}{c}2^{\mathrm{a}} \\
\text { Câmara } \\
\text { Criminal }\end{array}$ & $06 / 12 / 2010$ \\
\hline A27 & $\begin{array}{l}\text { Agravo em } \\
\text { Execução }\end{array}$ & $990.10 .278913-6$ & Paulo Rossi & $\begin{array}{c}2^{\mathrm{a}} \\
\text { Câmara } \\
\text { Criminal }\end{array}$ & $22 / 11 / 2010$ \\
\hline A28 & $\begin{array}{l}\text { Agravo em } \\
\text { Execução }\end{array}$ & $990.09 .270608-0$ & $\begin{array}{c}\text { Francisco } \\
\text { Orlando }\end{array}$ & $\begin{array}{c}2^{\mathrm{a}} \\
\text { Câmara } \\
\text { Criminal }\end{array}$ & $13 / 09 / 2010$ \\
\hline A29 & $\begin{array}{l}\text { Agravo em } \\
\text { Execução }\end{array}$ & $990.10 .039638-2$ & $\begin{array}{l}\text { Antônio Luiz } \\
\text { Pires Neto }\end{array}$ & $\begin{array}{c}2^{\mathrm{a}} \\
\text { Câmara } \\
\text { Criminal }\end{array}$ & $09 / 08 / 2010$ \\
\hline A30 & $\begin{array}{l}\text { Agravo em } \\
\text { Execução }\end{array}$ & $990.10 .146311-3$ & Almeida Sampaio & $\begin{array}{c}2^{\mathrm{a}} \\
\text { Câmara } \\
\text { Criminal }\end{array}$ & $19 / 07 / 2010$ \\
\hline A31 & $\begin{array}{l}\text { Agravo em } \\
\text { Execução }\end{array}$ & $\begin{array}{c}\text { 0172989- } \\
\text { 32.2011.8.26.0000 }\end{array}$ & $\begin{array}{l}\text { Teodomiro } \\
\text { Mendez }\end{array}$ & $\begin{array}{c}2^{\mathrm{a}} \\
\text { Câmara } \\
\text { Criminal }\end{array}$ & $17 / 10 / 2011$ \\
\hline A32 & Agravo em & 0205934- & Paulo Rossi & $2^{a}$ & $19 / 12 / 2011$ \\
\hline
\end{tabular}




\begin{tabular}{|c|c|c|c|c|c|}
\hline & Execução & 72.2011.8.26.0000 & & $\begin{array}{l}\text { Câmara } \\
\text { Criminal }\end{array}$ & \\
\hline A33 & $\begin{array}{l}\text { Agravo em } \\
\text { Execução }\end{array}$ & $\begin{array}{c}0112300- \\
22.2011 .8 .26 .0000\end{array}$ & Silmar Fernandes & $\begin{array}{c}2^{\mathrm{a}} \\
\text { Câmara } \\
\text { Criminal }\end{array}$ & $29 / 11 / 2011$ \\
\hline A34 & $\begin{array}{l}\text { Agravo em } \\
\text { Execução }\end{array}$ & $\begin{array}{c}\text { 0095104- } \\
39.2011 .8 .26 .0000\end{array}$ & $\begin{array}{l}\text { Francisco } \\
\text { Orlando }\end{array}$ & $\begin{array}{c}2^{\mathrm{a}} \\
\text { Câmara } \\
\text { Criminal }\end{array}$ & $17 / 10 / 2011$ \\
\hline A35 & $\begin{array}{l}\text { Agravo em } \\
\text { Execução }\end{array}$ & $\begin{array}{c}0054907- \\
42.2011 .8 .26 .0000\end{array}$ & Almeida Sampaio & $\begin{array}{c}2^{\mathrm{a}} \\
\text { Câmara } \\
\text { Criminal }\end{array}$ & $19 / 09 / 2011$ \\
\hline A36 & $\begin{array}{l}\text { Agravo em } \\
\text { Execução }\end{array}$ & $\begin{array}{c}0187845- \\
64.2012 .8 .26 .0000\end{array}$ & Alex Zilenovski & $\begin{array}{c}2^{\mathrm{a}} \\
\text { Câmara } \\
\text { Criminal }\end{array}$ & $10 / 12 / 2012$ \\
\hline A37 & $\begin{array}{l}\text { Agravo em } \\
\text { Execução }\end{array}$ & $\begin{array}{c}0066898- \\
78.2012 .8 .26 .0000\end{array}$ & $\begin{array}{l}\text { Antonio Luiz } \\
\text { Pires Neto }\end{array}$ & $\begin{array}{c}2^{\mathrm{a}} \\
\text { Câmara } \\
\text { Criminal }\end{array}$ & $12 / 11 / 2012$ \\
\hline A38 & $\begin{array}{l}\text { Habeas } \\
\text { Corpus }\end{array}$ & $\begin{array}{c}0187513- \\
97.2012 .8 .26 .0000\end{array}$ & $\begin{array}{l}\text { Francisco } \\
\text { Orlando }\end{array}$ & $\begin{array}{c}2^{\mathrm{a}} \\
\text { Câmara } \\
\text { Criminal }\end{array}$ & $22 / 10 / 2012$ \\
\hline A39 & $\begin{array}{l}\text { Habeas } \\
\text { Corpus }\end{array}$ & $\begin{array}{c}0107335- \\
64.2012 .8 .26 .0000\end{array}$ & Almeida Sampaio & $\begin{array}{c}2^{\mathrm{a}} \\
\text { Câmara } \\
\text { Criminal }\end{array}$ & $17 / 09 / 2012$ \\
\hline A40 & $\begin{array}{l}\text { Agravo em } \\
\text { Execução }\end{array}$ & $\begin{array}{c}0013702- \\
96.2012 .8 .26 .0000\end{array}$ & Ivo de Almeida & $\begin{array}{c}2^{\mathrm{a}} \\
\text { Câmara } \\
\text { Criminal }\end{array}$ & $11 / 06 / 2012$ \\
\hline A41 & $\begin{array}{l}\text { Habeas } \\
\text { Corpus }\end{array}$ & $\begin{array}{c}\text { 0164309- } \\
87.2013 .8 .26 .0000\end{array}$ & Alex Zilenovski & $\begin{array}{c}2^{\mathrm{a}} \\
\text { Câmara } \\
\text { Criminal }\end{array}$ & $02 / 12 / 2013$ \\
\hline A42 & $\begin{array}{l}\text { Agravo em } \\
\text { Execução }\end{array}$ & $\begin{array}{c}7005452- \\
27.2013 .8 .26 .0482\end{array}$ & $\begin{array}{c}\text { Francisco } \\
\text { Orlando }\end{array}$ & $\begin{array}{c}2^{\mathrm{a}} \\
\text { Câmara } \\
\text { Criminal }\end{array}$ & $11 / 11 / 2013$ \\
\hline A43 & Agravo em & 0124463- & Almeida Sampaio & $2^{a}$ & $07 / 10 / 2013$ \\
\hline
\end{tabular}




\begin{tabular}{|c|c|c|c|c|c|}
\hline & Execução & 63.2013.8.26.0000 & & $\begin{array}{l}\text { Câmara } \\
\text { Criminal }\end{array}$ & \\
\hline A44 & $\begin{array}{l}\text { Agravo em } \\
\text { Execução }\end{array}$ & $\begin{array}{c}0069138- \\
06.2013 .8 .26 .0000\end{array}$ & $\begin{array}{l}\text { Antonio Luiz } \\
\text { Pires Neto }\end{array}$ & $\begin{array}{c}2^{\mathrm{a}} \\
\text { Câmara } \\
\text { Criminal }\end{array}$ & 05/08/2013 \\
\hline A45 & $\begin{array}{l}\text { Agravo em } \\
\text { Execução }\end{array}$ & $\begin{array}{c}0032748- \\
37.2013 .8 .26 .0000\end{array}$ & Alex Zilenovski & $\begin{array}{c}2^{\mathrm{a}} \\
\text { Câmara } \\
\text { Criminal }\end{array}$ & $13 / 05 / 2013$ \\
\hline A46 & $\begin{array}{l}\text { Agravo em } \\
\text { Execução }\end{array}$ & $\begin{array}{c}7006228- \\
19.2014 .8 .26 .0344\end{array}$ & Diniz Fernando & $\begin{array}{c}2^{\mathrm{a}} \\
\text { Câmara } \\
\text { Criminal }\end{array}$ & $15 / 12 / 2014$ \\
\hline A47 & $\begin{array}{l}\text { Agravo em } \\
\text { Execução }\end{array}$ & $\begin{array}{c}0060077- \\
87.2014 .8 .26 .0000\end{array}$ & Alex Zilenovski & $\begin{array}{c}2^{\mathrm{a}} \\
\text { Câmara } \\
\text { Criminal }\end{array}$ & $15 / 12 / 2014$ \\
\hline A 48 & $\begin{array}{l}\text { Agravo em } \\
\text { Execução }\end{array}$ & $\begin{array}{c}0027261- \\
52.2014 .8 .26 .0000\end{array}$ & $\begin{array}{c}\text { Francisco } \\
\text { Orlando }\end{array}$ & $\begin{array}{c}2^{\mathrm{a}} \\
\text { Câmara } \\
\text { Criminal }\end{array}$ & $24 / 11 / 2014$ \\
\hline A49 & $\begin{array}{l}\text { Agravo em } \\
\text { Execução }\end{array}$ & $\begin{array}{c}0023243- \\
85.2014 .8 .26 .0000\end{array}$ & Almeida Sampaio & $\begin{array}{c}2^{\mathrm{a}} \\
\text { Câmara } \\
\text { Criminal }\end{array}$ & $27 / 10 / 2014$ \\
\hline A50 & $\begin{array}{l}\text { Agravo em } \\
\text { Execução }\end{array}$ & $\begin{array}{c}0047473- \\
94.2014 .8 .26 .0000\end{array}$ & Diniz Fernando & $\begin{array}{c}2^{\mathrm{a}} \\
\text { Câmara } \\
\text { Criminal }\end{array}$ & $20 / 10 / 2014$ \\
\hline A51 & $\begin{array}{l}\text { Agravo em } \\
\text { Execução }\end{array}$ & $990.10 .386250-3$ & $\begin{array}{l}\text { Marco Antônio } \\
\text { Cogan }\end{array}$ & $\begin{array}{c}3^{\mathrm{a}} \\
\text { Câmara } \\
\text { Criminal }\end{array}$ & $09 / 11 / 2010$ \\
\hline A52 & $\begin{array}{l}\text { Agravo em } \\
\text { Execução }\end{array}$ & $990.10 .127158-3$ & Moreira da Silva & $\begin{array}{c}3^{\mathrm{a}} \\
\text { Câmara } \\
\text { Criminal }\end{array}$ & $23 / 11 / 2010$ \\
\hline A53 & $\begin{array}{l}\text { Agravo em } \\
\text { Execução }\end{array}$ & $\begin{array}{c}0387335- \\
38.2010 .8 .26 .0000\end{array}$ & Toloza Neto & $\begin{array}{c}3^{\mathrm{a}} \\
\text { Câmara } \\
\text { Criminal }\end{array}$ & $30 / 11 / 2010$ \\
\hline A54 & Agravo em & $990.10 .086685-0$ & Ruy Alberto & $3^{a}$ & $22 / 06 / 2010$ \\
\hline
\end{tabular}




\begin{tabular}{|c|c|c|c|c|c|}
\hline & Execução & & Leme Cavalheiro & $\begin{array}{l}\text { Câmara } \\
\text { Criminal }\end{array}$ & \\
\hline A55 & $\begin{array}{l}\text { Agravo em } \\
\text { Execução }\end{array}$ & $990.10 .027004-4$ & Geraldo Wohlers & $\begin{array}{c}3^{\mathrm{a}} \\
\text { Câmara } \\
\text { Criminal }\end{array}$ & $10 / 08 / 2010$ \\
\hline A56 & $\begin{array}{l}\text { Agravo em } \\
\text { Execução }\end{array}$ & $\begin{array}{c}0143842- \\
58.2011 .8 .26 .0000\end{array}$ & $\begin{array}{c}\text { Ruy Alberto } \\
\text { Leme Cavalheiro }\end{array}$ & $\begin{array}{c}3^{\mathrm{a}} \\
\text { Câmara } \\
\text { Criminal }\end{array}$ & $13 / 12 / 2011$ \\
\hline A57 & $\begin{array}{l}\text { Agravo em } \\
\text { Execução }\end{array}$ & $\begin{array}{c}0098895- \\
16.2011 .8 .26 .0000\end{array}$ & Toloza Neto & $\begin{array}{c}3^{\mathrm{a}} \\
\text { Câmara } \\
\text { Criminal }\end{array}$ & $22 / 11 / 2011$ \\
\hline A58 & $\begin{array}{l}\text { Agravo em } \\
\text { Execução }\end{array}$ & $\begin{array}{c}0049163- \\
66.2011 .8 .26 .0000\end{array}$ & Geraldo Wohlers & $\begin{array}{c}3^{\mathrm{a}} \\
\text { Câmara } \\
\text { Criminal }\end{array}$ & $25 / 10 / 2011$ \\
\hline A59 & $\begin{array}{l}\text { Habeas } \\
\text { Corpus }\end{array}$ & $\begin{array}{c}0214974- \\
15.2010 .8 .26 .0000\end{array}$ & Fernando Simão & $\begin{array}{c}3^{\mathrm{a}} \\
\text { Câmara } \\
\text { Criminal }\end{array}$ & $25 / 10 / 2011$ \\
\hline A60 & $\begin{array}{l}\text { Agravo em } \\
\text { Execução }\end{array}$ & $\begin{array}{c}0042203- \\
94.2011 .8 .26 .0000\end{array}$ & Luiz Pantaleão & $\begin{array}{c}3^{\mathrm{a}} \\
\text { Câmara } \\
\text { Criminal }\end{array}$ & $16 / 08 / 2011$ \\
\hline A61 & $\begin{array}{l}\text { Agravo em } \\
\text { Execução }\end{array}$ & $\begin{array}{c}0173300- \\
8.6 .2012 .8 .26 .0000\end{array}$ & $\begin{array}{c}\text { Ruy Alberto } \\
\text { Leme Cavalheiro }\end{array}$ & $\begin{array}{c}3^{\mathrm{a}} \\
\text { Câmara } \\
\text { Criminal }\end{array}$ & $11 / 12 / 2012$ \\
\hline A62 & $\begin{array}{l}\text { Agravo em } \\
\text { Execução }\end{array}$ & $\begin{array}{c}0139204- \\
45.2012 .8 .26 .0000\end{array}$ & Toloza Neto & $\begin{array}{c}3^{\mathrm{a}} \\
\text { Câmara } \\
\text { Criminal }\end{array}$ & $04 / 12 / 2012$ \\
\hline A62 & $\begin{array}{l}\text { Agravo em } \\
\text { Execução }\end{array}$ & $\begin{array}{c}0119243- \\
21.2012 .8 .26 .0000\end{array}$ & Luiz Pantaleão & $\begin{array}{c}3^{\mathrm{a}} \\
\text { Câmara } \\
\text { Criminal }\end{array}$ & $30 / 10 / 2012$ \\
\hline A63 & $\begin{array}{l}\text { Agravo em } \\
\text { Execução }\end{array}$ & $\begin{array}{c}\text { 0119697- } \\
98.2012 .8 .26 .0000\end{array}$ & Fernando Simão & $\begin{array}{c}3^{\mathrm{a}} \\
\text { Câmara } \\
\text { Criminal }\end{array}$ & $23 / 10 / 2012$ \\
\hline A64 & Agravo em & 0050327- & Fernando Simão & $3^{a}$ & $18 / 09 / 2012$ \\
\hline
\end{tabular}




\begin{tabular}{|c|c|c|c|c|c|}
\hline & Execução & 32.2012 .8 .26 .0000 & & $\begin{array}{l}\text { Câmara } \\
\text { Criminal }\end{array}$ & \\
\hline A66 & $\begin{array}{l}\text { Agravo em } \\
\text { Execução }\end{array}$ & $\begin{array}{c}0191304- \\
40.2013 .8 .26 .0000\end{array}$ & Toloza Neto & $\begin{array}{c}3^{\mathrm{a}} \\
\text { Câmara } \\
\text { Criminal }\end{array}$ & $10 / 12 / 2013$ \\
\hline A67 & $\begin{array}{l}\text { Agravo em } \\
\text { Execução }\end{array}$ & $\begin{array}{c}0190430- \\
55.2013 .8 .26 .0000\end{array}$ & Geraldo Wohlers & $\begin{array}{c}3^{\mathrm{a}} \\
\text { Câmara } \\
\text { Criminal }\end{array}$ & $10 / 12 / 2013$ \\
\hline A68 & $\begin{array}{l}\text { Agravo em } \\
\text { Execução }\end{array}$ & $\begin{array}{c}\text { 7005055- } \\
65.2013 .8 .26 .0482\end{array}$ & $\begin{array}{c}\text { Ruy Alberto } \\
\text { Leme Cavalheiro }\end{array}$ & $\begin{array}{c}3^{\mathrm{a}} \\
\text { Câmara } \\
\text { Criminal }\end{array}$ & $12 / 11 / 2013$ \\
\hline A69 & $\begin{array}{l}\text { Agravo em } \\
\text { Execução }\end{array}$ & $\begin{array}{c}7001450- \\
23.2013 .8 .26 .0576\end{array}$ & Amado de Faria & $\begin{array}{c}3^{\mathrm{a}} \\
\text { Câmara } \\
\text { Criminal }\end{array}$ & $17 / 09 / 2013$ \\
\hline A70 & $\begin{array}{l}\text { Agravo em } \\
\text { Execução }\end{array}$ & $\begin{array}{c}0072931- \\
50.2013 .8 .26 .0000\end{array}$ & Amado de Faria & $\begin{array}{c}3^{\mathrm{a}} \\
\text { Câmara } \\
\text { Criminal }\end{array}$ & $30 / 07 / 2013$ \\
\hline A71 & $\begin{array}{l}\text { Agravo em } \\
\text { Execução }\end{array}$ & $\begin{array}{c}7004155- \\
74.2014 .8 .26 .0344\end{array}$ & $\begin{array}{c}\text { Cesar Mecchi } \\
\text { Morales }\end{array}$ & $\begin{array}{c}3^{\mathrm{a}} \\
\text { Câmara } \\
\text { Criminal }\end{array}$ & $16 / 12 / 2014$ \\
\hline A72 & $\begin{array}{l}\text { Agravo em } \\
\text { Execução }\end{array}$ & $\begin{array}{c}7003713- \\
39.2013 .8 .26 .0637\end{array}$ & Toloza Neto & $\begin{array}{c}3^{\mathrm{a}} \\
\text { Câmara } \\
\text { Criminal }\end{array}$ & $16 / 12 / 2014$ \\
\hline A73 & $\begin{array}{l}\text { Agravo em } \\
\text { Execução }\end{array}$ & $\begin{array}{c}0048776- \\
46.2014 .8 .26 .0000\end{array}$ & $\begin{array}{c}\text { Cesar Mecchi } \\
\text { Morales }\end{array}$ & $\begin{array}{c}3^{\mathrm{a}} \\
\text { Câmara } \\
\text { Criminal }\end{array}$ & $14 / 10 / 2014$ \\
\hline A74 & $\begin{array}{l}\text { Agravo em } \\
\text { Execução }\end{array}$ & $\begin{array}{c}\text { 0043224- } \\
03.2014 .8 .26 .0000\end{array}$ & Geraldo Wohlers & $\begin{array}{c}3^{\mathrm{a}} \\
\text { Câmara } \\
\text { Criminal }\end{array}$ & $16 / 09 / 2014$ \\
\hline A75 & $\begin{array}{l}\text { Agravo em } \\
\text { Execução }\end{array}$ & $\begin{array}{c}\text { 7001252- } \\
66.2014 .8 .26 .0344\end{array}$ & $\begin{array}{c}\text { Ruy Alberto } \\
\text { Leme Cavalheiro }\end{array}$ & $\begin{array}{c}3^{\mathrm{a}} \\
\text { Câmara } \\
\text { Criminal }\end{array}$ & $26 / 08 / 2014$ \\
\hline A76 & Agravo em & 990.10.121311-7 & Augusto de & $4^{a}$ & $21 / 09 / 2010$ \\
\hline
\end{tabular}




\begin{tabular}{|c|c|c|c|c|c|}
\hline & Execução & & Siqueira & $\begin{array}{l}\text { Câmara } \\
\text { Criminal }\end{array}$ & \\
\hline A77 & $\begin{array}{l}\text { Agravo em } \\
\text { Execução }\end{array}$ & $990.10 .287985-2$ & $\begin{array}{l}\text { Augusto de } \\
\text { Siqueira }\end{array}$ & $\begin{array}{c}4^{\mathrm{a}} \\
\text { Câmara } \\
\text { Criminal }\end{array}$ & $26 / 10 / 2010$ \\
\hline A78 & $\begin{array}{l}\text { Agravo em } \\
\text { Execução }\end{array}$ & $990.10 .272150-7$ & Willian Campos & $\begin{array}{c}4^{\mathrm{a}} \\
\text { Câmara } \\
\text { Criminal }\end{array}$ & $28 / 09 / 2010$ \\
\hline A79 & $\begin{array}{l}\text { Agravo em } \\
\text { Execução }\end{array}$ & $\begin{array}{c}0377331- \\
39.2010 .8 .26 .0000\end{array}$ & Salles Abreu & $\begin{array}{c}4^{\mathrm{a}} \\
\text { Câmara } \\
\text { Criminal }\end{array}$ & $30 / 11 / 2010$ \\
\hline A 80 & $\begin{array}{l}\text { Agravo em } \\
\text { Execução }\end{array}$ & $990.10 .365544-3$ & Euvaldo Chaib & $\begin{array}{c}4^{\mathrm{a}} \\
\text { Câmara } \\
\text { Criminal }\end{array}$ & $16 / 11 / 2010$ \\
\hline A81 & $\begin{array}{l}\text { Agravo em } \\
\text { Execução }\end{array}$ & $\begin{array}{c}0103628- \\
25.2011 .8 .26 .0000\end{array}$ & Willian Campos & $\begin{array}{c}4^{\mathrm{a}} \\
\text { Câmara } \\
\text { Criminal }\end{array}$ & $25 / 10 / 2011$ \\
\hline A 82 & $\begin{array}{l}\text { Agravo em } \\
\text { Execução }\end{array}$ & $\begin{array}{c}0522758- \\
67.2010 .8 .26 .0000\end{array}$ & Eduardo Braga & $\begin{array}{c}4^{\mathrm{a}} \\
\text { Câmara } \\
\text { Criminal }\end{array}$ & $18 / 10 / 2011$ \\
\hline A83 & $\begin{array}{l}\text { Agravo em } \\
\text { Execução }\end{array}$ & $\begin{array}{c}0136184- \\
80.2011 .8 .26 .0000\end{array}$ & Euvaldo Chaib & $\begin{array}{c}4^{\mathrm{a}} \\
\text { Câmara } \\
\text { Criminal }\end{array}$ & $22 / 11 / 2011$ \\
\hline A84 & $\begin{array}{l}\text { Agravo em } \\
\text { Execução }\end{array}$ & $\begin{array}{c}0156530- \\
52.2011 .8 .26 .0000\end{array}$ & Salles Abreu & $\begin{array}{c}4^{\mathrm{a}} \\
\text { Câmara } \\
\text { Criminal }\end{array}$ & $13 / 12 / 2011$ \\
\hline A85 & $\begin{array}{l}\text { Agravo em } \\
\text { Execução }\end{array}$ & $\begin{array}{c}0139195- \\
20.2011 .8 .26 .0000\end{array}$ & Edison Brandão & $\begin{array}{c}4^{\mathrm{a}} \\
\text { Câmara } \\
\text { Criminal }\end{array}$ & $13 / 12 / 2011$ \\
\hline A86 & $\begin{array}{l}\text { Agravo em } \\
\text { Execução }\end{array}$ & $\begin{array}{c}\text { 0243457- } \\
21.2011 .8 .26 .0000\end{array}$ & Eduardo Braga & $\begin{array}{c}4^{\mathrm{a}} \\
\text { Câmara } \\
\text { Criminal }\end{array}$ & $07 / 08 / 2012$ \\
\hline A87 & Agravo em & 0046312- & Euvaldo Chaib & $4^{a}$ & $21 / 08 / 2012$ \\
\hline
\end{tabular}




\begin{tabular}{|c|c|c|c|c|c|}
\hline & Execução & 20.2012.8.26.0000 & & $\begin{array}{l}\text { Câmara } \\
\text { Criminal }\end{array}$ & \\
\hline A88 & $\begin{array}{l}\text { Agravo em } \\
\text { Execução }\end{array}$ & $\begin{array}{c}0012545- \\
88.2012 .8 .26 .0000\end{array}$ & Eduardo Braga & $\begin{array}{c}4^{\mathrm{a}} \\
\text { Câmara } \\
\text { Criminal }\end{array}$ & $06 / 11 / 2012$ \\
\hline A89 & $\begin{array}{l}\text { Agravo em } \\
\text { Execução }\end{array}$ & $\begin{array}{c}0119613- \\
97.2012 .8 .26 .0000\end{array}$ & Willian Campos & $\begin{array}{c}4^{\mathrm{a}} \\
\text { Câmara } \\
\text { Criminal }\end{array}$ & $04 / 12 / 2012$ \\
\hline A90 & $\begin{array}{l}\text { Agravo em } \\
\text { Execução }\end{array}$ & $\begin{array}{c}0135672- \\
63.2012 .8 .26 .0000\end{array}$ & Edison Brandão & $\begin{array}{c}4^{\mathrm{a}} \\
\text { Câmara } \\
\text { Criminal }\end{array}$ & $04 / 12 / 2012$ \\
\hline A91 & $\begin{array}{l}\text { Agravo em } \\
\text { Execução }\end{array}$ & $\begin{array}{c}0046953- \\
71.2013 .8 .26 .0000\end{array}$ & $\begin{array}{c}\text { Laerte Marrone } \\
\text { de Castro } \\
\text { Sampaio }\end{array}$ & $\begin{array}{c}4^{\mathrm{a}} \\
\text { Câmara } \\
\text { Criminal }\end{array}$ & $11 / 06 / 2013$ \\
\hline A92 & $\begin{array}{l}\text { Agravo em } \\
\text { Execução }\end{array}$ & $\begin{array}{c}0119987- \\
16.2012 .8 .26 .0000\end{array}$ & Willian Campos & $\begin{array}{c}4^{\mathrm{a}} \\
\text { Câmara } \\
\text { Criminal }\end{array}$ & $10 / 09 / 2013$ \\
\hline A93 & $\begin{array}{l}\text { Agravo em } \\
\text { Execução }\end{array}$ & $\begin{array}{c}0157630- \\
71.2013 .8 .26 .0000\end{array}$ & $\begin{array}{l}\text { Luis Soares de } \\
\text { Mello }\end{array}$ & $\begin{array}{c}4^{\mathrm{a}} \\
\text { Câmara } \\
\text { Criminal }\end{array}$ & $26 / 11 / 2013$ \\
\hline A94 & $\begin{array}{l}\text { Agravo em } \\
\text { Execução }\end{array}$ & $\begin{array}{c}\text { 7011486- } \\
\text { 18.2013.8.26.0482 }\end{array}$ & Ivana David & $\begin{array}{c}4^{\mathrm{a}} \\
\text { Câmara } \\
\text { Criminal }\end{array}$ & $10 / 12 / 2013$ \\
\hline A95 & $\begin{array}{l}\text { Agravo em } \\
\text { Execução }\end{array}$ & $\begin{array}{c}\text { 0184116- } \\
93.2013 .8 .26 .0000\end{array}$ & Edison Brandão & $\begin{array}{c}4^{\mathrm{a}} \\
\text { Câmara } \\
\text { Criminal }\end{array}$ & $10 / 12 / 2013$ \\
\hline A96 & $\begin{array}{l}\text { Agravo em } \\
\text { Execução }\end{array}$ & $\begin{array}{c}0064423- \\
81.2014 .8 .26 .0000\end{array}$ & Ivan Sartori & $\begin{array}{c}4^{\mathrm{a}} \\
\text { Câmara } \\
\text { Criminal }\end{array}$ & $11 / 11 / 2014$ \\
\hline A97 & $\begin{array}{l}\text { Agravo em } \\
\text { Execução }\end{array}$ & $\begin{array}{c}\text { 7014004- } \\
\text { 78.2013.8.26.0482 }\end{array}$ & Willian Campos & $\begin{array}{c}4^{\mathrm{a}} \\
\text { Câmara } \\
\text { Criminal }\end{array}$ & $25 / 11 / 2014$ \\
\hline A98 & Agravo em & 0065183- & Luis Soares de & $4^{a}$ & $02 / 12 / 2014$ \\
\hline
\end{tabular}




\begin{tabular}{|c|c|c|c|c|c|}
\hline & Execução & 30.2014 .8 .26 .0000 & Mello & $\begin{array}{l}\text { Câmara } \\
\text { Criminal }\end{array}$ & \\
\hline A99 & $\begin{array}{l}\text { Agravo em } \\
\text { Execução }\end{array}$ & $\begin{array}{c}\text { 7005776- } \\
\text { 37.2013.8.26.0637 }\end{array}$ & Edison Brandão & $\begin{array}{c}4^{\mathrm{a}} \\
\text { Câmara } \\
\text { Criminal }\end{array}$ & $02 / 12 / 2014$ \\
\hline A100 & $\begin{array}{l}\text { Agravo em } \\
\text { Execução }\end{array}$ & $\begin{array}{c}\text { 0065859- } \\
75.2014 .8 .26 .0000\end{array}$ & Camilo Léllis & $\begin{array}{c}4^{\mathrm{a}} \\
\text { Câmara } \\
\text { Criminal }\end{array}$ & $16 / 12 / 2014$ \\
\hline A101 & $\begin{array}{l}\text { Agravo em } \\
\text { Execução }\end{array}$ & $990.09 .340561-0$ & Sérgio Ribas & $\begin{array}{c}5^{\mathrm{a}} \\
\text { Câmara } \\
\text { Criminal }\end{array}$ & 05/08/2010 \\
\hline A102 & $\begin{array}{l}\text { Agravo em } \\
\text { Execução }\end{array}$ & $990.10 .424582-6$ & Juvenal Duarte & $\begin{array}{c}5^{\mathrm{a}} \\
\text { Câmara } \\
\text { Criminal }\end{array}$ & $09 / 12 / 2010$ \\
\hline A103 & $\begin{array}{l}\text { Agravo em } \\
\text { Execução }\end{array}$ & $990.10 .053382-7$ & $\begin{array}{l}\text { Luís Carlos de } \\
\text { Souza Lourenço }\end{array}$ & $\begin{array}{c}5^{\mathrm{a}} \\
\text { Câmara } \\
\text { Criminal }\end{array}$ & $23 / 09 / 2010$ \\
\hline A104 & $\begin{array}{l}\text { Agravo em } \\
\text { Execução }\end{array}$ & $990.10 .244981-5$ & $\begin{array}{c}\text { José Damião } \\
\text { Pinheiro Machado } \\
\text { Cogan }\end{array}$ & $\begin{array}{c}5^{\mathrm{a}} \\
\text { Câmara } \\
\text { Criminal }\end{array}$ & $02 / 12 / 2010$ \\
\hline A105 & $\begin{array}{l}\text { Agravo em } \\
\text { Execução }\end{array}$ & $990.10 .438975-5$ & Pinheiro Franco & $\begin{array}{c}5^{\mathrm{a}} \\
\text { Câmara } \\
\text { Criminal }\end{array}$ & $16 / 12 / 2010$ \\
\hline A106 & $\begin{array}{l}\text { Agravo em } \\
\text { Execução }\end{array}$ & $\begin{array}{c}0182247- \\
71.2008 .8 .26 .0000\end{array}$ & $\begin{array}{c}\text { José Damião } \\
\text { Pinheiro Machado } \\
\text { Cogan }\end{array}$ & $\begin{array}{c}5^{\mathrm{a}} \\
\text { Câmara } \\
\text { Criminal }\end{array}$ & $22 / 09 / 2011$ \\
\hline A107 & $\begin{array}{l}\text { Agravo em } \\
\text { Execução }\end{array}$ & $\begin{array}{c}\text { 0156645- } \\
\text { 73.2011.8.26.0000 }\end{array}$ & Juvenal Duarte & $\begin{array}{c}5^{\mathrm{a}} \\
\text { Câmara } \\
\text { Criminal }\end{array}$ & $10 / 11 / 2011$ \\
\hline A108 & $\begin{array}{l}\text { Agravo em } \\
\text { Execução }\end{array}$ & $\begin{array}{c}0094396- \\
86.2011 .8 .26 .0000\end{array}$ & Pinheiro Franco & $\begin{array}{c}5^{\mathrm{a}} \\
\text { Câmara } \\
\text { Criminal }\end{array}$ & $13 / 10 / 2011$ \\
\hline A109 & Agravo em & 0179262- & Tristão Ribeiro & $5^{a}$ & $15 / 12 / 2011$ \\
\hline
\end{tabular}




\begin{tabular}{|c|c|c|c|c|c|}
\hline & Execução & 27.2011.8.26.0000 & & $\begin{array}{l}\text { Câmara } \\
\text { Criminal }\end{array}$ & \\
\hline A110 & $\begin{array}{l}\text { Agravo em } \\
\text { Execução }\end{array}$ & $\begin{array}{c}0153231- \\
67.2011 .8 .26 .0000\end{array}$ & Sérgio Ribas & $\begin{array}{c}5^{\mathrm{a}} \\
\text { Câmara } \\
\text { Criminal }\end{array}$ & $15 / 12 / 2011$ \\
\hline A111 & $\begin{array}{l}\text { Agravo em } \\
\text { Execução }\end{array}$ & $\begin{array}{c}0100725- \\
80.2012 .8 .26 .0000\end{array}$ & Sérgio Ribas & $\begin{array}{c}5^{\mathrm{a}} \\
\text { Câmara } \\
\text { Criminal }\end{array}$ & $25 / 10 / 2012$ \\
\hline A112 & $\begin{array}{l}\text { Agravo em } \\
\text { Execução }\end{array}$ & $\begin{array}{c}0173550- \\
22.2012 .8 .26 .0000\end{array}$ & Juvenal Duarte & $\begin{array}{c}5^{\mathrm{a}} \\
\text { Câmara } \\
\text { Criminal }\end{array}$ & $01 / 11 / 2012$ \\
\hline A113 & $\begin{array}{l}\text { Agravo em } \\
\text { Execução }\end{array}$ & $\begin{array}{c}0203483- \\
40.2012 .8 .26 .0000\end{array}$ & Juvenal Duarte & $\begin{array}{c}5^{\mathrm{a}} \\
\text { Câmara } \\
\text { Criminal }\end{array}$ & $06 / 12 / 2012$ \\
\hline A114 & $\begin{array}{l}\text { Agravo em } \\
\text { Execução }\end{array}$ & $\begin{array}{c}0182734- \\
02.2012 .8 .26 .0000\end{array}$ & $\begin{array}{l}\text { Aguinaldo de } \\
\text { Freitas Filho }\end{array}$ & $\begin{array}{c}5^{\mathrm{a}} \\
\text { Câmara } \\
\text { Criminal }\end{array}$ & $13 / 12 / 2012$ \\
\hline A115 & $\begin{array}{l}\text { Agravo em } \\
\text { Execução }\end{array}$ & $\begin{array}{c}\text { 0205099- } \\
50.2012 .8 .26 .0000\end{array}$ & Sérgio Ribas & $\begin{array}{c}5^{\mathrm{a}} \\
\text { Câmara } \\
\text { Criminal }\end{array}$ & $13 / 12 / 2012$ \\
\hline A116 & $\begin{array}{l}\text { Agravo em } \\
\text { Execução }\end{array}$ & $\begin{array}{c}0005843- \\
92.2013 .8 .26 .0000\end{array}$ & $\begin{array}{l}\text { Aguinaldo de } \\
\text { Freitas Filho }\end{array}$ & $\begin{array}{c}5^{\mathrm{a}} \\
\text { Câmara } \\
\text { Criminal }\end{array}$ & $25 / 04 / 2013$ \\
\hline A117 & $\begin{array}{l}\text { Habeas } \\
\text { Corpus }\end{array}$ & $\begin{array}{c}\text { 0084977- } \\
\text { 71.2013.8.26.0000 }\end{array}$ & $\begin{array}{c}\text { José Damião } \\
\text { Pinheiro Machado } \\
\text { Cogan }\end{array}$ & $\begin{array}{c}5^{\mathrm{a}} \\
\text { Câmara } \\
\text { Criminal }\end{array}$ & $01 / 08 / 2013$ \\
\hline A118 & $\begin{array}{l}\text { Agravo em } \\
\text { Execução }\end{array}$ & $\begin{array}{c}0153387- \\
84.2013 .8 .26 .0000\end{array}$ & Pinheiro Franco & $\begin{array}{c}5^{\mathrm{a}} \\
\text { Câmara } \\
\text { Criminal }\end{array}$ & $17 / 10 / 2013$ \\
\hline A119 & $\begin{array}{l}\text { Agravo em } \\
\text { Execução }\end{array}$ & $\begin{array}{c}0182362- \\
19.2013 .8 .26 .0000\end{array}$ & Juvenal Duarte & $\begin{array}{c}5^{\mathrm{a}} \\
\text { Câmara } \\
\text { Criminal }\end{array}$ & $28 / 11 / 2013$ \\
\hline A120 & Agravo em & 0187331- & Sérgio Ribas & $5^{a}$ & $12 / 12 / 2013$ \\
\hline
\end{tabular}




\begin{tabular}{|c|c|c|c|c|c|}
\hline & Execução & 77.2013.8.26.0000 & & $\begin{array}{l}\text { Câmara } \\
\text { Criminal }\end{array}$ & \\
\hline A121 & $\begin{array}{l}\text { Agravo em } \\
\text { Execução }\end{array}$ & $\begin{array}{c}\text { 0020629- } \\
10.2014 .8 .26 .0000\end{array}$ & Juvenal Duarte & $\begin{array}{c}5^{\mathrm{a}} \\
\text { Câmara } \\
\text { Criminal }\end{array}$ & $24 / 07 / 2014$ \\
\hline A122 & $\begin{array}{l}\text { Agravo em } \\
\text { Execução }\end{array}$ & $\begin{array}{c}7003051- \\
12.2012 .8 .26 .0637\end{array}$ & Tristão Ribeiro & $\begin{array}{c}5^{\mathrm{a}} \\
\text { Câmara } \\
\text { Criminal }\end{array}$ & $02 / 10 / 2014$ \\
\hline A123 & $\begin{array}{l}\text { Agravo em } \\
\text { Execução }\end{array}$ & $\begin{array}{c}0054105- \\
39.2014 .8 .26 .0000\end{array}$ & Sérgio Ribas & $\begin{array}{c}5^{\mathrm{a}} \\
\text { Câmara } \\
\text { Criminal }\end{array}$ & $16 / 10 / 2014$ \\
\hline A124 & $\begin{array}{l}\text { Agravo em } \\
\text { Execução }\end{array}$ & $\begin{array}{c}7000448- \\
22.2013 .8 .26 .0510\end{array}$ & Juvenal Duarte & $\begin{array}{c}5^{\mathrm{a}} \\
\text { Câmara } \\
\text { Criminal }\end{array}$ & $13 / 11 / 2014$ \\
\hline A125 & $\begin{array}{l}\text { Agravo em } \\
\text { Execução }\end{array}$ & $\begin{array}{c}0039971- \\
07.2014 .8 .26 .0000\end{array}$ & $\begin{array}{c}\text { José Damião } \\
\text { Pinheiro Machado } \\
\text { Cogan }\end{array}$ & $\begin{array}{c}5^{\mathrm{a}} \\
\text { Câmara } \\
\text { Criminal }\end{array}$ & $27 / 11 / 2014$ \\
\hline A126 & $\begin{array}{l}\text { Agravo em } \\
\text { Execução }\end{array}$ & 990.09.193476-3 & Ericson Maranho & $\begin{array}{c}6^{\mathrm{a}} \\
\text { Câmara } \\
\text { Criminal }\end{array}$ & $12 / 08 / 2010$ \\
\hline A127 & $\begin{array}{l}\text { Habeas } \\
\text { Corpus }\end{array}$ & $990.10 .486175-6$ & $\begin{array}{c}\text { José Raul Gavião } \\
\text { de Almeida }\end{array}$ & $\begin{array}{c}6^{\mathrm{a}} \\
\text { Câmara } \\
\text { Criminal }\end{array}$ & $28 / 10 / 2010$ \\
\hline A128 & $\begin{array}{l}\text { Agravo em } \\
\text { Execução }\end{array}$ & $990.10 .380003-6$ & $\begin{array}{c}\text { Machado de } \\
\text { Andrade }\end{array}$ & $\begin{array}{c}6^{\mathrm{a}} \\
\text { Câmara } \\
\text { Criminal }\end{array}$ & $25 / 11 / 2010$ \\
\hline A129 & $\begin{array}{l}\text { Agravo em } \\
\text { Execução }\end{array}$ & $990.10 .294706-8$ & $\begin{array}{l}\text { Marco Antonio } \\
\text { Marques da Silva }\end{array}$ & $\begin{array}{c}6^{\mathrm{a}} \\
\text { Câmara } \\
\text { Criminal }\end{array}$ & $25 / 11 / 2010$ \\
\hline A130 & $\begin{array}{l}\text { Agravo em } \\
\text { Execução }\end{array}$ & $990.10 .387830-2$ & $\begin{array}{c}\text { Ricardo } \\
\text { Tucunduva }\end{array}$ & $\begin{array}{c}6^{\mathrm{a}} \\
\text { Câmara } \\
\text { Criminal }\end{array}$ & $16 / 12 / 2010$ \\
\hline A131 & Agravo em & 0079399- & Ericson Maranho & $6^{\mathrm{a}}$ & $20 / 10 / 2011$ \\
\hline
\end{tabular}




\begin{tabular}{|c|c|c|c|c|c|}
\hline & Execução & 98.2011 .8 .26 .0000 & & $\begin{array}{l}\text { Câmara } \\
\text { Criminal }\end{array}$ & \\
\hline A132 & $\begin{array}{l}\text { Agravo em } \\
\text { Execução }\end{array}$ & $\begin{array}{c}0110342- \\
98.2011 .8 .26 .0000\end{array}$ & Silmar Fernandes & $\begin{array}{c}6^{\mathrm{a}} \\
\text { Câmara } \\
\text { Criminal }\end{array}$ & $10 / 11 / 2011$ \\
\hline A133 & $\begin{array}{l}\text { Agravo em } \\
\text { Execução }\end{array}$ & $\begin{array}{c}\text { 0178479- } \\
35.2011 .8 .26 .0000\end{array}$ & $\begin{array}{l}\text { Marco Antonio } \\
\text { Marques da Silva }\end{array}$ & $\begin{array}{c}6^{\mathrm{a}} \\
\text { Câmara } \\
\text { Criminal }\end{array}$ & $01 / 12 / 2011$ \\
\hline A134 & $\begin{array}{l}\text { Agravo em } \\
\text { Execução }\end{array}$ & $\begin{array}{c}0419536- \\
83.2010 .8 .26 .0000\end{array}$ & $\begin{array}{c}\text { José Raul Gavião } \\
\text { de Almeida }\end{array}$ & $\begin{array}{c}6^{\mathrm{a}} \\
\text { Câmara } \\
\text { Criminal }\end{array}$ & $01 / 12 / 2011$ \\
\hline A135 & $\begin{array}{l}\text { Agravo em } \\
\text { Execução }\end{array}$ & $\begin{array}{c}0174534- \\
40.2011 .8 .26 .0000\end{array}$ & $\begin{array}{c}\text { Ricardo } \\
\text { Tucunduva }\end{array}$ & $\begin{array}{c}6^{\mathrm{a}} \\
\text { Câmara } \\
\text { Criminal }\end{array}$ & $01 / 12 / 2011$ \\
\hline A136 & $\begin{array}{l}\text { Agravo em } \\
\text { Execução }\end{array}$ & $\begin{array}{c}0056582- \\
06.2012 .8 .26 .0000\end{array}$ & Silmar Fernandes & $\begin{array}{c}6^{\mathrm{a}} \\
\text { Câmara } \\
\text { Criminal }\end{array}$ & 09/08/2012 \\
\hline A137 & $\begin{array}{l}\text { Agravo em } \\
\text { Execução }\end{array}$ & $\begin{array}{c}0147970- \\
87.2012 .8 .26 .0000\end{array}$ & $\begin{array}{c}\text { José Raul Gavião } \\
\text { de Almeida }\end{array}$ & $\begin{array}{c}6^{\mathrm{a}} \\
\text { Câmara } \\
\text { Criminal }\end{array}$ & $18 / 10 / 2012$ \\
\hline A138 & $\begin{array}{l}\text { Agravo em } \\
\text { Execução }\end{array}$ & $\begin{array}{c}0189978- \\
79.2012 .8 .26 .0000\end{array}$ & $\begin{array}{c}\text { Marco Antonio } \\
\text { Marques da Silva }\end{array}$ & $\begin{array}{c}6^{\mathrm{a}} \\
\text { Câmara } \\
\text { Criminal }\end{array}$ & $06 / 12 / 2012$ \\
\hline A139 & $\begin{array}{l}\text { Agravo em } \\
\text { Execução }\end{array}$ & $\begin{array}{c}\text { 0195107- } \\
65.2012 .8 .26 .0000\end{array}$ & $\begin{array}{c}\text { Machado de } \\
\text { Andrade }\end{array}$ & $\begin{array}{c}6^{\mathrm{a}} \\
\text { Câmara } \\
\text { Criminal }\end{array}$ & $06 / 12 / 2012$ \\
\hline A140 & $\begin{array}{l}\text { Agravo em } \\
\text { Execução }\end{array}$ & $\begin{array}{c}0157257- \\
74.2012 .8 .26 .0000\end{array}$ & $\begin{array}{c}\text { Ricardo } \\
\text { Tucunduva }\end{array}$ & $\begin{array}{c}6^{\mathrm{a}} \\
\text { Câmara } \\
\text { Criminal }\end{array}$ & $13 / 12 / 2012$ \\
\hline A141 & $\begin{array}{l}\text { Agravo em } \\
\text { Execução }\end{array}$ & $\begin{array}{c}\text { 0179424- } \\
51.2013 .8 .26 .0000\end{array}$ & $\begin{array}{l}\text { Marco Antonio } \\
\text { Marques da Silva }\end{array}$ & $\begin{array}{c}6^{\mathrm{a}} \\
\text { Câmara } \\
\text { Criminal }\end{array}$ & $19 / 12 / 2013$ \\
\hline A142 & Agravo em & 0173234- & José Raul Gavião & $6^{\mathrm{a}}$ & $05 / 12 / 2013$ \\
\hline
\end{tabular}




\begin{tabular}{|c|c|c|c|c|c|}
\hline & Execução & 72.2013.8.26.0000 & de Almeida & $\begin{array}{l}\text { Câmara } \\
\text { Criminal }\end{array}$ & \\
\hline A143 & $\begin{array}{l}\text { Agravo em } \\
\text { Execução }\end{array}$ & $\begin{array}{c}0159334- \\
22.2013 .8 .26 .0000\end{array}$ & $\begin{array}{c}\text { Ricardo } \\
\text { Tucunduva }\end{array}$ & $\begin{array}{c}6^{\mathrm{a}} \\
\text { Câmara } \\
\text { Criminal }\end{array}$ & $14 / 11 / 2013$ \\
\hline A144 & $\begin{array}{l}\text { Agravo em } \\
\text { Execução }\end{array}$ & $\begin{array}{c}0155125- \\
10.2013 .8 .26 .0000\end{array}$ & $\begin{array}{c}\text { Machado de } \\
\text { Andrade }\end{array}$ & $\begin{array}{c}6^{\mathrm{a}} \\
\text { Câmara } \\
\text { Criminal }\end{array}$ & $14 / 11 / 2013$ \\
\hline A145 & $\begin{array}{l}\text { Agravo em } \\
\text { Execução }\end{array}$ & $\begin{array}{c}0152118- \\
44.2012 .8 .26 .0000\end{array}$ & Ericson Maranho & $\begin{array}{c}6^{\mathrm{a}} \\
\text { Câmara } \\
\text { Criminal }\end{array}$ & $29 / 08 / 2013$ \\
\hline A146 & $\begin{array}{l}\text { Agravo em } \\
\text { Execução }\end{array}$ & $\begin{array}{c}\text { 7011373- } \\
\text { 64.2013.8.26.0482 }\end{array}$ & $\begin{array}{l}\text { Marco Antonio } \\
\text { Marques da Silva }\end{array}$ & $\begin{array}{c}6^{\mathrm{a}} \\
\text { Câmara } \\
\text { Criminal }\end{array}$ & $11 / 12 / 2014$ \\
\hline A147 & $\begin{array}{l}\text { Agravo em } \\
\text { Execução }\end{array}$ & $\begin{array}{c}0063228- \\
61.2014 .8 .26 .0000\end{array}$ & $\begin{array}{c}\text { Machado de } \\
\text { Andrade }\end{array}$ & $\begin{array}{c}6^{\mathrm{a}} \\
\text { Câmara } \\
\text { Criminal }\end{array}$ & $27 / 11 / 2014$ \\
\hline A148 & $\begin{array}{l}\text { Agravo em } \\
\text { Execução }\end{array}$ & $\begin{array}{c}0045357- \\
18.2014 .8 .26 .0000\end{array}$ & $\begin{array}{c}\text { Ricardo } \\
\text { Tucunduva }\end{array}$ & $\begin{array}{c}6^{\mathrm{a}} \\
\text { Câmara } \\
\text { Criminal }\end{array}$ & $27 / 11 / 2014$ \\
\hline A149 & $\begin{array}{l}\text { Agravo em } \\
\text { Execução }\end{array}$ & $\begin{array}{c}\text { 0047182- } \\
94.2014 .8 .26 .0000\end{array}$ & $\begin{array}{c}\text { José Raul Gavião } \\
\text { de Almeida }\end{array}$ & $\begin{array}{c}6^{\mathrm{a}} \\
\text { Câmara } \\
\text { Criminal }\end{array}$ & $13 / 11 / 2014$ \\
\hline A150 & $\begin{array}{l}\text { Agravo em } \\
\text { Execução }\end{array}$ & $\begin{array}{c}7002635- \\
16.2013 .8 .26 .0344\end{array}$ & $\begin{array}{c}\text { Ricardo } \\
\text { Tucunduva }\end{array}$ & $\begin{array}{c}6^{\mathrm{a}} \\
\text { Câmara } \\
\text { Criminal }\end{array}$ & $13 / 02 / 2014$ \\
\hline A151 & $\begin{array}{l}\text { Habeas } \\
\text { Corpus }\end{array}$ & $990.10 .378092-2$ & Francisco Menin & $\begin{array}{c}7^{\mathrm{a}} \\
\text { Câmara } \\
\text { Criminal }\end{array}$ & $25 / 11 / 2010$ \\
\hline A152 & $\begin{array}{l}\text { Habeas } \\
\text { Corpus }\end{array}$ & 990.10.269973-0 & $\begin{array}{l}\text { Fernando } \\
\text { Miranda }\end{array}$ & $\begin{array}{c}7^{\mathrm{a}} \\
\text { Câmara } \\
\text { Criminal }\end{array}$ & $23 / 09 / 2010$ \\
\hline A153 & Agravo em & 990.09.208239-6 & Francisco Menin & $7^{a}$ & $29 / 07 / 2010$ \\
\hline
\end{tabular}




\begin{tabular}{|c|c|c|c|c|c|}
\hline & Execução & & & $\begin{array}{l}\text { Câmara } \\
\text { Criminal }\end{array}$ & \\
\hline A154 & $\begin{array}{l}\text { Agravo em } \\
\text { Execução }\end{array}$ & $990.10 .085435-6$ & Cláudio Caldeira & $\begin{array}{c}7^{\mathrm{a}} \\
\text { Câmara } \\
\text { Criminal }\end{array}$ & $12 / 08 / 2010$ \\
\hline A155 & $\begin{array}{l}\text { Agravo em } \\
\text { Execução }\end{array}$ & $990.10 .076142-0$ & $\begin{array}{l}\text { Sydnei de } \\
\text { Oliveira Jr. }\end{array}$ & $\begin{array}{c}7^{\mathrm{a}} \\
\text { Câmara } \\
\text { Criminal }\end{array}$ & $12 / 08 / 2010$ \\
\hline A156 & $\begin{array}{l}\text { Agravo em } \\
\text { Execução }\end{array}$ & $\begin{array}{c}0576411- \\
81.2010 .8 .26 .0000\end{array}$ & Cláudio Caldeira & $\begin{array}{c}7^{\mathrm{a}} \\
\text { Câmara } \\
\text { Criminal }\end{array}$ & $02 / 06 / 2011$ \\
\hline A157 & $\begin{array}{l}\text { Agravo em } \\
\text { Execução }\end{array}$ & $\begin{array}{c}0078713- \\
09.2011 .8 .26 .0000\end{array}$ & Christiano Kuntz & $\begin{array}{c}7^{\mathrm{a}} \\
\text { Câmara } \\
\text { Criminal }\end{array}$ & $18 / 08 / 2011$ \\
\hline A158 & $\begin{array}{l}\text { Habeas } \\
\text { Corpus }\end{array}$ & $\begin{array}{c}0163076- \\
26.2011 .8 .26 .0000\end{array}$ & Francisco Menin & $\begin{array}{c}7^{\mathrm{a}} \\
\text { Câmara } \\
\text { Criminal }\end{array}$ & $25 / 08 / 2011$ \\
\hline A159 & $\begin{array}{l}\text { Agravo em } \\
\text { Execução }\end{array}$ & $\begin{array}{c}0078318- \\
17.2011 .8 .26 .0000\end{array}$ & Roberto Mortari & $\begin{array}{c}7^{\mathrm{a}} \\
\text { Câmara } \\
\text { Criminal }\end{array}$ & $15 / 09 / 2011$ \\
\hline A160 & $\begin{array}{l}\text { Agravo em } \\
\text { Execução }\end{array}$ & $\begin{array}{c}\text { 0067893- } \\
28.2011 .8 .26 .0000\end{array}$ & $\begin{array}{l}\text { Sydnei de } \\
\text { Oliveira Jr. }\end{array}$ & $\begin{array}{c}7^{\mathrm{a}} \\
\text { Câmara } \\
\text { Criminal }\end{array}$ & $20 / 10 / 2011$ \\
\hline A161 & $\begin{array}{l}\text { Agravo em } \\
\text { Execução }\end{array}$ & $\begin{array}{c}0108156- \\
68.2012 .8 .26 .0000\end{array}$ & $\begin{array}{l}\text { Fernando } \\
\text { Miranda }\end{array}$ & $\begin{array}{c}7^{\mathrm{a}} \\
\text { Câmara } \\
\text { Criminal }\end{array}$ & $22 / 11 / 2012$ \\
\hline A162 & $\begin{array}{l}\text { Agravo em } \\
\text { Execução }\end{array}$ & $\begin{array}{c}0038935- \\
95.2012 .8 .26 .0000\end{array}$ & Francisco Menin & $\begin{array}{c}7^{\mathrm{a}} \\
\text { Câmara } \\
\text { Criminal }\end{array}$ & $02 / 08 / 2012$ \\
\hline A163 & $\begin{array}{l}\text { Agravo em } \\
\text { Execução }\end{array}$ & $\begin{array}{c}0112827- \\
37.2012 .8 .26 .0000\end{array}$ & Christiano Kuntz & $\begin{array}{c}7^{\mathrm{a}} \\
\text { Câmara } \\
\text { Criminal }\end{array}$ & $30 / 08 / 2012$ \\
\hline A164 & Agravo em & 0172396- & Sydnei de & $7^{a}$ & $04 / 10 / 2012$ \\
\hline
\end{tabular}




\begin{tabular}{|c|c|c|c|c|c|}
\hline & Execução & 66.2012.8.26.0000 & Oliveira Jr. & $\begin{array}{l}\text { Câmara } \\
\text { Criminal }\end{array}$ & \\
\hline A165 & $\begin{array}{l}\text { Agravo em } \\
\text { Execução }\end{array}$ & $\begin{array}{c}0182125- \\
19.2012 .8 .26 .0000\end{array}$ & Roberto Mortari & $\begin{array}{c}7^{\mathrm{a}} \\
\text { Câmara } \\
\text { Criminal }\end{array}$ & $29 / 11 / 2012$ \\
\hline A166 & $\begin{array}{l}\text { Agravo em } \\
\text { Execução }\end{array}$ & $\begin{array}{c}\text { 0197749- } \\
11.2012 .8 .26 .0000\end{array}$ & Roberto Mortari & $\begin{array}{c}7^{\mathrm{a}} \\
\text { Câmara } \\
\text { Criminal }\end{array}$ & $21 / 03 / 2013$ \\
\hline A167 & $\begin{array}{l}\text { Agravo em } \\
\text { Execução }\end{array}$ & $\begin{array}{c}0108467- \\
25.2013 .8 .26 .0000\end{array}$ & Roberto Mortari & $\begin{array}{c}7^{\mathrm{a}} \\
\text { Câmara } \\
\text { Criminal }\end{array}$ & $15 / 08 / 2013$ \\
\hline A168 & $\begin{array}{l}\text { Agravo em } \\
\text { Execução }\end{array}$ & $\begin{array}{c}0101598- \\
46.2013 .8 .26 .0000\end{array}$ & $\begin{array}{l}\text { Sydnei de } \\
\text { Oliveira Jr. }\end{array}$ & $\begin{array}{c}7^{\mathrm{a}} \\
\text { Câmara } \\
\text { Criminal }\end{array}$ & $26 / 09 / 2013$ \\
\hline A169 & $\begin{array}{l}\text { Agravo em } \\
\text { Execução }\end{array}$ & $\begin{array}{c}0116817- \\
02.2013 .8 .26 .0000\end{array}$ & Grassi Neto & $\begin{array}{c}7^{\mathrm{a}} \\
\text { Câmara } \\
\text { Criminal }\end{array}$ & $07 / 11 / 2013$ \\
\hline A170 & $\begin{array}{l}\text { Agravo em } \\
\text { Execução }\end{array}$ & $\begin{array}{c}0168941- \\
59.2013 .8 .26 .0000\end{array}$ & Francisco Menin & $\begin{array}{c}7^{\mathrm{a}} \\
\text { Câmara } \\
\text { Criminal }\end{array}$ & $07 / 11 / 2013$ \\
\hline A171 & $\begin{array}{l}\text { Agravo em } \\
\text { Execução }\end{array}$ & $\begin{array}{c}0013757- \\
76.2014 .8 .26 .0000\end{array}$ & Camilo Léllis & $\begin{array}{c}7^{\mathrm{a}} \\
\text { Câmara } \\
\text { Criminal }\end{array}$ & $31 / 07 / 2014$ \\
\hline A172 & $\begin{array}{l}\text { Agravo em } \\
\text { Execução }\end{array}$ & $\begin{array}{c}0053888- \\
93.2014 .8 .26 .0000\end{array}$ & Fernando Simão & $\begin{array}{c}7^{\mathrm{a}} \\
\text { Câmara } \\
\text { Criminal }\end{array}$ & $16 / 10 / 2014$ \\
\hline A173 & $\begin{array}{l}\text { Agravo em } \\
\text { Execução }\end{array}$ & $\begin{array}{c}7009960- \\
79.2014 .8 .26 .0482\end{array}$ & Amaro Thomé & $\begin{array}{c}7^{\mathrm{a}} \\
\text { Câmara } \\
\text { Criminal }\end{array}$ & $27 / 11 / 2014$ \\
\hline A174 & $\begin{array}{l}\text { Agravo em } \\
\text { Execução }\end{array}$ & $\begin{array}{c}0063591- \\
48.2014 .8 .26 .0000\end{array}$ & J. Martins & $\begin{array}{c}7^{\mathrm{a}} \\
\text { Câmara } \\
\text { Criminal }\end{array}$ & $04 / 12 / 2014$ \\
\hline A175 & Agravo em & 0049994- & Roberto Mortari & $7^{a}$ & $11 / 12 / 2014$ \\
\hline
\end{tabular}




\begin{tabular}{|c|c|c|c|c|c|}
\hline & Execução & 12.2014.8.26.0000 & & $\begin{array}{l}\text { Câmara } \\
\text { Criminal }\end{array}$ & \\
\hline A176 & $\begin{array}{l}\text { Agravo em } \\
\text { Execução }\end{array}$ & $990.09 .336928-1$ & Salles Vieira & $\begin{array}{c}8^{\mathrm{a}} \\
\text { Câmara } \\
\text { Criminal }\end{array}$ & $10 / 06 / 2010$ \\
\hline A177 & $\begin{array}{l}\text { Agravo em } \\
\text { Execução }\end{array}$ & $990.10 .163457-0$ & Eduardo Braga & $\begin{array}{c}8^{\mathrm{a}} \\
\text { Câmara } \\
\text { Criminal }\end{array}$ & $29 / 07 / 2010$ \\
\hline A178 & $\begin{array}{l}\text { Agravo em } \\
\text { Execução }\end{array}$ & $990.10 .154586-1$ & $\begin{array}{c}\text { Aben-Athar } \\
\text { (Paiva Coutinho) }\end{array}$ & $\begin{array}{c}8^{\mathrm{a}} \\
\text { Câmara } \\
\text { Criminal }\end{array}$ & $16 / 09 / 2010$ \\
\hline A179 & $\begin{array}{l}\text { Agravo em } \\
\text { Execução }\end{array}$ & $990.10 .336631-0$ & Poças Leitão & $\begin{array}{c}8^{\mathrm{a}} \\
\text { Câmara } \\
\text { Criminal }\end{array}$ & $21 / 10 / 2010$ \\
\hline A180 & $\begin{array}{l}\text { Agravo em } \\
\text { Execução }\end{array}$ & $990.10 .270230-8$ & Roberto Mortari & $\begin{array}{c}8^{\mathrm{a}} \\
\text { Câmara } \\
\text { Criminal }\end{array}$ & $14 / 10 / 2010$ \\
\hline A181 & $\begin{array}{l}\text { Agravo em } \\
\text { Execução }\end{array}$ & $\begin{array}{c}0040112- \\
31.2011 .8 .26 .0000\end{array}$ & Roberto Mortari & $\begin{array}{c}8^{\mathrm{a}} \\
\text { Câmara } \\
\text { Criminal }\end{array}$ & 09/06/2011 \\
\hline A182 & $\begin{array}{l}\text { Agravo em } \\
\text { Execução }\end{array}$ & $\begin{array}{c}0059820- \\
67.2011 .8 .26 .0000\end{array}$ & Sérgio Coelho & $\begin{array}{c}8^{\mathrm{a}} \\
\text { Câmara } \\
\text { Criminal }\end{array}$ & $28 / 07 / 2011$ \\
\hline A183 & $\begin{array}{l}\text { Agravo em } \\
\text { Execução }\end{array}$ & $\begin{array}{c}0043060- \\
43.2011 .8 .26 .0000\end{array}$ & Zorzi Rocha & $\begin{array}{c}8^{\mathrm{a}} \\
\text { Câmara } \\
\text { Criminal }\end{array}$ & $20 / 10 / 2011$ \\
\hline A184 & $\begin{array}{l}\text { Agravo em } \\
\text { Execução }\end{array}$ & $\begin{array}{c}0080361- \\
24.2011 .8 .26 .0000\end{array}$ & Moreira da Silva & $\begin{array}{c}8^{\mathrm{a}} \\
\text { Câmara } \\
\text { Criminal }\end{array}$ & $15 / 09 / 2011$ \\
\hline A185 & $\begin{array}{l}\text { Agravo em } \\
\text { Execução }\end{array}$ & $\begin{array}{c}0122798- \\
80.2011 .8 .26 .0000\end{array}$ & $\begin{array}{c}\text { Marco Antônio } \\
\text { Cogan }\end{array}$ & $\begin{array}{c}8^{\mathrm{a}} \\
\text { Câmara } \\
\text { Criminal }\end{array}$ & $24 / 11 / 2011$ \\
\hline A186 & Agravo em & $0078527-$ & Amado de Faria & $8^{a}$ & $04 / 10 / 2012$ \\
\hline
\end{tabular}




\begin{tabular}{|c|c|c|c|c|c|}
\hline & Execução & 49.2012.8.26.0000 & & $\begin{array}{l}\text { Câmara } \\
\text { Criminal }\end{array}$ & \\
\hline A187 & $\begin{array}{l}\text { Agravo em } \\
\text { Execução }\end{array}$ & $\begin{array}{c}\text { 0020747- } \\
54.2012 .8 .26 .0000\end{array}$ & Zorzi Rocha & $\begin{array}{c}8^{\mathrm{a}} \\
\text { Câmara } \\
\text { Criminal }\end{array}$ & 05/07/2012 \\
\hline A188 & $\begin{array}{l}\text { Agravo em } \\
\text { Execução }\end{array}$ & $\begin{array}{c}0154736- \\
59.2012 .8 .26 .0000\end{array}$ & Moreira da Silva & $\begin{array}{c}8^{\mathrm{a}} \\
\text { Câmara } \\
\text { Criminal }\end{array}$ & $18 / 10 / 2012$ \\
\hline A189 & $\begin{array}{l}\text { Agravo em } \\
\text { Execução }\end{array}$ & $\begin{array}{c}0211648- \\
76.2012 .8 .26 .0000\end{array}$ & $\begin{array}{c}\text { Marco Antônio } \\
\text { Cogan }\end{array}$ & $\begin{array}{c}8^{\mathrm{a}} \\
\text { Câmara } \\
\text { Criminal }\end{array}$ & $06 / 12 / 2012$ \\
\hline A190 & $\begin{array}{l}\text { Agravo em } \\
\text { Execução }\end{array}$ & $\begin{array}{c}\text { 0215075- } \\
81.2012 .8 .26 .0000\end{array}$ & Camilo Léllis & $\begin{array}{c}8^{\mathrm{a}} \\
\text { Câmara } \\
\text { Criminal }\end{array}$ & $06 / 12 / 2012$ \\
\hline A191 & $\begin{array}{l}\text { Agravo em } \\
\text { Execução }\end{array}$ & $\begin{array}{c}0101894- \\
05.2012 .8 .26 .0000\end{array}$ & Zorzi Rocha & $\begin{array}{c}8^{\mathrm{a}} \\
\text { Câmara } \\
\text { Criminal }\end{array}$ & $04 / 04 / 2013$ \\
\hline A192 & $\begin{array}{l}\text { Agravo em } \\
\text { Execução }\end{array}$ & $\begin{array}{c}0170373- \\
16.2013 .8 .26 .0000\end{array}$ & Camilo Léllis & $\begin{array}{c}8^{\mathrm{a}} \\
\text { Câmara } \\
\text { Criminal }\end{array}$ & $07 / 11 / 2013$ \\
\hline A193 & $\begin{array}{l}\text { Agravo em } \\
\text { Execução }\end{array}$ & $\begin{array}{c}0141373- \\
68.2013 .8 .26 .0000\end{array}$ & Ivo de Almeida & $\begin{array}{c}8^{\mathrm{a}} \\
\text { Câmara } \\
\text { Criminal }\end{array}$ & $14 / 11 / 2013$ \\
\hline A194 & $\begin{array}{l}\text { Agravo em } \\
\text { Execução }\end{array}$ & $\begin{array}{c}0170202- \\
59.2013 .8 .26 .0000\end{array}$ & $\begin{array}{l}\text { Marco Antônio } \\
\text { Cogan }\end{array}$ & $\begin{array}{c}8^{\mathrm{a}} \\
\text { Câmara } \\
\text { Criminal }\end{array}$ & $21 / 11 / 2013$ \\
\hline A195 & $\begin{array}{l}\text { Agravo em } \\
\text { Execução }\end{array}$ & $\begin{array}{c}0174296- \\
50.2013 .8 .26 .0000\end{array}$ & Moreira da Silva & $\begin{array}{c}8^{\mathrm{a}} \\
\text { Câmara } \\
\text { Criminal }\end{array}$ & $21 / 11 / 2013$ \\
\hline A196 & $\begin{array}{l}\text { Agravo em } \\
\text { Execução }\end{array}$ & $\begin{array}{c}0039464- \\
46.2014 .8 .26 .0000\end{array}$ & Moreira da Silva & $\begin{array}{c}8^{\mathrm{a}} \\
\text { Câmara } \\
\text { Criminal }\end{array}$ & $28 / 08 / 2014$ \\
\hline A197 & Agravo em & $0053612-$ & Marco Antônio & $8^{a}$ & $25 / 09 / 2014$ \\
\hline
\end{tabular}




\begin{tabular}{|c|c|c|c|c|c|}
\hline & Execução & 62.2014 .8 .26 .0000 & Cogan & $\begin{array}{l}\text { Câmara } \\
\text { Criminal }\end{array}$ & \\
\hline A198 & $\begin{array}{l}\text { Agravo em } \\
\text { Execução }\end{array}$ & $\begin{array}{c}7001853- \\
46.2013 .8 .26 .0073\end{array}$ & Louri Barbiero & $\begin{array}{c}8^{\mathrm{a}} \\
\text { Câmara } \\
\text { Criminal }\end{array}$ & $16 / 10 / 2014$ \\
\hline A199 & $\begin{array}{l}\text { Agravo em } \\
\text { Execução }\end{array}$ & $\begin{array}{c}0053517- \\
32.2014 .8 .26 .0000\end{array}$ & $\begin{array}{c}\text { Alcides Malossi } \\
\text { Junior }\end{array}$ & $\begin{array}{c}8^{\mathrm{a}} \\
\text { Câmara } \\
\text { Criminal }\end{array}$ & $18 / 12 / 2014$ \\
\hline A 200 & $\begin{array}{l}\text { Agravo em } \\
\text { Execução }\end{array}$ & $\begin{array}{c}\text { 0036707- } \\
79.2014 .8 .26 .0000\end{array}$ & Grassi Neto & $\begin{array}{c}8^{\mathrm{a}} \\
\text { Câmara } \\
\text { Criminal }\end{array}$ & $18 / 12 / 2014$ \\
\hline A201 & $\begin{array}{l}\text { Agravo em } \\
\text { Execução }\end{array}$ & $990.09 .325239-2$ & Roberto Midolla & $\begin{array}{c}9^{\mathrm{a}} \\
\text { Câmara } \\
\text { Criminal }\end{array}$ & $08 / 04 / 2010$ \\
\hline A202 & $\begin{array}{l}\text { Agravo em } \\
\text { Execução }\end{array}$ & 990.09.201108-1 & Sérgio Coelho & $\begin{array}{c}9^{\mathrm{a}} \\
\text { Câmara } \\
\text { Criminal }\end{array}$ & $28 / 01 / 2010$ \\
\hline A203 & $\begin{array}{l}\text { Agravo em } \\
\text { Execução }\end{array}$ & $990.10 .298574-1$ & Francisco Bruno & $\begin{array}{c}9^{\mathrm{a}} \\
\text { Câmara } \\
\text { Criminal }\end{array}$ & $16 / 09 / 2010$ \\
\hline A204 & $\begin{array}{l}\text { Agravo em } \\
\text { Execução }\end{array}$ & $990.10 .283553-7$ & Roberto Midolla & $\begin{array}{c}9^{\mathrm{a}} \\
\text { Câmara } \\
\text { Criminal }\end{array}$ & $18 / 11 / 2010$ \\
\hline A205 & $\begin{array}{l}\text { Agravo em } \\
\text { Execução }\end{array}$ & $990.10 .363789-5$ & Souza Nery & $\begin{array}{c}9^{\mathrm{a}} \\
\text { Câmara } \\
\text { Criminal }\end{array}$ & $09 / 12 / 2010$ \\
\hline A206 & $\begin{array}{l}\text { Agravo em } \\
\text { Execução }\end{array}$ & $\begin{array}{c}0152277- \\
21.2011 .8 .26 .0000\end{array}$ & Souza Nery & $\begin{array}{c}9^{\mathrm{a}} \\
\text { Câmara } \\
\text { Criminal }\end{array}$ & $10 / 11 / 2011$ \\
\hline A207 & $\begin{array}{l}\text { Agravo em } \\
\text { Execução }\end{array}$ & $\begin{array}{c}0173278- \\
62.2011 .8 .26 .0000\end{array}$ & Roberto Midolla & $\begin{array}{c}9^{\mathrm{a}} \\
\text { Câmara } \\
\text { Criminal }\end{array}$ & $15 / 12 / 2011$ \\
\hline A208 & Agravo em & $0105133-$ & Julio Caio Farto & $9^{a}$ & $15 / 12 / 2011$ \\
\hline
\end{tabular}




\begin{tabular}{|c|c|c|c|c|c|}
\hline & Execução & 51.2011.8.26.0000 & Salles & $\begin{array}{l}\text { Câmara } \\
\text { Criminal }\end{array}$ & \\
\hline A209 & $\begin{array}{l}\text { Agravo em } \\
\text { Execução }\end{array}$ & $\begin{array}{c}0154964- \\
68.2011 .8 .26 .0000\end{array}$ & Otávio Henrique & $\begin{array}{c}9^{\mathrm{a}} \\
\text { Câmara } \\
\text { Criminal }\end{array}$ & $15 / 12 / 2011$ \\
\hline A210 & $\begin{array}{l}\text { Agravo em } \\
\text { Execução }\end{array}$ & $\begin{array}{c}0189946- \\
11.2011 .8 .26 .0000\end{array}$ & Francisco Bruno & $\begin{array}{c}9^{\mathrm{a}} \\
\text { Câmara } \\
\text { Criminal }\end{array}$ & $15 / 12 / 2011$ \\
\hline A 211 & $\begin{array}{l}\text { Agravo em } \\
\text { Execução }\end{array}$ & $\begin{array}{c}0047024- \\
10.2012 .8 .26 .0000\end{array}$ & Sérgio Coelho & $\begin{array}{c}9^{\mathrm{a}} \\
\text { Câmara } \\
\text { Criminal }\end{array}$ & 09/08/2012 \\
\hline A212 & $\begin{array}{l}\text { Agravo em } \\
\text { Execução }\end{array}$ & $\begin{array}{c}0058974- \\
16.2012 .8 .26 .0000\end{array}$ & $\begin{array}{c}\text { Julio Caio Farto } \\
\text { Salles }\end{array}$ & $\begin{array}{c}9^{\mathrm{a}} \\
\text { Câmara } \\
\text { Criminal }\end{array}$ & 09/08/2012 \\
\hline A213 & $\begin{array}{l}\text { Agravo em } \\
\text { Execução }\end{array}$ & $\begin{array}{c}\text { 0163060- } \\
38.2012 .8 .26 .0000\end{array}$ & Otávio Henrique & $\begin{array}{c}9^{\mathrm{a}} \\
\text { Câmara } \\
\text { Criminal }\end{array}$ & $08 / 11 / 2012$ \\
\hline A214 & $\begin{array}{l}\text { Agravo em } \\
\text { Execução }\end{array}$ & $\begin{array}{c}0158291- \\
84.2012 .8 .26 .0000\end{array}$ & Roberto Midolla & $\begin{array}{c}9^{\mathrm{a}} \\
\text { Câmara } \\
\text { Criminal }\end{array}$ & $29 / 11 / 2012$ \\
\hline A215 & $\begin{array}{l}\text { Agravo em } \\
\text { Execução }\end{array}$ & $\begin{array}{c}0225673- \\
94.2012 .8 .26 .0000\end{array}$ & Souza Nery & $\begin{array}{c}9^{\mathrm{a}} \\
\text { Câmara } \\
\text { Criminal }\end{array}$ & $13 / 12 / 2012$ \\
\hline A216 & $\begin{array}{l}\text { Agravo em } \\
\text { Execução }\end{array}$ & $\begin{array}{c}0108362- \\
48.2013 .8 .26 .0000\end{array}$ & Penteado Navarro & $\begin{array}{c}9^{\mathrm{a}} \\
\text { Câmara } \\
\text { Criminal }\end{array}$ & $22 / 08 / 2013$ \\
\hline A217 & $\begin{array}{l}\text { Agravo em } \\
\text { Execução }\end{array}$ & $\begin{array}{c}0129245- \\
16.2013 .8 .26 .0000\end{array}$ & Otávio Henrique & $\begin{array}{c}9^{\mathrm{a}} \\
\text { Câmara } \\
\text { Criminal }\end{array}$ & $10 / 10 / 2013$ \\
\hline A218 & $\begin{array}{l}\text { Agravo em } \\
\text { Execução }\end{array}$ & $\begin{array}{c}\text { 0179781- } \\
31.2013 .8 .26 .0000\end{array}$ & Roberto Midolla & $\begin{array}{c}9^{\mathrm{a}} \\
\text { Câmara } \\
\text { Criminal }\end{array}$ & $21 / 11 / 2013$ \\
\hline A219 & Agravo em & 0175139- & Roberto Midolla & $9^{a}$ & $07 / 11 / 2013$ \\
\hline
\end{tabular}




\begin{tabular}{|c|c|c|c|c|c|}
\hline & Execução & 15.2013 .8 .26 .0000 & & $\begin{array}{l}\text { Câmara } \\
\text { Criminal }\end{array}$ & \\
\hline A220 & $\begin{array}{l}\text { Agravo em } \\
\text { Execução }\end{array}$ & $\begin{array}{c}0156793- \\
16.2013 .8 .26 .0000\end{array}$ & Souza Nery & $\begin{array}{c}9^{\mathrm{a}} \\
\text { Câmara } \\
\text { Criminal }\end{array}$ & $12 / 12 / 2013$ \\
\hline A221 & $\begin{array}{l}\text { Agravo em } \\
\text { Execução }\end{array}$ & $\begin{array}{c}0051111- \\
38.2014 .8 .26 .0000\end{array}$ & Sérgio Coelho & $\begin{array}{c}9^{\mathrm{a}} \\
\text { Câmara } \\
\text { Criminal }\end{array}$ & $13 / 11 / 2014$ \\
\hline A222 & $\begin{array}{l}\text { Agravo em } \\
\text { Execução }\end{array}$ & $\begin{array}{c}0068032- \\
72.2014 .8 .26 .0000\end{array}$ & Roberto Solimene & $\begin{array}{c}9^{\mathrm{a}} \\
\text { Câmara } \\
\text { Criminal }\end{array}$ & $27 / 11 / 2014$ \\
\hline A223 & $\begin{array}{l}\text { Agravo em } \\
\text { Execução }\end{array}$ & $\begin{array}{c}\text { 0047397- } \\
70.2014 .8 .26 .0000\end{array}$ & Otávio Henrique & $\begin{array}{c}9^{\mathrm{a}} \\
\text { Câmara } \\
\text { Criminal }\end{array}$ & $27 / 11 / 2014$ \\
\hline A224 & $\begin{array}{l}\text { Agravo em } \\
\text { Execução }\end{array}$ & $\begin{array}{c}7018496- \\
16.2013 .8 .26 .0482\end{array}$ & Roberto Midolla & $\begin{array}{c}9^{\mathrm{a}} \\
\text { Câmara } \\
\text { Criminal }\end{array}$ & $04 / 12 / 2014$ \\
\hline A225 & $\begin{array}{l}\text { Agravo em } \\
\text { Execução }\end{array}$ & $\begin{array}{c}\text { 0053176- } \\
06.2014 .8 .26 .0000\end{array}$ & Souza Nery & $\begin{array}{c}9^{\mathrm{a}} \\
\text { Câmara } \\
\text { Criminal }\end{array}$ & $27 / 11 / 2014$ \\
\hline A226 & $\begin{array}{l}\text { Agravo em } \\
\text { Execução }\end{array}$ & $990.09 .203415-4$ & Otávio Henrique & $\begin{array}{c}10^{\mathrm{a}} \\
\text { Câmara } \\
\text { Criminal }\end{array}$ & $14 / 01 / 2010$ \\
\hline A227 & $\begin{array}{l}\text { Agravo em } \\
\text { Execução }\end{array}$ & $990.09 .212898-1$ & Fábio Gouvêa & $\begin{array}{c}10^{\mathrm{a}} \\
\text { Câmara } \\
\text { Criminal }\end{array}$ & $10 / 06 / 2010$ \\
\hline A228 & $\begin{array}{l}\text { Agravo em } \\
\text { Execução }\end{array}$ & $990.09 .212898-1$ & Fábio Gouvêa & $\begin{array}{c}10^{\mathrm{a}} \\
\text { Câmara } \\
\text { Criminal }\end{array}$ & $10 / 06 / 2010$ \\
\hline A229 & $\begin{array}{l}\text { Agravo em } \\
\text { Execução }\end{array}$ & $990.10 .337708-7$ & Carlos Bueno & $\begin{array}{c}10^{\mathrm{a}} \\
\text { Câmara } \\
\text { Criminal }\end{array}$ & $11 / 11 / 2010$ \\
\hline A230 & Agravo em & $990.10 .365601-6$ & Otávio Henrique & $10^{\mathrm{a}}$ & $02 / 12 / 2010$ \\
\hline
\end{tabular}




\begin{tabular}{|c|c|c|c|c|c|}
\hline & Execução & & & $\begin{array}{l}\text { Câmara } \\
\text { Criminal }\end{array}$ & \\
\hline A231 & $\begin{array}{l}\text { Agravo em } \\
\text { Execução }\end{array}$ & $\begin{array}{l}9184854-64.2 \\
009.8 .26 .0000\end{array}$ & David Haddad & $\begin{array}{c}10^{\mathrm{a}} \\
\text { Câmara } \\
\text { Criminal }\end{array}$ & 01/09/2011 \\
\hline A232 & $\begin{array}{l}\text { Agravo em } \\
\text { Execução }\end{array}$ & $\begin{array}{c}0357759- \\
97.2010 .8 .26 .0000\end{array}$ & Otávio Henrique & $\begin{array}{c}10^{\mathrm{a}} \\
\text { Câmara } \\
\text { Criminal }\end{array}$ & $13 / 01 / 2011$ \\
\hline A233 & $\begin{array}{l}\text { Agravo em } \\
\text { Execução }\end{array}$ & $\begin{array}{c}0499481- \\
22.2010 .8 .26 .0000\end{array}$ & Otávio Henrique & $\begin{array}{c}10^{\mathrm{a}} \\
\text { Câmara } \\
\text { Criminal }\end{array}$ & $24 / 02 / 2011$ \\
\hline A234 & $\begin{array}{l}\text { Agravo em } \\
\text { Execução }\end{array}$ & $\begin{array}{c}\text { 0085909- } \\
30.2011 .8 .26 .0000\end{array}$ & Mauricio Valala & $\begin{array}{c}10^{\mathrm{a}} \\
\text { Câmara } \\
\text { Criminal }\end{array}$ & 20/10/2011 \\
\hline A235 & $\begin{array}{l}\text { Agravo em } \\
\text { Execução }\end{array}$ & $\begin{array}{c}0210042- \\
47.2011 .8 .26 .0000\end{array}$ & Fábio Gouvêa & $\begin{array}{c}10^{\mathrm{a}} \\
\text { Câmara } \\
\text { Criminal }\end{array}$ & $15 / 12 / 2011$ \\
\hline A236 & $\begin{array}{l}\text { Agravo em } \\
\text { Execução }\end{array}$ & $\begin{array}{c}0096791- \\
17.2012 .8 .26 .0000\end{array}$ & Francisco Bruno & $\begin{array}{c}10^{\mathrm{a}} \\
\text { Câmara } \\
\text { Criminal }\end{array}$ & $13 / 09 / 2012$ \\
\hline A237 & $\begin{array}{l}\text { Agravo em } \\
\text { Execução }\end{array}$ & $\begin{array}{c}0095788- \\
27.2012 .8 .26 .0000\end{array}$ & Fábio Gouvêa & $\begin{array}{c}10^{\mathrm{a}} \\
\text { Câmara } \\
\text { Criminal }\end{array}$ & $13 / 09 / 2012$ \\
\hline A238 & $\begin{array}{l}\text { Agravo em } \\
\text { Execução }\end{array}$ & $\begin{array}{c}0096342- \\
59.2012 .8 .26 .0000\end{array}$ & Francisco Bruno & $\begin{array}{c}10^{\mathrm{a}} \\
\text { Câmara } \\
\text { Criminal }\end{array}$ & $08 / 11 / 2012$ \\
\hline A239 & $\begin{array}{l}\text { Agravo em } \\
\text { Execução }\end{array}$ & $\begin{array}{c}0176090- \\
43.2012 .8 .26 .0000\end{array}$ & Francisco Bruno & $\begin{array}{c}10^{\mathrm{a}} \\
\text { Câmara } \\
\text { Criminal }\end{array}$ & $08 / 11 / 2012$ \\
\hline A240 & $\begin{array}{l}\text { Agravo em } \\
\text { Execução }\end{array}$ & $\begin{array}{c}\text { 0207065- } \\
48.2012 .8 .26 .0000\end{array}$ & Fábio Gouvêa & $\begin{array}{c}10^{\mathrm{a}} \\
\text { Câmara } \\
\text { Criminal }\end{array}$ & $13 / 12 / 2012$ \\
\hline A241 & Agravo em & 0233100- & Nelson Fonseca & $10^{\mathrm{a}}$ & $31 / 01 / 2013$ \\
\hline
\end{tabular}




\begin{tabular}{|c|c|c|c|c|c|}
\hline & Execução & 45.2012 .8 .26 .0000 & Junior & $\begin{array}{l}\text { Câmara } \\
\text { Criminal }\end{array}$ & \\
\hline A242 & $\begin{array}{l}\text { Agravo em } \\
\text { Execução }\end{array}$ & $\begin{array}{c}0053961- \\
70.2011 .8 .26 .0000\end{array}$ & $\begin{array}{c}\text { Rachid Vaz de } \\
\text { Almeida }\end{array}$ & $\begin{array}{c}10^{\mathrm{a}} \\
\text { Câmara } \\
\text { Criminal }\end{array}$ & $29 / 08 / 2013$ \\
\hline A243 & $\begin{array}{l}\text { Agravo em } \\
\text { Execução }\end{array}$ & $\begin{array}{c}0131761- \\
09.2013 .8 .26 .0000\end{array}$ & Carlos Bueno & $\begin{array}{c}10^{\mathrm{a}} \\
\text { Câmara } \\
\text { Criminal }\end{array}$ & $29 / 08 / 2013$ \\
\hline A244 & $\begin{array}{l}\text { Agravo em } \\
\text { Execução }\end{array}$ & $\begin{array}{c}\text { 0157589- } \\
07.2013 .8 .26 .0000\end{array}$ & Francisco Bruno & $\begin{array}{c}10^{\mathrm{a}} \\
\text { Câmara } \\
\text { Criminal }\end{array}$ & $07 / 11 / 2013$ \\
\hline A245 & $\begin{array}{l}\text { Agravo em } \\
\text { Execução }\end{array}$ & $\begin{array}{c}\text { 0175406- } \\
84.2013 .8 .26 .0000\end{array}$ & Fábio Gouvêa & $\begin{array}{c}10^{\mathrm{a}} \\
\text { Câmara } \\
\text { Criminal }\end{array}$ & $21 / 11 / 2013$ \\
\hline A246 & $\begin{array}{l}\text { Agravo em } \\
\text { Execução }\end{array}$ & $\begin{array}{c}\text { 7012726- } \\
\text { 42.2013.8.26.0482 }\end{array}$ & Fábio Gouvêa & $\begin{array}{c}10^{\mathrm{a}} \\
\text { Câmara } \\
\text { Criminal }\end{array}$ & $26 / 05 / 2014$ \\
\hline A247 & $\begin{array}{l}\text { Agravo em } \\
\text { Execução }\end{array}$ & $\begin{array}{c}0030366- \\
37.2014 .8 .26 .0000\end{array}$ & $\begin{array}{c}\text { Rachid Vaz de } \\
\text { Almeida }\end{array}$ & $\begin{array}{c}10^{\mathrm{a}} \\
\text { Câmara } \\
\text { Criminal }\end{array}$ & $11 / 08 / 2014$ \\
\hline A248 & $\begin{array}{l}\text { Agravo em } \\
\text { Execução }\end{array}$ & $\begin{array}{c}\text { 7000659- } \\
65.2013 .8 .26 .0637\end{array}$ & Carlos Bueno & $\begin{array}{c}10^{\mathrm{a}} \\
\text { Câmara } \\
\text { Criminal }\end{array}$ & $11 / 09 / 2014$ \\
\hline A249 & $\begin{array}{l}\text { Agravo em } \\
\text { Execução }\end{array}$ & $\begin{array}{c}\text { 7013484- } \\
21.2013 .8 .26 .0482\end{array}$ & Francisco Bruno & $\begin{array}{c}10^{\mathrm{a}} \\
\text { Câmara } \\
\text { Criminal }\end{array}$ & $06 / 11 / 2014$ \\
\hline A 250 & $\begin{array}{l}\text { Agravo em } \\
\text { Execução }\end{array}$ & $\begin{array}{c}7004428- \\
36.2014 .8 .26 .0576\end{array}$ & Fábio Gouvêa & $\begin{array}{c}10^{\mathrm{a}} \\
\text { Câmara } \\
\text { Criminal }\end{array}$ & $11 / 12 / 2014$ \\
\hline A251 & $\begin{array}{l}\text { Agravo em } \\
\text { Execução }\end{array}$ & $990.10 .102082-3$ & $\begin{array}{c}\text { Rachid Vaz de } \\
\text { Almeida }\end{array}$ & $\begin{array}{c}11^{\mathrm{a}} \\
\text { Câmara } \\
\text { Criminal }\end{array}$ & $04 / 08 / 2010$ \\
\hline A252 & Agravo em & 990.10.167954-0 & Oliveira Passos & $11^{\mathrm{a}}$ & $25 / 08 / 2010$ \\
\hline
\end{tabular}




\begin{tabular}{|c|c|c|c|c|c|}
\hline & Execução & & & $\begin{array}{l}\text { Câmara } \\
\text { Criminal }\end{array}$ & \\
\hline A253 & $\begin{array}{l}\text { Agravo em } \\
\text { Execução }\end{array}$ & $990.10 .278616-1$ & $\begin{array}{c}\text { Maria Tereza do } \\
\text { Amaral }\end{array}$ & $\begin{array}{c}11^{\mathrm{a}} \\
\text { Câmara } \\
\text { Criminal }\end{array}$ & $17 / 11 / 2010$ \\
\hline A254 & $\begin{array}{l}\text { Agravo em } \\
\text { Execução }\end{array}$ & $990.10 .376707-1$ & $\begin{array}{c}\text { Guilherme G. } \\
\text { Strenger }\end{array}$ & $\begin{array}{c}11^{\mathrm{a}} \\
\text { Câmara } \\
\text { Criminal }\end{array}$ & $15 / 12 / 2010$ \\
\hline A255 & $\begin{array}{l}\text { Agravo em } \\
\text { Execução }\end{array}$ & $990.10 .330698-8$ & Antonio Manssur & $\begin{array}{c}11^{\mathrm{a}} \\
\text { Câmara } \\
\text { Criminal }\end{array}$ & $15 / 12 / 2010$ \\
\hline A256 & $\begin{array}{l}\text { Agravo em } \\
\text { Execução }\end{array}$ & $\begin{array}{c}0076415- \\
44.2011 .8 .26 .0000\end{array}$ & Xavier de Souza & $\begin{array}{c}11^{\mathrm{a}} \\
\text { Câmara } \\
\text { Criminal }\end{array}$ & $19 / 10 / 2011$ \\
\hline A 257 & $\begin{array}{l}\text { Agravo em } \\
\text { Execução }\end{array}$ & $\begin{array}{c}0062020- \\
47.2011 .8 .26 .0000\end{array}$ & $\begin{array}{c}\text { Maria Tereza do } \\
\text { Amaral }\end{array}$ & $\begin{array}{c}11^{\mathrm{a}} \\
\text { Câmara } \\
\text { Criminal }\end{array}$ & 05/10/2011 \\
\hline A258 & $\begin{array}{l}\text { Agravo em } \\
\text { Execução }\end{array}$ & $\begin{array}{c}0100785- \\
87.2011 .8 .26 .0000\end{array}$ & Antonio Manssur & $\begin{array}{c}11^{\mathrm{a}} \\
\text { Câmara } \\
\text { Criminal }\end{array}$ & $23 / 11 / 2011$ \\
\hline A259 & $\begin{array}{l}\text { Agravo em } \\
\text { Execução }\end{array}$ & $\begin{array}{c}0081347- \\
75.2011 .8 .26 .0000\end{array}$ & $\begin{array}{c}\text { Aben-Athar } \\
\text { (Paiva Coutinho) }\end{array}$ & $\begin{array}{c}11^{\mathrm{a}} \\
\text { Câmara } \\
\text { Criminal }\end{array}$ & $30 / 11 / 2011$ \\
\hline A260 & $\begin{array}{l}\text { Agravo em } \\
\text { Execução }\end{array}$ & $\begin{array}{c}0160838- \\
34.2011 .8 .26 .0000\end{array}$ & $\begin{array}{c}\text { Guilherme G. } \\
\text { Strenger }\end{array}$ & $\begin{array}{c}11^{\mathrm{a}} \\
\text { Câmara } \\
\text { Criminal }\end{array}$ & $23 / 11 / 2011$ \\
\hline A261 & $\begin{array}{l}\text { Agravo em } \\
\text { Execução }\end{array}$ & $\begin{array}{c}\text { 0075106- } \\
51.2012 .8 .26 .0000\end{array}$ & $\begin{array}{c}\text { Maria Tereza do } \\
\text { Amaral }\end{array}$ & $\begin{array}{c}11^{\mathrm{a}} \\
\text { Câmara } \\
\text { Criminal }\end{array}$ & 03/10/2012 \\
\hline A262 & $\begin{array}{l}\text { Agravo em } \\
\text { Execução }\end{array}$ & $\begin{array}{c}0167774- \\
41.2012 .8 .26 .0000\end{array}$ & Antonio Manssur & $\begin{array}{c}11^{\mathrm{a}} \\
\text { Câmara } \\
\text { Criminal }\end{array}$ & $07 / 11 / 2012$ \\
\hline A263 & Agravo em & $0121343-$ & Xavier de Souza & $11^{\mathrm{a}}$ & $14 / 11 / 2012$ \\
\hline
\end{tabular}




\begin{tabular}{|c|c|c|c|c|c|}
\hline & Execução & 46.2012 .8 .26 .0000 & & $\begin{array}{l}\text { Câmara } \\
\text { Criminal }\end{array}$ & \\
\hline A264 & $\begin{array}{l}\text { Agravo em } \\
\text { Execução }\end{array}$ & $\begin{array}{c}0203611- \\
60.2012 .8 .26 .0000\end{array}$ & $\begin{array}{c}\text { Guilherme G. } \\
\text { Strenger }\end{array}$ & $\begin{array}{c}11^{\mathrm{a}} \\
\text { Câmara } \\
\text { Criminal }\end{array}$ & $14 / 11 / 2012$ \\
\hline A265 & $\begin{array}{l}\text { Agravo em } \\
\text { Execução }\end{array}$ & $\begin{array}{c}0093185- \\
78.2012 .8 .26 .0000\end{array}$ & Paiva Coutinho & $\begin{array}{c}11^{\mathrm{a}} \\
\text { Câmara } \\
\text { Criminal }\end{array}$ & $05 / 12 / 2012$ \\
\hline A266 & $\begin{array}{l}\text { Agravo em } \\
\text { Execução }\end{array}$ & $\begin{array}{c}0132797- \\
86.2013 .8 .26 .0000\end{array}$ & $\begin{array}{c}\text { Maria Tereza do } \\
\text { Amaral }\end{array}$ & $\begin{array}{c}11^{\mathrm{a}} \\
\text { Câmara } \\
\text { Criminal }\end{array}$ & $16 / 10 / 2013$ \\
\hline A267 & $\begin{array}{l}\text { Agravo em } \\
\text { Execução }\end{array}$ & $\begin{array}{c}0146206- \\
32.2013 .8 .26 .0000\end{array}$ & Xavier de Souza & $\begin{array}{c}11^{\mathrm{a}} \\
\text { Câmara } \\
\text { Criminal }\end{array}$ & $30 / 10 / 2013$ \\
\hline A268 & $\begin{array}{l}\text { Agravo em } \\
\text { Execução }\end{array}$ & $\begin{array}{c}0147328- \\
80.2013 .8 .26 .0000\end{array}$ & Paiva Coutinho & $\begin{array}{c}11^{\mathrm{a}} \\
\text { Câmara } \\
\text { Criminal }\end{array}$ & $13 / 11 / 2013$ \\
\hline A269 & $\begin{array}{l}\text { Agravo em } \\
\text { Execução }\end{array}$ & $\begin{array}{c}0184085- \\
73.2013 .8 .26 .0000\end{array}$ & $\begin{array}{c}\text { Guilherme G. } \\
\text { Strenger }\end{array}$ & $\begin{array}{c}1^{11^{\mathrm{a}}} \\
\text { Câmara } \\
\text { Criminal }\end{array}$ & $27 / 11 / 2013$ \\
\hline A270 & $\begin{array}{l}\text { Agravo em } \\
\text { Execução }\end{array}$ & $\begin{array}{c}0188111- \\
17.2013 .8 .26 .0000\end{array}$ & Salles Abreu & $\begin{array}{c}11^{\mathrm{a}} \\
\text { Câmara } \\
\text { Criminal }\end{array}$ & $16 / 12 / 2013$ \\
\hline A271 & $\begin{array}{l}\text { Agravo em } \\
\text { Execução }\end{array}$ & $\begin{array}{c}0196426- \\
34.2013 .8 .26 .0000\end{array}$ & $\begin{array}{c}\text { Maria Tereza do } \\
\text { Amaral }\end{array}$ & $\begin{array}{c}11^{\mathrm{a}} \\
\text { Câmara } \\
\text { Criminal }\end{array}$ & $29 / 10 / 2014$ \\
\hline A 272 & $\begin{array}{l}\text { Agravo em } \\
\text { Execução }\end{array}$ & $\begin{array}{c}0054006- \\
69.2014 .8 .26 .0000\end{array}$ & $\begin{array}{c}\text { Guilherme G. } \\
\text { Strenger }\end{array}$ & $\begin{array}{c}11^{\mathrm{a}} \\
\text { Câmara } \\
\text { Criminal }\end{array}$ & $19 / 11 / 2014$ \\
\hline A273 & $\begin{array}{l}\text { Agravo em } \\
\text { Execução }\end{array}$ & $\begin{array}{c}0038721- \\
36.2014 .8 .26 .0000\end{array}$ & Paiva Coutinho & $\begin{array}{c}11^{\mathrm{a}} \\
\text { Câmara } \\
\text { Criminal }\end{array}$ & $03 / 12 / 2014$ \\
\hline A274 & Agravo em & 7000666- & Xavier de Souza & $11^{\mathrm{a}}$ & $03 / 12 / 2014$ \\
\hline
\end{tabular}




\begin{tabular}{|c|c|c|c|c|c|}
\hline & Execução & 66.2014.8.26.0073 & & $\begin{array}{l}\text { Câmara } \\
\text { Criminal }\end{array}$ & \\
\hline A 275 & $\begin{array}{l}\text { Agravo em } \\
\text { Execução }\end{array}$ & $\begin{array}{c}\text { 7001371- } \\
\text { 77.2014.8.26.0198 }\end{array}$ & Salles Abreu & $\begin{array}{c}11^{\mathrm{a}} \\
\text { Câmara } \\
\text { Criminal }\end{array}$ & $10 / 12 / 2014$ \\
\hline A276 & $\begin{array}{l}\text { Agravo em } \\
\text { Execução }\end{array}$ & $990.09 .224897-9$ & Vico Mañas & $\begin{array}{c}12^{\mathrm{a}} \\
\text { Câmara } \\
\text { Criminal }\end{array}$ & $03 / 02 / 2010$ \\
\hline A277 & $\begin{array}{l}\text { Agravo em } \\
\text { Execução }\end{array}$ & $990.09 .183816-0$ & João Morenghi & $\begin{array}{c}12^{\mathrm{a}} \\
\text { Câmara } \\
\text { Criminal }\end{array}$ & $24 / 03 / 2010$ \\
\hline A278 & $\begin{array}{l}\text { Agravo em } \\
\text { Execução }\end{array}$ & $990.10 .142858-0$ & Paulo Rossi & $\begin{array}{c}12^{\mathrm{a}} \\
\text { Câmara } \\
\text { Criminal }\end{array}$ & $04 / 08 / 2010$ \\
\hline A279 & $\begin{array}{l}\text { Agravo em } \\
\text { Execução }\end{array}$ & $990.10 .271753-4$ & Vico Mañas & $\begin{array}{c}12^{\mathrm{a}} \\
\text { Câmara } \\
\text { Criminal }\end{array}$ & $06 / 10 / 2010$ \\
\hline A280 & $\begin{array}{l}\text { Agravo em } \\
\text { Execução }\end{array}$ & $990.10 .277771-5$ & João Morenghi & $\begin{array}{c}12^{\mathrm{a}} \\
\text { Câmara } \\
\text { Criminal }\end{array}$ & $15 / 12 / 2010$ \\
\hline A281 & $\begin{array}{l}\text { Agravo em } \\
\text { Execução }\end{array}$ & $\begin{array}{c}0375583- \\
69.2010 .8 .26 .0000\end{array}$ & Vico Mañas & $\begin{array}{c}12^{\mathrm{a}} \\
\text { Câmara } \\
\text { Criminal }\end{array}$ & $30 / 03 / 2011$ \\
\hline A282 & $\begin{array}{l}\text { Agravo em } \\
\text { Execução }\end{array}$ & $\begin{array}{c}0045046- \\
32.2011 .8 .26 .0000\end{array}$ & João Morenghi & $\begin{array}{c}12^{\mathrm{a}} \\
\text { Câmara } \\
\text { Criminal }\end{array}$ & $30 / 11 / 2011$ \\
\hline A283 & $\begin{array}{l}\text { Agravo em } \\
\text { Execução }\end{array}$ & $\begin{array}{c}\text { 064594- } \\
43.2011 .8 .26 .0000\end{array}$ & Breno Guimarães & $\begin{array}{c}12^{\mathrm{a}} \\
\text { Câmara } \\
\text { Criminal }\end{array}$ & $24 / 08 / 2011$ \\
\hline A284 & $\begin{array}{l}\text { Agravo em } \\
\text { Execução }\end{array}$ & $\begin{array}{c}0052918- \\
98.2011 .8 .26 .0000\end{array}$ & Eduardo Pereira & $\begin{array}{c}12^{\mathrm{a}} \\
\text { Câmara } \\
\text { Criminal }\end{array}$ & $28 / 09 / 2011$ \\
\hline A285 & Agravo em & 0117039- & Amable Lopez & $12^{\mathrm{a}}$ & $14 / 12 / 2011$ \\
\hline
\end{tabular}




\begin{tabular}{|c|c|c|c|c|c|}
\hline & Execução & 38.2011 .8 .26 .0000 & Soto & $\begin{array}{l}\text { Câmara } \\
\text { Criminal }\end{array}$ & \\
\hline A286 & $\begin{array}{l}\text { Habeas } \\
\text { Corpus }\end{array}$ & $\begin{array}{c}0160431- \\
91.2012 .8 .26 .0000\end{array}$ & $\begin{array}{c}\text { Amable Lopez } \\
\text { Soto }\end{array}$ & $\begin{array}{c}12^{\mathrm{a}} \\
\text { Câmara } \\
\text { Criminal }\end{array}$ & $26 / 09 / 2012$ \\
\hline A287 & $\begin{array}{l}\text { Agravo em } \\
\text { Execução }\end{array}$ & $\begin{array}{c}0034033- \\
02.2012 .8 .26 .0000\end{array}$ & João Morenghi & $\begin{array}{c}12^{\mathrm{a}} \\
\text { Câmara } \\
\text { Criminal }\end{array}$ & $14 / 11 / 2012$ \\
\hline A288 & $\begin{array}{l}\text { Agravo em } \\
\text { Execução }\end{array}$ & $\begin{array}{c}0195760- \\
67.2012 .8 .26 .0000\end{array}$ & Breno Guimarães & $\begin{array}{c}12^{\mathrm{a}} \\
\text { Câmara } \\
\text { Criminal }\end{array}$ & $12 / 12 / 2012$ \\
\hline A289 & $\begin{array}{l}\text { Agravo em } \\
\text { Execução }\end{array}$ & $\begin{array}{c}0166763- \\
74.2012 .8 .26 .0000\end{array}$ & Vico Mañas & $\begin{array}{c}12^{\mathrm{a}} \\
\text { Câmara } \\
\text { Criminal }\end{array}$ & $17 / 12 / 2012$ \\
\hline A290 & $\begin{array}{l}\text { Agravo em } \\
\text { Execução }\end{array}$ & $\begin{array}{c}0162920- \\
04.2012 .8 .26 .0000\end{array}$ & Paulo Rossi & $\begin{array}{c}12^{\mathrm{a}} \\
\text { Câmara } \\
\text { Criminal }\end{array}$ & $17 / 12 / 2012$ \\
\hline A291 & $\begin{array}{l}\text { Agravo em } \\
\text { Execução }\end{array}$ & $\begin{array}{c}\text { 0041149- } \\
25.2013 .8 .26 .0000\end{array}$ & Vico Mañas & $\begin{array}{c}12^{\mathrm{a}} \\
\text { Câmara } \\
\text { Criminal }\end{array}$ & $05 / 07 / 2013$ \\
\hline A292 & $\begin{array}{l}\text { Agravo em } \\
\text { Execução }\end{array}$ & $\begin{array}{c}0055938- \\
29.2013 .8 .26 .0000\end{array}$ & $\begin{array}{c}\text { Angélica de } \\
\text { Almeida }\end{array}$ & $\begin{array}{c}12^{\mathrm{a}} \\
\text { Câmara } \\
\text { Criminal }\end{array}$ & $31 / 07 / 2013$ \\
\hline A293 & $\begin{array}{l}\text { Agravo em } \\
\text { Execução }\end{array}$ & $\begin{array}{c}0121272- \\
10.2013 .8 .26 .0000\end{array}$ & Breno Guimarães & $\begin{array}{c}12^{\mathrm{a}} \\
\text { Câmara } \\
\text { Criminal }\end{array}$ & $28 / 08 / 2013$ \\
\hline A294 & $\begin{array}{l}\text { Agravo em } \\
\text { Execução }\end{array}$ & $\begin{array}{c}\text { 7003247- } \\
25.2013 .8 .26 .0482\end{array}$ & Paulo Rossi & $\begin{array}{c}12^{\mathrm{a}} \\
\text { Câmara } \\
\text { Criminal }\end{array}$ & 09/10/2013 \\
\hline A295 & $\begin{array}{l}\text { Agravo em } \\
\text { Execução }\end{array}$ & $\begin{array}{c}0175998- \\
31.2013 .8 .26 .0000\end{array}$ & Vico Mañas & $\begin{array}{c}12^{\mathrm{a}} \\
\text { Câmara } \\
\text { Criminal }\end{array}$ & $11 / 12 / 2013$ \\
\hline A296 & Agravo em & 0198065- & João Morenghi & $12^{\mathrm{a}}$ & $17 / 09 / 2014$ \\
\hline
\end{tabular}




\begin{tabular}{|c|c|c|c|c|c|}
\hline & Execução & 87.2013 .8 .26 .0000 & & $\begin{array}{l}\text { Câmara } \\
\text { Criminal }\end{array}$ & \\
\hline A297 & $\begin{array}{l}\text { Agravo em } \\
\text { Execução }\end{array}$ & $\begin{array}{c}7005415- \\
20.2013 .8 .26 .0637\end{array}$ & Vico Mañas & $\begin{array}{c}12^{\mathrm{a}} \\
\text { Câmara } \\
\text { Criminal }\end{array}$ & $03 / 12 / 2014$ \\
\hline A298 & $\begin{array}{l}\text { Agravo em } \\
\text { Execução }\end{array}$ & $\begin{array}{c}\text { 7003360- } \\
\text { 76.2013.8.26.0482 }\end{array}$ & João Morenghi & $\begin{array}{c}12^{\mathrm{a}} \\
\text { Câmara } \\
\text { Criminal }\end{array}$ & $03 / 12 / 2014$ \\
\hline A299 & $\begin{array}{l}\text { Agravo em } \\
\text { Execução }\end{array}$ & $\begin{array}{c}\text { 0069109- } \\
19.2014 .8 .26 .0000\end{array}$ & $\begin{array}{l}\text { Angélica de } \\
\text { Almeida }\end{array}$ & $\begin{array}{c}12^{\mathrm{a}} \\
\text { Câmara } \\
\text { Criminal }\end{array}$ & $10 / 12 / 2014$ \\
\hline A 300 & $\begin{array}{l}\text { Agravo em } \\
\text { Execução }\end{array}$ & $\begin{array}{c}\text { 7003991- } \\
\text { 40.2013.8.26.0637 }\end{array}$ & Paulo Rossi & $\begin{array}{c}12^{\mathrm{a}} \\
\text { Câmara } \\
\text { Criminal }\end{array}$ & $17 / 12 / 2014$ \\
\hline A301 & $\begin{array}{l}\text { Agravo em } \\
\text { Execução }\end{array}$ & $990.10 .400355-5$ & Cardoso Perpétuo & $\begin{array}{c}13^{\mathrm{a}} \\
\text { Câmara } \\
\text { Criminal }\end{array}$ & $09 / 12 / 2010$ \\
\hline A302 & $\begin{array}{l}\text { Agravo em } \\
\text { Execução }\end{array}$ & $990.10 .307204-9$ & Lopes da Silva & $\begin{array}{c}13^{\mathrm{a}} \\
\text { Câmara } \\
\text { Criminal }\end{array}$ & $21 / 10 / 2010$ \\
\hline A303 & $\begin{array}{l}\text { Agravo em } \\
\text { Execução }\end{array}$ & $990.10 .217942-7$ & Renê Ricupero & $\begin{array}{c}13^{\mathrm{a}} \\
\text { Câmara } \\
\text { Criminal }\end{array}$ & $07 / 10 / 2010$ \\
\hline A304 & $\begin{array}{l}\text { Agravo em } \\
\text { Execução }\end{array}$ & $990.10 .255927-0$ & Lopes da Silva & $\begin{array}{c}13^{\mathrm{a}} \\
\text { Câmara } \\
\text { Criminal }\end{array}$ & $30 / 09 / 2010$ \\
\hline A 305 & $\begin{array}{l}\text { Agravo em } \\
\text { Execução }\end{array}$ & $990.10 .290492-0$ & França Carvalho & $\begin{array}{c}13^{\mathrm{a}} \\
\text { Câmara } \\
\text { Criminal }\end{array}$ & $07 / 10 / 2010$ \\
\hline A306 & $\begin{array}{l}\text { Agravo em } \\
\text { Execução }\end{array}$ & $\begin{array}{c}0050277- \\
40.2011 .8 .26 .0000\end{array}$ & $\begin{array}{c}\text { Augusto de } \\
\text { Siqueira }\end{array}$ & $\begin{array}{c}13^{\mathrm{a}} \\
\text { Câmara } \\
\text { Criminal }\end{array}$ & $15 / 12 / 2011$ \\
\hline A307 & Agravo em & 0077287- & Renê Ricupero & $13^{\mathrm{a}}$ & $15 / 09 / 2011$ \\
\hline
\end{tabular}




\begin{tabular}{|c|c|c|c|c|c|}
\hline & Execução & 59.2011.8.26.0000 & & $\begin{array}{l}\text { Câmara } \\
\text { Criminal }\end{array}$ & \\
\hline A308 & $\begin{array}{l}\text { Agravo em } \\
\text { Execução }\end{array}$ & $\begin{array}{c}0037994- \\
82.2011 .8 .26 .0000\end{array}$ & Cardoso Perpétuo & $\begin{array}{c}13^{\mathrm{a}} \\
\text { Câmara } \\
\text { Criminal }\end{array}$ & $06 / 10 / 2011$ \\
\hline A309 & $\begin{array}{l}\text { Agravo em } \\
\text { Execução }\end{array}$ & $\begin{array}{c}0123437- \\
98.2011 .8 .26 .0000\end{array}$ & Cardoso Perpétuo & $\begin{array}{c}13^{\mathrm{a}} \\
\text { Câmara } \\
\text { Criminal }\end{array}$ & $06 / 10 / 2011$ \\
\hline A310 & $\begin{array}{l}\text { Agravo em } \\
\text { Execução }\end{array}$ & $\begin{array}{c}\text { 0152654- } \\
89.2011 .8 .26 .0000\end{array}$ & França Carvalho & $\begin{array}{c}13^{\mathrm{a}} \\
\text { Câmara } \\
\text { Criminal }\end{array}$ & $10 / 11 / 2011$ \\
\hline A311 & $\begin{array}{l}\text { Agravo em } \\
\text { Execução }\end{array}$ & $\begin{array}{c}0139314- \\
44.2012 .8 .26 .0000\end{array}$ & França Carvalho & $\begin{array}{c}13^{\mathrm{a}} \\
\text { Câmara } \\
\text { Criminal }\end{array}$ & 09/11/2012 \\
\hline A312 & $\begin{array}{l}\text { Agravo em } \\
\text { Execução }\end{array}$ & $\begin{array}{c}0166358- \\
38.2012 .8 .26 .0000\end{array}$ & Renê Ricupero & $\begin{array}{c}13^{\mathrm{a}} \\
\text { Câmara } \\
\text { Criminal }\end{array}$ & $29 / 11 / 2012$ \\
\hline A313 & $\begin{array}{l}\text { Agravo em } \\
\text { Execução }\end{array}$ & $\begin{array}{c}0112878- \\
48.2012 .8 .26 .0000\end{array}$ & Mauricio Valala & $\begin{array}{c}13^{\mathrm{a}} \\
\text { Câmara } \\
\text { Criminal }\end{array}$ & $06 / 12 / 2012$ \\
\hline A314 & $\begin{array}{l}\text { Agravo em } \\
\text { Execução }\end{array}$ & $\begin{array}{c}\text { 0211916- } \\
33.2012 .8 .26 .0000\end{array}$ & $\begin{array}{l}\text { Augusto de } \\
\text { Siqueira }\end{array}$ & $\begin{array}{c}13^{\mathrm{a}} \\
\text { Câmara } \\
\text { Criminal }\end{array}$ & $13 / 12 / 2012$ \\
\hline A 315 & $\begin{array}{l}\text { Agravo em } \\
\text { Execução }\end{array}$ & $\begin{array}{c}\text { 0149659- } \\
\text { 69.2012.8.26.0000 }\end{array}$ & Cardoso Perpétuo & $\begin{array}{c}13^{\mathrm{a}} \\
\text { Câmara } \\
\text { Criminal }\end{array}$ & $13 / 12 / 2012$ \\
\hline A316 & $\begin{array}{l}\text { Agravo em } \\
\text { Execução }\end{array}$ & $\begin{array}{c}0148952- \\
67.2013 .8 .26 .0000\end{array}$ & Cardoso Perpétuo & $\begin{array}{c}13^{\mathrm{a}} \\
\text { Câmara } \\
\text { Criminal }\end{array}$ & $26 / 09 / 2013$ \\
\hline A317 & $\begin{array}{l}\text { Agravo em } \\
\text { Execução }\end{array}$ & $\begin{array}{c}0093514- \\
56.2013 .8 .26 .0000\end{array}$ & Renê Ricupero & $\begin{array}{c}13^{\mathrm{a}} \\
\text { Câmara } \\
\text { Criminal }\end{array}$ & $26 / 09 / 2013$ \\
\hline A318 & Agravo em & 0178439- & Laerte Marrone & $13^{\mathrm{a}}$ & $28 / 11 / 2013$ \\
\hline
\end{tabular}




\begin{tabular}{|c|c|c|c|c|c|}
\hline & Execução & 82.2013 .8 .26 .0000 & $\begin{array}{l}\text { de Castro } \\
\text { Sampaio }\end{array}$ & $\begin{array}{l}\text { Câmara } \\
\text { Criminal }\end{array}$ & \\
\hline A319 & $\begin{array}{l}\text { Agravo em } \\
\text { Execução }\end{array}$ & $\begin{array}{c}0154313- \\
65.2013 .8 .26 .0000\end{array}$ & $\begin{array}{l}\text { Augusto de } \\
\text { Siqueira }\end{array}$ & $\begin{array}{c}13^{\mathrm{a}} \\
\text { Câmara } \\
\text { Criminal }\end{array}$ & $28 / 11 / 2013$ \\
\hline A320 & $\begin{array}{l}\text { Agravo em } \\
\text { Execução }\end{array}$ & $\begin{array}{c}\text { 0182736- } \\
35.2013 .8 .26 .0000\end{array}$ & Cardoso Perpétuo & $\begin{array}{c}13^{\mathrm{a}} \\
\text { Câmara } \\
\text { Criminal }\end{array}$ & $12 / 12 / 2013$ \\
\hline A321 & $\begin{array}{l}\text { Agravo em } \\
\text { Execução }\end{array}$ & $\begin{array}{c}\text { 0023856- } \\
\text { 08.2014.8.26.0000 }\end{array}$ & De Paula Santos & $\begin{array}{c}13^{\mathrm{a}} \\
\text { Câmara } \\
\text { Criminal }\end{array}$ & $27 / 11 / 2014$ \\
\hline A322 & $\begin{array}{l}\text { Agravo em } \\
\text { Execução }\end{array}$ & $\begin{array}{c}\text { 0066657- } \\
36.2014 .8 .26 .0000\end{array}$ & Cardoso Perpétuo & $\begin{array}{c}13^{\mathrm{a}} \\
\text { Câmara } \\
\text { Criminal }\end{array}$ & $04 / 12 / 2014$ \\
\hline A323 & $\begin{array}{l}\text { Agravo em } \\
\text { Execução }\end{array}$ & $\begin{array}{c}7008477- \\
14.2014 .8 .26 .0482\end{array}$ & $\begin{array}{c}\text { Augusto de } \\
\text { Siqueira }\end{array}$ & $\begin{array}{c}13^{\mathrm{a}} \\
\text { Câmara } \\
\text { Criminal }\end{array}$ & $19 / 12 / 2014$ \\
\hline A324 & $\begin{array}{l}\text { Habeas } \\
\text { Corpus }\end{array}$ & $\begin{array}{c}2176166- \\
62.2014 .8 .26 .0000\end{array}$ & De Paula Santos & $\begin{array}{c}13^{\mathrm{a}} \\
\text { Câmara } \\
\text { Criminal }\end{array}$ & $18 / 12 / 2014$ \\
\hline A325 & $\begin{array}{l}\text { Agravo em } \\
\text { Execução }\end{array}$ & $\begin{array}{c}0063701- \\
47.2014 .8 .26 .0000\end{array}$ & Renê Ricupero & $\begin{array}{c}13^{\mathrm{a}} \\
\text { Câmara } \\
\text { Criminal }\end{array}$ & $11 / 12 / 2014$ \\
\hline A326 & $\begin{array}{l}\text { Agravo em } \\
\text { Execução }\end{array}$ & $990.09 .318849-0$ & $\begin{array}{c}\text { Fernando Torres } \\
\text { Garcia }\end{array}$ & $\begin{array}{c}14^{\mathrm{a}} \\
\text { Câmara } \\
\text { Criminal }\end{array}$ & $06 / 05 / 2010$ \\
\hline A327 & $\begin{array}{l}\text { Agravo em } \\
\text { Execução }\end{array}$ & $990.10 .182829-4$ & $\begin{array}{c}\text { Fernando Torres } \\
\text { Garcia }\end{array}$ & $\begin{array}{c}14^{\mathrm{a}} \\
\text { Câmara } \\
\text { Criminal }\end{array}$ & $22 / 07 / 2010$ \\
\hline A328 & $\begin{array}{l}\text { Agravo em } \\
\text { Execução }\end{array}$ & $990.10 .125955-9$ & Walter da Silva & $\begin{array}{c}14^{\mathrm{a}} \\
\text { Câmara } \\
\text { Criminal }\end{array}$ & $22 / 07 / 2010$ \\
\hline A329 & Agravo em & 990.10.305593-4 & Walter da Silva & $14^{\mathrm{a}}$ & $07 / 10 / 2010$ \\
\hline
\end{tabular}




\begin{tabular}{|c|c|c|c|c|c|}
\hline & Execução & & & $\begin{array}{l}\text { Câmara } \\
\text { Criminal }\end{array}$ & \\
\hline A330 & $\begin{array}{l}\text { Agravo em } \\
\text { Execução }\end{array}$ & $990.10 .318791-1$ & $\begin{array}{c}\text { Fernando Torres } \\
\text { Garcia }\end{array}$ & $\begin{array}{c}14^{\mathrm{a}} \\
\text { Câmara } \\
\text { Criminal }\end{array}$ & $02 / 12 / 2010$ \\
\hline A331 & $\begin{array}{l}\text { Agravo em } \\
\text { Execução }\end{array}$ & $\begin{array}{c}0121034- \\
59.2011 .8 .26 .0000\end{array}$ & $\begin{array}{c}\text { Fernando Torres } \\
\text { Garcia }\end{array}$ & $\begin{array}{c}14^{\mathrm{a}} \\
\text { Câmara } \\
\text { Criminal }\end{array}$ & $15 / 09 / 2011$ \\
\hline A332 & $\begin{array}{l}\text { Agravo em } \\
\text { Execução }\end{array}$ & $\begin{array}{c}0098598- \\
09.2011 .8 .26 .0000\end{array}$ & $\begin{array}{c}\text { Fernando Torres } \\
\text { Garcia }\end{array}$ & $\begin{array}{c}14^{\mathrm{a}} \\
\text { Câmara } \\
\text { Criminal }\end{array}$ & 06/10/2011 \\
\hline A333 & $\begin{array}{l}\text { Agravo em } \\
\text { Execução }\end{array}$ & $\begin{array}{c}0100618- \\
70.2011 .8 .26 .0000\end{array}$ & Wilson Barreira & $\begin{array}{c}14^{\mathrm{a}} \\
\text { Câmara } \\
\text { Criminal }\end{array}$ & $10 / 11 / 2011$ \\
\hline A334 & $\begin{array}{l}\text { Habeas } \\
\text { Corpus }\end{array}$ & $\begin{array}{c}0243043- \\
23.2011 .8 .26 .0000\end{array}$ & Walter da Silva & $\begin{array}{c}14^{\mathrm{a}} \\
\text { Câmara } \\
\text { Criminal }\end{array}$ & $24 / 11 / 2011$ \\
\hline A335 & $\begin{array}{l}\text { Habeas } \\
\text { Corpus }\end{array}$ & $\begin{array}{c}0060040- \\
65.2011 .8 .26 .0000\end{array}$ & Wilson Barreira & $\begin{array}{c}14^{\mathrm{a}} \\
\text { Câmara } \\
\text { Criminal }\end{array}$ & $15 / 12 / 2011$ \\
\hline A336 & $\begin{array}{l}\text { Agravo em } \\
\text { Execução }\end{array}$ & $\begin{array}{c}0110505- \\
44.2012 .8 .26 .0000\end{array}$ & Wilson Barreira & $\begin{array}{c}14^{\mathrm{a}} \\
\text { Câmara } \\
\text { Criminal }\end{array}$ & $27 / 09 / 2012$ \\
\hline A337 & $\begin{array}{l}\text { Agravo em } \\
\text { Execução }\end{array}$ & $\begin{array}{c}0108023- \\
26.2012 .8 .26 .0000\end{array}$ & Wilson Barreira & $\begin{array}{c}14^{\mathrm{a}} \\
\text { Câmara } \\
\text { Criminal }\end{array}$ & $27 / 09 / 2012$ \\
\hline A338 & $\begin{array}{l}\text { Agravo em } \\
\text { Execução }\end{array}$ & $\begin{array}{c}0181378- \\
69.2012 .8 .26 .0000\end{array}$ & $\begin{array}{c}\text { Fernando Torres } \\
\text { Garcia }\end{array}$ & $\begin{array}{c}14^{\mathrm{a}} \\
\text { Câmara } \\
\text { Criminal }\end{array}$ & $04 / 10 / 2012$ \\
\hline A339 & $\begin{array}{l}\text { Agravo em } \\
\text { Execução }\end{array}$ & $\begin{array}{c}0138313- \\
24.2012 .8 .26 .0000\end{array}$ & Walter da Silva & $\begin{array}{c}14^{\mathrm{a}} \\
\text { Câmara } \\
\text { Criminal }\end{array}$ & $22 / 11 / 2012$ \\
\hline A340 & Agravo em & $0214738-$ & Fernando Torres & $14^{\mathrm{a}}$ & $13 / 12 / 2012$ \\
\hline
\end{tabular}




\begin{tabular}{|c|c|c|c|c|c|}
\hline & Execução & 92.2012 .8 .26 .0000 & Garcia & $\begin{array}{l}\text { Câmara } \\
\text { Criminal }\end{array}$ & \\
\hline A341 & $\begin{array}{l}\text { Habeas } \\
\text { Corpus }\end{array}$ & $\begin{array}{c}0038717- \\
33.2013 .8 .26 .0000\end{array}$ & Marco de Lorenzi & $\begin{array}{c}14^{\mathrm{a}} \\
\text { Câmara } \\
\text { Criminal }\end{array}$ & $20 / 06 / 2013$ \\
\hline A342 & $\begin{array}{l}\text { Agravo em } \\
\text { Execução }\end{array}$ & $\begin{array}{c}0114567- \\
93.2013 .8 .26 .0000\end{array}$ & $\begin{array}{c}\text { Fernando Torres } \\
\text { Garcia }\end{array}$ & $\begin{array}{c}14^{\mathrm{a}} \\
\text { Câmara } \\
\text { Criminal }\end{array}$ & $29 / 08 / 2013$ \\
\hline A343 & $\begin{array}{l}\text { Agravo em } \\
\text { Execução }\end{array}$ & $\begin{array}{c}0141390- \\
07.2013 .8 .26 .0000\end{array}$ & $\begin{array}{c}\text { Miguel Marques e } \\
\text { Silva }\end{array}$ & $\begin{array}{c}14^{\mathrm{a}} \\
\text { Câmara } \\
\text { Criminal }\end{array}$ & $26 / 09 / 2013$ \\
\hline A 344 & $\begin{array}{l}\text { Agravo em } \\
\text { Execução }\end{array}$ & $\begin{array}{c}0118943- \\
25.2013 .8 .26 .0000\end{array}$ & Walter da Silva & $\begin{array}{c}14^{\mathrm{a}} \\
\text { Câmara } \\
\text { Criminal }\end{array}$ & $17 / 10 / 2013$ \\
\hline A 345 & $\begin{array}{l}\text { Agravo em } \\
\text { Execução }\end{array}$ & $\begin{array}{c}0180697- \\
65.2013 .8 .26 .0000\end{array}$ & $\begin{array}{c}\text { Fernando Torres } \\
\text { Garcia }\end{array}$ & $\begin{array}{c}14^{\mathrm{a}} \\
\text { Câmara } \\
\text { Criminal }\end{array}$ & $28 / 10 / 2013$ \\
\hline A346 & $\begin{array}{l}\text { Agravo em } \\
\text { Execução }\end{array}$ & $\begin{array}{c}\text { 7003894- } \\
40.2013 .8 .26 .0637\end{array}$ & Walter da Silva & $\begin{array}{c}14^{\mathrm{a}} \\
\text { Câmara } \\
\text { Criminal }\end{array}$ & $17 / 07 / 2014$ \\
\hline A347 & $\begin{array}{l}\text { Agravo em } \\
\text { Execução }\end{array}$ & $\begin{array}{c}0031822- \\
22.2014 .8 .26 .0000\end{array}$ & $\begin{array}{c}\text { Hermann } \\
\text { Herschander }\end{array}$ & $\begin{array}{c}14^{\mathrm{a}} \\
\text { Câmara } \\
\text { Criminal }\end{array}$ & 07/08/2014 \\
\hline A348 & $\begin{array}{l}\text { Agravo em } \\
\text { Execução }\end{array}$ & $\begin{array}{c}0049708- \\
34.2014 .8 .26 .0000\end{array}$ & $\begin{array}{c}\text { Miguel Marques e } \\
\text { Silva }\end{array}$ & $\begin{array}{c}14^{\mathrm{a}} \\
\text { Câmara } \\
\text { Criminal }\end{array}$ & $06 / 11 / 2014$ \\
\hline A349 & $\begin{array}{l}\text { Agravo em } \\
\text { Execução }\end{array}$ & $\begin{array}{c}0065355- \\
69.2014 .8 .26 .0000\end{array}$ & $\begin{array}{c}\text { Fernando Torres } \\
\text { Garcia }\end{array}$ & $\begin{array}{c}14^{\mathrm{a}} \\
\text { Câmara } \\
\text { Criminal }\end{array}$ & $04 / 12 / 2014$ \\
\hline $\mathrm{A} 350$ & $\begin{array}{l}\text { Agravo em } \\
\text { Execução }\end{array}$ & $\begin{array}{c}\text { 7013887- } \\
87.2013 .8 .26 .0482\end{array}$ & Marco de Lorenzi & $\begin{array}{c}14^{\mathrm{a}} \\
\text { Câmara } \\
\text { Criminal }\end{array}$ & $04 / 12 / 2014$ \\
\hline A351 & Agravo em & $990.09 .315696-2$ & Ribeiro dos & $15^{\mathrm{a}}$ & $04 / 02 / 2010$ \\
\hline
\end{tabular}




\begin{tabular}{|c|c|c|c|c|c|}
\hline & Execução & & Santos & $\begin{array}{l}\text { Câmara } \\
\text { Criminal }\end{array}$ & \\
\hline A352 & $\begin{array}{l}\text { Agravo em } \\
\text { Execução }\end{array}$ & $990.09 .278420-0$ & $\begin{array}{l}\text { Ribeiro dos } \\
\text { Santos }\end{array}$ & $\begin{array}{c}15^{\mathrm{a}} \\
\text { Câmara } \\
\text { Criminal }\end{array}$ & $25 / 03 / 2010$ \\
\hline A353 & $\begin{array}{l}\text { Agravo em } \\
\text { Execução }\end{array}$ & $990.10 .096350-3$ & Camilo Léllis & $\begin{array}{c}15^{\mathrm{a}} \\
\text { Câmara } \\
\text { Criminal }\end{array}$ & $01 / 07 / 2010$ \\
\hline A354 & $\begin{array}{l}\text { Agravo em } \\
\text { Execução }\end{array}$ & $990.10 .167694-0$ & $\begin{array}{c}\text { Ribeiro dos } \\
\text { Santos }\end{array}$ & $\begin{array}{c}15^{\mathrm{a}} \\
\text { Câmara } \\
\text { Criminal }\end{array}$ & 05/08/2010 \\
\hline A355 & $\begin{array}{l}\text { Agravo em } \\
\text { Execução }\end{array}$ & $990.10 .107014-6$ & Camilo Léllis & $\begin{array}{c}15^{\mathrm{a}} \\
\text { Câmara } \\
\text { Criminal }\end{array}$ & $15 / 07 / 2010$ \\
\hline A356 & $\begin{array}{l}\text { Agravo em } \\
\text { Execução }\end{array}$ & $\begin{array}{c}0387027- \\
02.2010 .8 .26 .0000\end{array}$ & Amado de Faria & $\begin{array}{c}15^{\mathrm{a}} \\
\text { Câmara } \\
\text { Criminal }\end{array}$ & $10 / 02 / 2011$ \\
\hline A357 & $\begin{array}{l}\text { Agravo em } \\
\text { Execução }\end{array}$ & $\begin{array}{c}0469531- \\
65.2010 .8 .26 .0000\end{array}$ & $\begin{array}{c}\text { Ribeiro dos } \\
\text { Santos }\end{array}$ & $\begin{array}{c}15^{\mathrm{a}} \\
\text { Câmara } \\
\text { Criminal }\end{array}$ & $28 / 04 / 2011$ \\
\hline A 358 & $\begin{array}{l}\text { Agravo em } \\
\text { Execução }\end{array}$ & $\begin{array}{c}\text { 0046176- } \\
57.2011 .8 .26 .0000\end{array}$ & Poças Leitão & $\begin{array}{c}15^{\mathrm{a}} \\
\text { Câmara } \\
\text { Criminal }\end{array}$ & $25 / 08 / 2011$ \\
\hline A359 & $\begin{array}{l}\text { Agravo em } \\
\text { Execução }\end{array}$ & $\begin{array}{c}0138192- \\
30.2011 .8 .26 .0000\end{array}$ & $\begin{array}{c}\text { Ribeiro dos } \\
\text { Santos }\end{array}$ & $\begin{array}{c}15^{\mathrm{a}} \\
\text { Câmara } \\
\text { Criminal }\end{array}$ & 06/10/2011 \\
\hline A360 & $\begin{array}{l}\text { Agravo em } \\
\text { Execução }\end{array}$ & $\begin{array}{c}0075030- \\
61.2011 .8 .26 .0000\end{array}$ & Camilo Léllis & $\begin{array}{c}15^{\mathrm{a}} \\
\text { Câmara } \\
\text { Criminal }\end{array}$ & $10 / 11 / 2011$ \\
\hline A361 & $\begin{array}{l}\text { Agravo em } \\
\text { Execução }\end{array}$ & $\begin{array}{c}\text { 0105099- } \\
\text { 42.2012.8.26.0000 }\end{array}$ & $\begin{array}{c}\text { Ribeiro dos } \\
\text { Santos }\end{array}$ & $\begin{array}{c}15^{\mathrm{a}} \\
\text { Câmara } \\
\text { Criminal }\end{array}$ & $30 / 08 / 2012$ \\
\hline A362 & Agravo em & $0205142-$ & Poças Leitão & $15^{\mathrm{a}}$ & $29 / 11 / 2012$ \\
\hline
\end{tabular}




\begin{tabular}{|c|c|c|c|c|c|}
\hline & Execução & 84.2012 .8 .26 .0000 & & $\begin{array}{l}\text { Câmara } \\
\text { Criminal }\end{array}$ & \\
\hline A363 & $\begin{array}{l}\text { Agravo em } \\
\text { Execução }\end{array}$ & $\begin{array}{c}0137122- \\
41.2012 .8 .26 .0000\end{array}$ & $\begin{array}{l}\text { Walter de } \\
\text { Almeida } \\
\text { Guilherme }\end{array}$ & $\begin{array}{c}15^{\mathrm{a}} \\
\text { Câmara } \\
\text { Criminal }\end{array}$ & $06 / 12 / 2012$ \\
\hline A364 & $\begin{array}{l}\text { Agravo em } \\
\text { Execução }\end{array}$ & $\begin{array}{c}\text { 0246931- } \\
97.2011 .8 .26 .0000\end{array}$ & J. Martins & $\begin{array}{c}15^{\mathrm{a}} \\
\text { Câmara } \\
\text { Criminal }\end{array}$ & $10 / 05 / 2012$ \\
\hline A365 & $\begin{array}{l}\text { Agravo em } \\
\text { Execução }\end{array}$ & $\begin{array}{c}0238733- \\
71.2011 .8 .26 .0000\end{array}$ & $\begin{array}{c}\text { Ribeiro dos } \\
\text { Santos }\end{array}$ & $\begin{array}{c}15^{\mathrm{a}} \\
\text { Câmara } \\
\text { Criminal }\end{array}$ & 08/03/2012 \\
\hline A366 & $\begin{array}{l}\text { Agravo em } \\
\text { Execução }\end{array}$ & $\begin{array}{c}0046790- \\
91.2013 .8 .26 .0000\end{array}$ & $\begin{array}{l}\text { Walter de } \\
\text { Almeida } \\
\text { Guilherme }\end{array}$ & $\begin{array}{c}15^{\mathrm{a}} \\
\text { Câmara } \\
\text { Criminal }\end{array}$ & 08/08/2013 \\
\hline A367 & $\begin{array}{l}\text { Agravo em } \\
\text { Execução }\end{array}$ & $\begin{array}{c}0170353- \\
25.2013 .8 .26 .0000\end{array}$ & Poças Leitão & $\begin{array}{c}15^{\mathrm{a}} \\
\text { Câmara } \\
\text { Criminal }\end{array}$ & $24 / 10 / 2013$ \\
\hline A368 & $\begin{array}{l}\text { Agravo em } \\
\text { Execução }\end{array}$ & $\begin{array}{c}0173455- \\
55.2013 .8 .26 .0000\end{array}$ & Encinas Manfré & $\begin{array}{c}15^{\mathrm{a}} \\
\text { Câmara } \\
\text { Criminal }\end{array}$ & $05 / 12 / 2013$ \\
\hline A369 & $\begin{array}{l}\text { Agravo em } \\
\text { Execução }\end{array}$ & $\begin{array}{c}0177281- \\
89.2013 .8 .26 .0000\end{array}$ & De Paula Santos & $\begin{array}{c}15^{\mathrm{a}} \\
\text { Câmara } \\
\text { Criminal }\end{array}$ & $12 / 12 / 2013$ \\
\hline A 370 & $\begin{array}{l}\text { Agravo em } \\
\text { Execução }\end{array}$ & $\begin{array}{c}\text { 0185407- } \\
31.2013 .8 .26 .0000\end{array}$ & $\begin{array}{c}\text { Nelson Fonseca } \\
\text { Junior }\end{array}$ & $\begin{array}{c}15^{\mathrm{a}} \\
\text { Câmara } \\
\text { Criminal }\end{array}$ & $12 / 12 / 2013$ \\
\hline A371 & $\begin{array}{l}\text { Agravo em } \\
\text { Execução }\end{array}$ & $\begin{array}{c}0012015- \\
16.2014 .8 .26 .0000\end{array}$ & $\begin{array}{l}\text { Guilherme de } \\
\text { Souza Nucci }\end{array}$ & $\begin{array}{c}15^{\mathrm{a}} \\
\text { Câmara } \\
\text { Criminal }\end{array}$ & $07 / 08 / 2014$ \\
\hline A372 & $\begin{array}{l}\text { Agravo em } \\
\text { Execução }\end{array}$ & $\begin{array}{c}0037804- \\
17.2014 .8 .26 .0000\end{array}$ & $\begin{array}{l}\text { Walter de } \\
\text { Almeida } \\
\text { Guilherme }\end{array}$ & $\begin{array}{c}15^{\mathrm{a}} \\
\text { Câmara } \\
\text { Criminal }\end{array}$ & $18 / 09 / 2014$ \\
\hline A373 & Agravo em & 0048794- & Poças Leitão & $15^{\mathrm{a}}$ & $25 / 09 / 2014$ \\
\hline
\end{tabular}




\begin{tabular}{|c|c|c|c|c|c|}
\hline & Execução & 67.2014.8.26.0000 & & $\begin{array}{l}\text { Câmara } \\
\text { Criminal }\end{array}$ & \\
\hline A 374 & $\begin{array}{l}\text { Agravo em } \\
\text { Execução }\end{array}$ & $\begin{array}{c}\text { 0050856- } \\
80.2014 .8 .26 .0000\end{array}$ & $\begin{array}{c}\text { Sérgio Manzina } \\
\text { Martins }\end{array}$ & $\begin{array}{c}15^{\mathrm{a}} \\
\text { Câmara } \\
\text { Criminal }\end{array}$ & $06 / 11 / 2014$ \\
\hline A375 & $\begin{array}{l}\text { Agravo em } \\
\text { Execução }\end{array}$ & $\begin{array}{c}7000298- \\
20.2014 .8 .26 .0344\end{array}$ & $\begin{array}{c}\text { Ricardo Sale } \\
\text { Junior }\end{array}$ & $\begin{array}{c}15^{\mathrm{a}} \\
\text { Câmara } \\
\text { Criminal }\end{array}$ & $04 / 12 / 2014$ \\
\hline A 376 & $\begin{array}{l}\text { Agravo em } \\
\text { Execução }\end{array}$ & $990.09 .061170-7$ & Almeida Toledo & $\begin{array}{c}16^{\mathrm{a}} \\
\text { Câmara } \\
\text { Criminal }\end{array}$ & $28 / 09 / 2010$ \\
\hline A 377 & $\begin{array}{l}\text { Agravo em } \\
\text { Execução }\end{array}$ & $990.10 .187689-2$ & $\begin{array}{c}\text { Alberto Mariz de } \\
\text { Oliveira }\end{array}$ & $\begin{array}{c}16^{\mathrm{a}} \\
\text { Câmara } \\
\text { Criminal }\end{array}$ & 05/10/2010 \\
\hline A378 & $\begin{array}{l}\text { Agravo em } \\
\text { Execução }\end{array}$ & $990.10 .384154-9$ & Newton Neves & $\begin{array}{c}16^{\mathrm{a}} \\
\text { Câmara } \\
\text { Criminal }\end{array}$ & $30 / 11 / 2010$ \\
\hline A379 & $\begin{array}{l}\text { Agravo em } \\
\text { Execução }\end{array}$ & $990.10 .052161-6$ & Pedro Menin & $\begin{array}{c}16^{\mathrm{a}} \\
\text { Câmara } \\
\text { Criminal }\end{array}$ & $07 / 12 / 2010$ \\
\hline A380 & $\begin{array}{l}\text { Agravo em } \\
\text { Execução }\end{array}$ & $990.10 .415990-3$ & Borges Pereira & $\begin{array}{c}16^{\mathrm{a}} \\
\text { Câmara } \\
\text { Criminal }\end{array}$ & $14 / 12 / 2010$ \\
\hline A381 & $\begin{array}{l}\text { Agravo em } \\
\text { Execução }\end{array}$ & $\begin{array}{c}0155108- \\
42.2011 .8 .26 .0000\end{array}$ & Pedro Menin & $\begin{array}{c}16^{\mathrm{a}} \\
\text { Câmara } \\
\text { Criminal }\end{array}$ & $08 / 11 / 2011$ \\
\hline A382 & $\begin{array}{l}\text { Agravo em } \\
\text { Execução }\end{array}$ & $\begin{array}{c}\text { 0043482- } \\
18.2011 .8 .26 .0000\end{array}$ & Souza Nucci & $\begin{array}{c}16^{\mathrm{a}} \\
\text { Câmara } \\
\text { Criminal }\end{array}$ & $20 / 09 / 2011$ \\
\hline A383 & $\begin{array}{l}\text { Agravo em } \\
\text { Execução }\end{array}$ & $\begin{array}{c}\text { 0335547- } \\
82.2010 .8 .26 .0000\end{array}$ & $\begin{array}{c}\text { Alberto Mariz de } \\
\text { Oliveira }\end{array}$ & $\begin{array}{c}16^{\mathrm{a}} \\
\text { Câmara } \\
\text { Criminal }\end{array}$ & $22 / 11 / 2011$ \\
\hline
\end{tabular}




\begin{tabular}{|c|c|c|c|c|c|}
\hline A384 & $\begin{array}{l}\text { Agravo em } \\
\text { Execução }\end{array}$ & $\begin{array}{c}\text { 0206894- } \\
28.2011 .8 .26 .0000\end{array}$ & Borges Pereira & $\begin{array}{c}16^{\mathrm{a}} \\
\text { Câmara } \\
\text { Criminal }\end{array}$ & $13 / 12 / 2011$ \\
\hline A 385 & $\begin{array}{l}\text { Agravo em } \\
\text { Execução }\end{array}$ & $\begin{array}{c}0197788- \\
42.2011 .8 .26 .0000\end{array}$ & Almeida Toledo & $\begin{array}{c}16^{\mathrm{a}} \\
\text { Câmara } \\
\text { Criminal }\end{array}$ & $13 / 12 / 2011$ \\
\hline A386 & $\begin{array}{l}\text { Agravo em } \\
\text { Execução }\end{array}$ & $\begin{array}{c}0092648- \\
82.2012 .8 .26 .0000\end{array}$ & Borges Pereira & $\begin{array}{c}16^{\mathrm{a}} \\
\text { Câmara } \\
\text { Criminal }\end{array}$ & $11 / 12 / 2012$ \\
\hline A387 & $\begin{array}{l}\text { Agravo em } \\
\text { Execução }\end{array}$ & $\begin{array}{c}0106795- \\
16.2012 .8 .26 .0000\end{array}$ & Newton Neves & $\begin{array}{c}16^{\mathrm{a}} \\
\text { Câmara } \\
\text { Criminal }\end{array}$ & $13 / 11 / 2012$ \\
\hline A388 & $\begin{array}{l}\text { Agravo em } \\
\text { Execução }\end{array}$ & $\begin{array}{c}0167172- \\
50.2012 .8 .26 .0000\end{array}$ & Pedro Menin & $\begin{array}{c}16^{\mathrm{a}} \\
\text { Câmara } \\
\text { Criminal }\end{array}$ & $04 / 12 / 2012$ \\
\hline A389 & $\begin{array}{l}\text { Agravo em } \\
\text { Execução }\end{array}$ & $\begin{array}{c}0574458- \\
82.2010 .8 .26 .0000\end{array}$ & $\begin{array}{c}\text { Alberto Mariz de } \\
\text { Oliveira }\end{array}$ & $\begin{array}{c}16^{\mathrm{a}} \\
\text { Câmara } \\
\text { Criminal }\end{array}$ & $11 / 12 / 2012$ \\
\hline A390 & $\begin{array}{l}\text { Agravo em } \\
\text { Execução }\end{array}$ & $\begin{array}{c}0121222- \\
52.2011 .8 .26 .0000\end{array}$ & $\begin{array}{c}\text { Otávio de } \\
\text { Almeida Toledo }\end{array}$ & $\begin{array}{c}16^{\mathrm{a}} \\
\text { Câmara } \\
\text { Criminal }\end{array}$ & $18 / 12 / 2012$ \\
\hline A391 & $\begin{array}{l}\text { Agravo em } \\
\text { Execução }\end{array}$ & $\begin{array}{c}0154291- \\
07.2013 .8 .26 .0000\end{array}$ & Borges Pereira & $\begin{array}{c}16^{\mathrm{a}} \\
\text { Câmara } \\
\text { Criminal }\end{array}$ & $22 / 10 / 2013$ \\
\hline A392 & $\begin{array}{l}\text { Agravo em } \\
\text { Execução }\end{array}$ & $\begin{array}{c}0167175- \\
68.2013 .8 .26 .0000\end{array}$ & Newton Neves & $\begin{array}{c}16^{\mathrm{a}} \\
\text { Câmara } \\
\text { Criminal }\end{array}$ & $05 / 11 / 2013$ \\
\hline A393 & $\begin{array}{l}\text { Agravo em } \\
\text { Execução }\end{array}$ & $\begin{array}{c}0182373- \\
48.2013 .8 .26 .0000\end{array}$ & Borges Pereira & $\begin{array}{c}16^{\mathrm{a}} \\
\text { Câmara } \\
\text { Criminal }\end{array}$ & $10 / 12 / 2013$ \\
\hline A394 & $\begin{array}{l}\text { Agravo em } \\
\text { Execução }\end{array}$ & $\begin{array}{c}0125723- \\
78.2013 .8 .26 .0000\end{array}$ & $\begin{array}{c}\text { Alberto Mariz de } \\
\text { Oliveira }\end{array}$ & $\begin{array}{c}16^{\mathrm{a}} \\
\text { Câmara } \\
\text { Criminal }\end{array}$ & $17 / 12 / 2013$ \\
\hline
\end{tabular}




\begin{tabular}{|c|c|c|c|c|c|}
\hline A395 & $\begin{array}{l}\text { Agravo em } \\
\text { Execução }\end{array}$ & $\begin{array}{c}0190201- \\
95.2013 .8 .26 .0000\end{array}$ & Pedro Menin & $\begin{array}{c}16^{\mathrm{a}} \\
\text { Câmara } \\
\text { Criminal }\end{array}$ & $17 / 12 / 2013$ \\
\hline A396 & $\begin{array}{l}\text { Agravo em } \\
\text { Execução }\end{array}$ & $\begin{array}{c}0049733- \\
47.2014 .8 .26 .0000\end{array}$ & Newton Neves & $\begin{array}{c}16^{\mathrm{a}} \\
\text { Câmara } \\
\text { Criminal }\end{array}$ & $23 / 09 / 2014$ \\
\hline A397 & $\begin{array}{l}\text { Agravo em } \\
\text { Execução }\end{array}$ & $\begin{array}{c}\text { 0093105- } \\
80.2013 .8 .26 .0000\end{array}$ & $\begin{array}{c}\text { Alberto Mariz de } \\
\text { Oliveira }\end{array}$ & $\begin{array}{c}16^{\mathrm{a}} \\
\text { Câmara } \\
\text { Criminal }\end{array}$ & $14 / 10 / 2014$ \\
\hline A398 & $\begin{array}{l}\text { Agravo em } \\
\text { Execução }\end{array}$ & $\begin{array}{c}0061923- \\
42.2014 .8 .26 .0000\end{array}$ & $\begin{array}{c}\text { Otávio de } \\
\text { Almeida Toledo }\end{array}$ & $\begin{array}{c}16^{\mathrm{a}} \\
\text { Câmara } \\
\text { Criminal }\end{array}$ & $18 / 11 / 2014$ \\
\hline A399 & $\begin{array}{l}\text { Agravo em } \\
\text { Execução }\end{array}$ & $\begin{array}{c}0054518- \\
52.2014 .8 .26 .0000\end{array}$ & Borges Pereira & $\begin{array}{c}16^{\mathrm{a}} \\
\text { Câmara } \\
\text { Criminal }\end{array}$ & $09 / 12 / 2014$ \\
\hline A400 & $\begin{array}{l}\text { Agravo em } \\
\text { Execução }\end{array}$ & $\begin{array}{c}\text { 0053966- } \\
87.2014 .8 .26 .0000\end{array}$ & $\begin{array}{l}\text { Guilherme de } \\
\text { Souza Nucci }\end{array}$ & $\begin{array}{c}16^{\mathrm{a}} \\
\text { Câmara } \\
\text { Criminal }\end{array}$ & $02 / 12 / 2014$ \\
\hline
\end{tabular}




\section{APÊNDICE B: FICHA DE LEITURA DE ACÓRDÃO}

Dados do processo

\begin{tabular}{|l|l|}
\hline Número do Processo \\
\hline Tipo de ação \\
\hline Desembargador \\
\hline Relator/Câmara \\
\hline Data do julgamento \\
\hline Ementa \\
\hline Julgamento (V.U., \\
\hline maioria etc) \\
\hline Divergência (se houver) \\
\hline Agravante/Paciente \\
\hline Agravado/Autoridade \\
\hline coatora
\end{tabular}

Dados da origem

Decisão $1^{a}$ instância

Pedido formulado

Benefício/Direito da execução

Linhas argumentativas do acórdão

\begin{tabular}{l} 
Dados da execução do \\
sentenciado/Cabimento \\
HC \\
Ressocialização - para \\
manter preso ou para \\
soltar? \\
\hline Discurso da \\
\hline
\end{tabular}




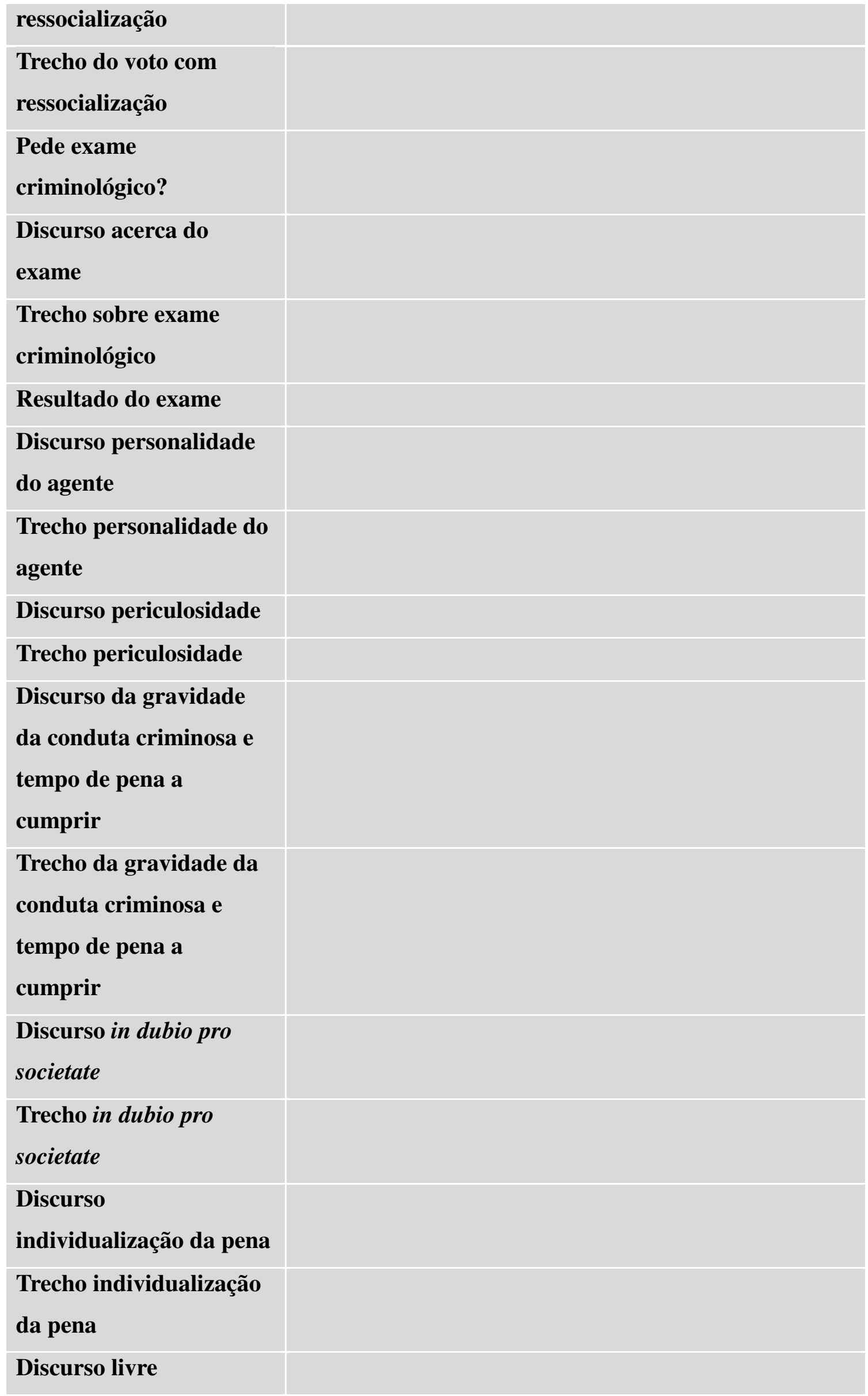




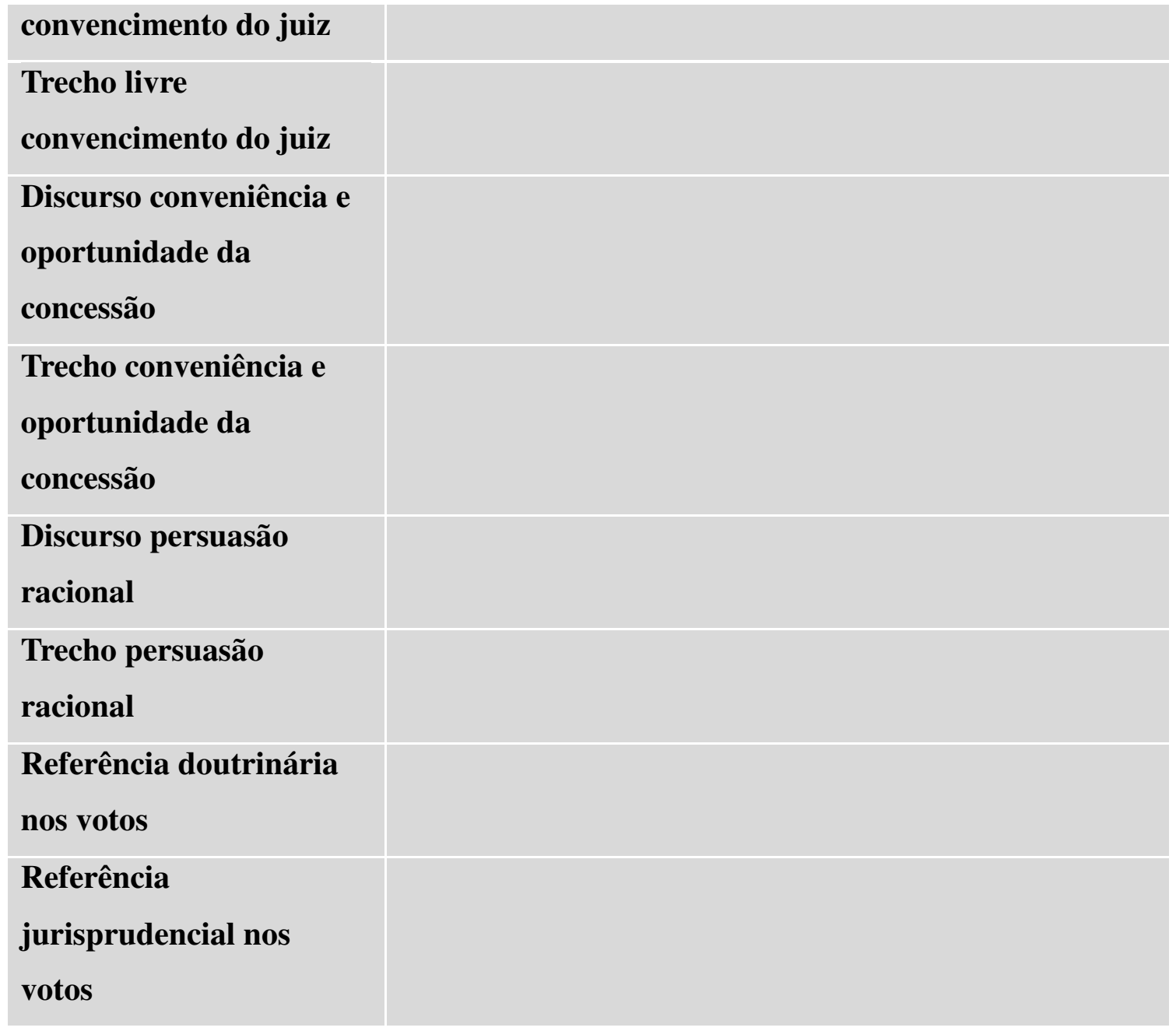

